\title{
Contextualizing Staffage in Nineteenth-Century Canadian Expeditionary
} Photography: $1858-1890$

\author{
By \\ Colette E. Boisvert \\ B.A. Hons., Queen's University \\ A thesis submitted to the \\ Faculty of Graduate Studies and Research \\ in partial fulfillment of the requirements for the degree of \\ Master of Arts \\ in Canadian Art History
}

Carleton University

OTTAWA, Ontario

January 7, 2000

Colette E. Boisvert 
National Library

of Canada

Acquisitions and Bibliographic Services

395 Wellington Street

Ottawa ON K1A ON4

Canada
Bibliothèque nationale

du Canada

Acquisitions et services bibliographiques

395 , rue Wellington

Ottawa ON K1A ON4

Canada
The author has granted a nonexclusive licence allowing the National Library of Canada to reproduce, loan, distribute or sell copies of this thesis in microform, paper or electronic formats.
L'auteur a accordé une licence non exclusive permettant à la Bibliothèque nationale du Canada de reproduire, prêter, distribuer ou vendre des copies de cette thèse sous la forme de microfiche/film, de reproduction sur papier ou sur format électronique.

The author retains ownership of the copyright in this thesis. Neither the thesis nor substantial extracts from it may be printed or otherwise reproduced without the author's permission.
L'auteur conserve la propriété du droit d'auteur qui protège cette thèse. Ni la thèse ni des extraits substantiels de celle-ci ne doivent être imprimés ou autrement reproduits sans son autorisation. 


\begin{abstract}
This thesis will contextualize the use of staffage in nineteenth-century photography in Canada, focusing specifically, but not exclusively, on exploration photographs taken during survey expeditions into Canada's interior. Commonly manifesting in landscapes as a documentary tool, staffage was used to explain more fully the scale and purpose of the place that had been photographed. However, the complexity of photography during this period demanded that figures were situated in front of the lens deliberately with the explicit intention of establishing a human presence, and the large number of inhabited landscapes photographed demonstrate that this was an accepted convention. Further, during this period of territorial expansion, fostered by European imperialist policies and attitudes, staffage established a human presence in what were perceived to be uninhabited, uncivilized tracts of land, verifying occupation and possibly even providing evidence of ownership. Staffage then, was not merely a device used to indicate scale; it was used to create meaning, affecting how the photograph was read.
\end{abstract}

Therefore, it is the purpose of this thesis to demonstrate the connection between the imperialist project and the use of staffage in nineteenth-century British North American expedition photographs through an examination of prevailing attitudes towards possession of land, settlement of the Northwest, and imperialism. Issues regarding the practice of "mapping" in explorations, the technical nature of photography, the ideological construction of nature and landscape, and the role of photography in documenting exploration will all be considered. 


\section{Acknowledgments}

Of course, no thesis is done alone. In particular, I would like to thank my parents who opened up their home to me while I was exercising my brain. To my mother, who kept me sane, and warm, with all those lovely mugs of mulled cranberry; and to my father, who kept encouraging me to get it done-even when I didn't want to hear it.

I would also like to thank Allison Bryndza and Margaret Colwin, my co-workers at the Telesat Canada Corporate Library, for all their help in hunting down articles, and for being patient with me while my attention was "elsewhere." My supervisor, Patricia Kube, also has my everlasting gratitude; her efforts on my behalf are the primary reason why I was finally able to finish writing this.

Dr. Lily Koltun of the National Archives of Canada also deserves credit, as it was her wonderful class that provided one of the primary catalyst for this thesis. Her enthusiasm for my idea was truly heartening.

And lastly, I need to thank my advisor, Carol Payne, for her unrelenting aid and support, and for always reminding me that "the end was in sight," even when it was still far off on the horizon. 


\section{Table of Contents}

List of Illustrations

Introduction: Contextualizing Staffage in Nineteenth-Century Canadian Expeditionary Photography: 1858-1890

i. Defining "Staffage" 4

ii. Positivism and Photography 8

iii. Defining "Landscape" 12

iv. A Question Posed 15

v. Landscape and Staffage: A Discussion of the Literature 18

vi. Establishing a Path 22

I. Establishing a Presence in the Land: Imperialism, Canada, and the West 26

i. The Age of Innocence: British Imperialism 26

ii. The Ties That Bind: Canada and Imperialism 34

iii. "We" Stand Here: Asserting Ownership Through Staffage 43

iv. Imperial Landscapes: Using Staffage to Stake a Claim 50

$\begin{array}{ll}\text { v. In Summary... } & 58\end{array}$

II. From Wasteland to Breadbasket: Geography, Photography, and the Northwest $\quad 60$

i. Conceptions of the Northwest: Obstacles to Settlement 60

ii. Reconsiderations of the Northwest 71

iii. Imperialism's Handmaid: Geography $\quad 79$

iv. Geography's Handmaid: Photography 83

v. Penetrating the Interior at Last-With Camera in Hand 88

vi. Imperial Landscapes: Staffage in Photographs of the West 99

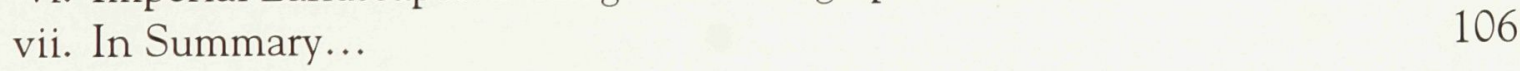

III. Photography in the Field: Technical Consequences and Photographic Authority

i. The Camera Abroad 109

ii. Experiences in the Field: Mosquitoes and Locusts and Rain 116

iii. The Reality of Peopled Landscapes 120 
iv. Photographic Authority: Concept of the Documentary

v. The Photograph Abroad: Disseminating Images

vi. In Summary...

Conclusion: Windows and Mirrors: "Reflections" on Staffage

Illustrations

Bibliography 
13. Diagram of Palliser's Triangle and Fertile Belt. From D. Owram, The Promise of Eden, (Toronto, 2nd ed., 1992), no page number.

14. Diagram of the Oregon Boundary Dispute, 1825-46. From Essays on the Historical Geography of the Canadian West, L.A. Rosenvall et al., eds. (Calgary, 1987), 5.

15. Forest Scene on North Thompson River, 165 Miles Above Kamloops, BC, Benjamin Baltzly, September 20, 1871. From the Sir Sandford Fleming Collection, National Archives of Canada, PA-22606.

16. Geological Survey Camp on the North Thompson River, 165 Miles Above Kamloops, Benjamin Baltzly, September 20-24, 1871. From Andrew Birrell, Photographs and Journal of an Expedition Through British Columbia, 1871 (Toronto, 1978), no page number.

17. Souris River, Corps of Royal Engineers, 1873. From the North American Boundary Commission Collection, National Archives of Canada, C-020289.

18. Fort Ellice, Beaver Creek, Humphrey Lloyd Hime, July 11, 1858. From the Humphrey Lloyd Hime Collection, National Archives of Canada, C-004578.

19. The Hoodoos, Natural Monuments, Banff, William Hanson Boorne, undated [188589]. From Jackson, 44.

20. From the West Shore of Lake Tatla Looking Across Towards Mountain Range Between Tatla and Ominica, BC, Charles Horetzky, 1879. From the Sir Sandford Fleming Collection, National Archives of Canada, PA-022535.

21. Group at Prospect Point, Niagara Falls, Platt D. Babbitt, 1853. From Greenhill and Birrell, no page number.

22. The Prairie Looking West in Henry Youle Hind, Narrative of the Canadian Red River Exploring Expedition of 1857 and of the Assiniboine and Saskatchewan Exploring Expedition of 1858 (London, 1st vol. 1860), no page number. 


\section{Contextualizing Staffage in Nineteenth-Century Canadian Expeditionary Photography: 1858-1890}

Numerous landscape photographs in nineteenth-century photography have an essential characteristic in common: they are inhabited. Spanning various types of subjects and views, small figures_-termed staffage figures — can regularly be found engaged in any number of activities. Men in bowlers can be seen fishing by a river, or sketching a mountain landscape. Women with parasols pose by the Great Pyramids of Egypt, or enjoy a picnic in a bucolic lakeside glade. Native figures sit amongst grasses while a train rests on its tracks in the distance. An engineer can be seen standing on a newly constructed suspension bridge, and soldiers appear amid tents and wagons enjoying a break from their travels. Such figures dot many landscape photographs taken in seemingly distant and foreign wildernesses.

Tourist photographs are probably the most common site for the use of staffage. They include simple shots of individuals displaying themselves to the camera, standing beside their homes or in gardens, or even perhaps beside a famous monument. Regardless of location, the purpose of these figures remains relatively consistent: they act as records, corroborating that at some time they were actually in these locations. Staffage is the visual equivalent of proclaiming someone was here. As these photographs were generally taken abroad and displayed at home, substantiating proof was a necessity that continues to be practised to this day. 
However, staffage is also quite prevalent in another type of photograph: the expedition image. In photographs of locales virtually throughout the world, small figures can be seen taking measurements in vast landscapes, sitting around campfires, posing with horses on mountain trails, waiting by rivers with loaded canoes, leaning against unusual geological formations, or simply standing in an apparently empty plain. They are particularly common in images dating from the nineteenth century, a time of great territorial expansion by European imperial nations, continuing the heritage of exploration and conquest from Columbus and before. The latter half of this century witnessed an acceleration of this process world-wide. France obtained Indochina (present day Vietnam, Cambodia, and Laos); Great Britain expanded from India into the Punjab (a region of Pakistan and northwest India) and Burma (now known as Myanmar); the United States procured the Philippines from Spain; and all of Europe scrambled for control of Africa. ${ }^{1}$ British North America, lacking the military resources necessary for external conquest still participated in expansionist ambitions, turning its attention to the immense and virtually unexplored interior. By the mid-nineteenth century, several exploratory expeditions had been sent by the British government into the "Northwest," even though this area would continue to be under the jurisdiction of the Hudson's Bay Company until 1858.

If in tourist photographs staffage figures indicate proof of presence, what are the implications of staffage figures in expedition photographs? Or, to put it another way, how did staffage affect contemporary interpretations of landscapes that were usually perceived

\footnotetext{
${ }^{1}$ Melinda Corey and George Ochoa, The Encyclopedia of the Victorian World (New York, 1996), 230.
} 
to be uninhabited, uncivilized tracts of land? The tremendous number of populated landscape images during the nineteenth century implies that staffage was an accepted convention-people were put in front of the lens intentionally with the explicit aim of establishing a human presence in the landscape. This was, after all, a traditional means of providing scale. Or staffage could have been used to create a type of tableau known to Victorian audiences, and therefore create a scene that would seem more familiar to them. However, in the case of expedition photographs, the implications of imperial powers inserting themselves into landscapes believed to be wildernesses, both in terms of degree of civilization and in usage, seems to go beyond merely "establishing a presence." Expansionists' intentions may have been the same-to furnish a sense of scale and to render the unknown known-but the consequences of applying this device seem to have been altered. More than merely documenting a place where they have been, staffage in these cases almost demonstrates occupancy of the land, providing a record of residency. Photographed in remote locations of the world, circulated and viewed at home, these figures possibly even provide evidence of ownership of areas where imperial nations had asserted themselves.

This thesis, then, will aim to demonstrate the connection between the imperialist mode of territorial acquisition and the use of staffage in Canadian expeditionary photographs taken between 1858 and 1890 . By establishing a historical context detailing how Canada and its interest in the Northwest worked in tandem with current ideological trends, it will be demonstrated how peopled landscape photographs of this region supported preconceptions about its ownership, as well as its role within colonial rhetoric. 
The intent is to show that staffage, although small and often overlooked, is capable of aiding in the ideological encoding of a photograph.

\section{Defining "Staffage"}

Staffage, although performing diverse roles, is generally characterized as the representation of people on a small scale in relation to the whole of a composition. Its most common manifestation had a direct documentary implication—as it was particularly prevalent in, but not exclusively-to topographic art and artists. Staffage provided the viewer with information regarding scale, population, costume, and daily activities of locals and locations throughout the world, both close and remote. In other words, staffage could be used to explain more fully the purpose of a place by acting as visual cues for the viewer. Nonetheless, staffage functioned on other levels as well. Figures could be added to give visual interest, to aid in the creation of a picturesque setting, to act as repoussoir elements, or to create a narrative subtext. ${ }^{2}$ The profusion of figures in landscape photographs seems to illustrate the convention that photographers defined nature in relation to humanity. ${ }^{3}$ Landscapes were more than framed views of nature; they were used to show the presence of the Creator, or to present a parcel of land owned by an individual, or to illustrate the impact of humanity on an area. Nature and humanity were inextricably linked, and peopled landscapes served to reinforce this cultural preconception.

\footnotetext{
${ }^{2}$ Christine Boyanoski, Staffage to Centre Stage (Toronto, 1989), $2-6$.

${ }^{3}$ Weston J. Naef and James N. Wood, Era of Exploration (New York, 1975), 15.
} 
The clearest way to demonstrate how staffage operates is by contrast. A comparison between J.R. Connon's Group at Elora Gorge, Ontario (fig. 1) of 1895 and Alexander Henderson's Ice Cone, Montmorency Falls (fig. 2) taken in 1876, for example, illustrates the distinction between simple figural views and staffage. In the first photograph, we are presented with a group of ladies and gentleman perched among the rocks beside a riverbed with a cliff wall rising behind them. The second photograph is a winter scene showing a large mound of snow in front of a waterfall, and all the surrounding forms have been encrusted with ice. The apparent progression of a figure down this "ice cone" is of secondary consideration.

In Connon's work, the figures themselves are the focus of the photograph given their proximity to the camera, and the fact that the grouping takes prominence over the surrounding natural forms. Composition within the photograph was determined by the placement of the figures; the landscape here merely provides a backdrop to what is essentially a group portrait. In contrast, in Henderson's photograph, the landscape dominates; the proportionately small figures accentuate its grand scale. The focus here is on the remarkable winter occurrence of an "ice cone" formed by the build-up of spray from Montmorency Falls in Québec. Although small, they do serve a purpose. Staffage, in this case, is used to illustrate the magnitude of the unusual natural phenomenon.

In Staffage to Centre Stage, Christine Boyanoski provides what is perhaps one of the clearest definitions of staffage to date. ${ }^{4}$ She argues, however, that while staffage may

\footnotetext{
${ }^{4}$ See Boyanoski, Staffage to Centre Stage. The title of this work actually marks the focus of an exhibition at the Art Gallery of Ontario, but does not reflect a re-interpretation of staffage.
} 
animate or inform a scene, these figures are not necessary to it, and can be removed without disrupting its coherence. While this may be true in terms of composition, their absence would have an impact on its meaning. Because their stature is proportionally small, staffage is more often conceived of as ornamentation; in short, these figures appear as mere objects that add interest but no substance. But staffage can play an active role in how a scene is read, despite their size, and thus their removal would be a detriment. To use Henderson's photograph again as an example, if we remove the three figures, we would be left with essentially the same scene: the ice cone, the falls, and the surrounding rocks and trees covered with frost. The composition would remain whole and complete-yet can the same be said for the photograph's meaning and intent? Without staffage, the significance of the landscape might be lost for the viewer, the ice cone perhaps becoming an almost freakish, even artificial formation. Without some point of reference, although the viewer might be able to make sense of the scene, the photographer's ability to convey the exceptional dimensions of the ice cone would be hampered. Staffage gives this scene a human element to which viewers can relate and thus fully discern this phenomenon. While removing staffage from Ice Cone would not detract from its legibility as a landscape, it would affect a viewer's comprehension of it.

Whereas settings varied from the mundane to the exotic, the most prevalent activity with which these figures occupy themselves was the act of viewing. While viewing may seem like a simple and inherently passive act, this simple act becomes complicated because these figures themselves are being viewed by the individual looking at the photograph. The manner in which these small figures were posed by the photographer- 
themselves another layer in the viewing process, determining precisely what the field of view would hold-tempered how spectators interpreted staffage's role in the scene. Figures facing the camera could have been thought of as presenting or introducing the landscape to the viewer. More often though, these figures stood with their backs to the camera, and as such seemed to take in the same scene with the viewer.

Facing the spectator or not, staffage figures seem to act as intermediaries; they link the viewer to the distant photographed landscape, making it therefore more immediate. In this respect, there seems to be a vicarious element to their function, as if the viewer in the photograph (and indeed the photographer) stands in for the viewer of the photograph. Questions regarding the identity of the posed figure, the photographer, and the viewer become critical considerations for interpreting landscapes. Given the social and cultural currents influencing photographer and spectator, it would seem likely that white middle class men were used and interpreted differently than women and native figures, each imbuing the land with different meanings. In exploration photographs, for example, native figures could represent the absence of European civilization in a given region, and therefore become signs for the need to bring spiritual and moral guidance to that part of the world. White, European figures in foreign territories could act as a prefiguration of the advance of settlement and "civilization." Women of non-native descent were not present in expedition photographs; only after the land had been "tamed" do women appear, illustrating the advance of European civilization and imminent suitability for settlement. 
While staffage may promote this illusion of proximity, another more important aspect also emerges. Having people placed in front of the lens also served to humanize the scene. Establishing a human presence within a landscape aided in making it more familiar. Staffage, however, was not the only means of implying habitation. Glimpses of houses, canoes, telegraph wires, and roads, were but a few elements which insinuated a human presence in otherwise "empty" landscapes. William Hanson Boorne's Lake Louise (fig. 3) made between 1885-89, is an example of this approach. In this photograph, a boat rests on the bank of the lake with tree-covered mountains rising in the background. It is elegant rather than a crude in its construction. Whereas the boat is not in use, its presence implies that this area does serve a function for people, for travel, recreation, or exercise, and thus could be perceived as being under some degree of human control. This is not an untamed wilderness; it has been "civilized."

Perhaps of even greater significance is the realization that the appearance of staffage could not be accidental. In contrast to painting where an artist could brush in figures at his or her discretion, photography, for several decades after its inception, did not allow for this possibility. Exposure time for a plate varied from a few seconds to thirty minutes. If figures were to appear clear, they had to remain still during this time-they had to be aware that they were being photographed. Staffage figures were not accidental elements, but rather deliberate additions to the landscape that required planning and forethought.

\section{Positivism and Photography}

Staffage's reception as a visual or documentary tool in photographs was largely derived 
from how photographic images themselves were comprehended by contemporary viewers. The photograph was, for example, understood by most nineteenth-century viewers as an indexical representation; that is, it was understood as a seemingly unmediated depiction of the "real." Because the resulting image depended on the physical presence of the object being photographed, for figures to appear in a scene, they had to be present during the time of exposure. To quote Roland Barthes: "In every photograph there is the stupefying evidence of this-is-what-happened and how." Further, given their indexical nature, photographs were understood during the nineteenth century to be faithful reproductions of whatever had been positioned before the lens. Being the product of chemical and mechanical processes, photography was believed to be transparent in both content and meaning, and thus free from the human, subjective, and discriminatory influences found in painting and sketching. Photographs were thought to show the world as it was instead of how an artist willed it to be. Cuthbert Bede, a nineteenth-century photographer and commentator, for example, wrote that early photography was superior to painted images, for paintings have "the artist's conventional face, his conventional attitude, his conventional background." ${ }^{\prime 2}$ Photography was believed to be "bias-free."

It has been argued that the development of photography coincided with a need for an objective means of documentation. The nineteenth century for western nations, particularly for Britain, was influenced by a "Positivist" philosophy. Emerging, in part,

\footnotetext{
${ }^{5}$ As quoted in Victor Burgin's essay "Photographic Practice and Art Theory" in Thinking Photography, Victor Burgin, ed. (Houdmills, 1982), 61.
} 
out of the writings of Auguste Comte, Positivism advocated a scientific method that stressed logical deduction and empirical research that, in turn, was to be applied to all aspects of the study of nature and society. It was also a time of extensive technological and social change, typified by a faith in the forces of industrialization, urbanization, and scientific progress. ${ }^{7}$ Victorians firmly believed that the whole of the world's contents could be measured, tabulated, and categorized; therefore, they could conceptually restructure the globe into neat, ultimately controllable chunks of data. Objective study of the world demanded an equally objective technique of documenting it. Photography seemed to provide the means by which external reality could be recorded and catalogued with "absolute material accuracy." ${ }^{18}$ Consider the language used to denote the creation of a photographic image. Photographs were perceived of as being taken as opposed to being made because the "marks of their construction are not immediately visible." 9

Being a product of this rationalist age, photography was implicitly subjected to its ideological constructions, and became an active participant in imperialist agendas. According to Anandi Ramanusthy, "[d]uring the nineteenth-century, the camera joined the gun in the process of colonization. The camera was used to record and define those who were colonized according to the interests of the West." ${ }^{\text {10 }}$ Photography's perceived

\footnotetext{
${ }^{6}$ Cuthbert Bede, Photographic Pleasures (London, 1855), 45.

${ }^{7}$ Derrick Price and Liz Wells, "Thinking About Photography: Debates, Historically and Now,"

Photography: A Critical Introduction, Liz Wells, ed. (London, 1997), 31.

${ }^{8}$ Charles Baudelaire, "The Salon of 1859," Baudelaire, Selected Writings on Art and Artists, P.E. Charvet, ed. (Harmondsworth, 1972), 297.

${ }^{9}$ Derrick Price, "Surveyors and Surveyed: Photography Out and About," Photography: A Critical Introduction, Liz Wells, ed. (London, 1997), 95.

${ }^{10}$ Anandi Ramanusthy, "Constructions of Illusion: Photography and Commodity Culture," Photography: A Critical Introduction, Liz Wells, ed. (London, 1997), 171.
} 
inherent objectivity stimulated its use on government sanctioned civil and military exploration and mapping expeditions as it was believed that the camera's "eye" was more objective than the topographic artists' hand. Staffaged landscapes then, not only delineated what these locales contained, they also aided in defining who colonizers were: photography reinforced the colonial project.

Further, photographing an object (or landscape, in this case) can be seen as the appropriation it, and this, in some way, gives the viewer power over it. To quote John Urry: "It is a power/knowledge relationship. To have visual knowledge of an object is in part to have power, even if momentarily over it." ${ }^{\prime 11}$ Photography's indexical nature serves to collapse the distance between image and referent to such a degree that photographs act more like windows than two-dimensional images circumscribed by time and space. In other words, in the nineteenth century, it was believed that the photograph not only documented its referent, it could also substitute for direct, physical contact with it. This sense of immediacy connoted that possession of the photograph implied possession of the object it depicted. Moreover, photography's apparent "absolute material accuracy" further aided this sense of appropriation as it was a way that allowed the viewer to discipline and naturalize what might otherwise seem strange and frightening. ${ }^{12}$ The unfamiliar becomes familiar because a photograph seemed to reproduce a scene or object the way viewers would have seen it had they actually been there.

\footnotetext{
${ }^{11}$ John Urry, The Tourist Gaze: Leisure and Travel in Contemporary Societies (London, 1990), 139.

${ }^{12}$ Price, 61.
} 


\section{Defining "Landscape"}

Up to this point, the statement that staffage is located in landscapes has been used without qualification; however, it is important to note that the term "landscape" is a complex and inherently problematic term that, too often, is taken for granted. While landscape is generally seen as a "slice of nature," landscape and nature are two distinct entities. Nature, as illustrated by an examination of its etymological roots-from the Latin natura, which itself comes from nasci, meaning to be born-refers to dynamic living processes. As such, it is not a single thing that can be pointed to and clearly delineated. ${ }^{13}$ "Landschap," by contrast, came to the English language from the Dutch at the end of the sixteenth century. Under this rubric, land was not a phenomenon of nature; it was created through the impact of humanity of surrounding environs, which was hardly surprising given the flood fields in the Netherlands were formidable displays of human intervention. ${ }^{14}$ According to Simon Schama in Landscape and Memory, landscape "signified a unit of human occupation, a jurisdiction, as much as that might be a pleasing object of depiction." ${ }^{15}$ The concept of landscape is inescapably connected to a human presence in a scene, either physically demonstrated through the insertion of figures in a scene, or merely implied by showing evidence of humanity's impact-and ultimate ownership. Thus, while landscape has always been associated with defined spaces, containing boundaries that are not always physical, these boundaries are defined

\footnotetext{
${ }^{13}$ Gina Crandell, Nature Pictorialized (Baltimore, 1993), 2.

${ }^{14}$ Simon Schama, Landscape and Memory (Toronto, 1985), 10.

${ }^{15}$ Ibid.
} 
by and in relation to people in a very legal sense. ${ }^{16}$ Landscape is a conceptual construction with meanings imposed on it rather than an actual place. To quote D.W. Meining from his work The Interpretation of Ordinary Landscapes: "...landscape is composed not only of what lies before our eyes but also what lies within our heads."17

Therefore, staffage and landscape have the potential to work in tandem. Staffage, as already discussed, was used as a tool that aided in the explication of a landscape view. It could put a scene into perspective and make it comprehensible, or it could act as an intermediary for the viewer, or staffage could further a sense of control over the expanse depicted. However, the landscape onto which staffage has been projected is not a neutral document of a location's physical forms, but instead, according to Deborah Bright, a "record of human values and actions." ${ }^{18}$ What are the implications of a device that can affect the meaning of a landscape, a scene which in turn is a conceptually constructed view of nature? I would argue that staffage was used in the creation of meaning about the land instead of merely being used a passive documentary tool.

To demonstrate, I turn my attention to a canvas by Richard Wilson entitled Extensive Landscape with Lake and Cottages (fig. 4) of 1744-45. Wilson was a popular eighteenthcentury landscape painter whose careful use of staffage belies their decorative appearance. In the middle ground of this work, a standing male figure and three reclining women relax in a pastoral landscape. Dress, postures, and indeed, the very commission of

\footnotetext{
${ }^{16}$ Crandell, 5 .

${ }^{17}$ D.W. Meining, The Interpretation of Ordinary Landscapes (Oxford, 1979), 34.

${ }^{18}$ Deborah Bright, "Of Mother Nature and Marlboro Men: An Inquiry into the Cultural Meanings of Landscape Photography," The Contest of Meaning (Cambridge, 1989), 126.
} 
this work, identify them as members of the landed gentry. Around them peasants go about their labours with apparent ease and contentment. The social order has been presented through a series of contrasts. ${ }^{19}$ The standing gentleman, visually linked to his playful companions, is turned away from them, as if in the process of surveying his property. His-and the women's-placement in the light contrasts to that of the peasants, who are situated in the dark lower left corner of the canvas, indicating their lower socio-economic status. ${ }^{20}$ It was tacitly believed at this time that the labouring class was the source of Britain's wealth, but their position as "workers" ultimately circumscribed their placement in the social order, and the ruling minority needed to believe that the poor were content with their situation. ${ }^{21}$

David H. Solkin, in his exhibition catalogue, Richard Wilson: Landscape of Reaction, cites this painting as one of many instances where a tranquil, ordered facade masks a reality that was far from calm. Gentry and peasantry are seen here to exist in perfect harmony, apparently content in their social positions, when in truth, strife, crime, and popular disturbances such as food riots easily dispelled such utopian notions. ${ }^{22}$ Wilson, however, has negated these realities, instead displaying the social order as if it were an "unimpeachable ideal." ${ }^{, 23}$ He seeks to justify this divided world of master and servant as both moral and beneficial for everyone, rich and poor alike. The church steeple on the

\footnotetext{
${ }^{19}$ David H. Solkin, Richard Wilson: Landscape of Reaction (London, 1982), 26.

${ }^{20}$ Ibid., 25.

${ }^{21}$ Ibid.

${ }^{22}$ See Anne Bermingham's Landscape and Ideology: The English Rustic Tradition, 1740-1860 (Berkeley, 1986).

${ }^{23}$ Solkin, 25.
} 
horizon served to sanctify the social hierarchy as part of a divine plan. ${ }^{24}$ Thus, through the placement of staffage within the picture plane, issues of land ownership and power relations resonated with sociopolitical principles for contemporary audiences, particularly the landed gentry.

\section{A Question Posed}

Whereas the above example illustrates the social significance of figures in the painted landscape, photographic staffage poses distinctive problems for scholarship and remains a rarely addressed topic. For all its decorative connotations, staffage in painting was seen as being more deliberate because the artist clearly constructs what appears on the canvas. Staffage in photography was often perceived by contemporary viewers to be more of an "accident" of situation than intentional. If a figure appears in a scene, it is often regarded as the product of happenstance; he or she just happened to be there at the time of a plate's exposure. In actuality, the technical intricacy and time-intensive nature of nineteenth-century photography made the inclusion of staffage as premeditated as those in painting. If a photograph was going to contain figures, the photographer had to know in advance, thereby implying that staffage was being used with some purpose in mind.

The use of staffage in nineteenth-century Canadian photographs begs the question why was it seen as necessary at the time for certain landscapes to contain human figures? Henry Peach Robinson's popular and widely-read 1859 book, The Pictorial Effect in Photography, hints at a figure's effect. Although he was more concerned with

\footnotetext{
${ }^{24}$ Ibid., 26.
} 
photographic aesthetic, Robinson deserves note here due to the extent to which his theories were known. Essentially, he claimed that if a figure were to be inserted into a landscape, this had to be done carefully. Whether to vitalize a scene, balance a composition, or impress a point, figures in landscapes had to be used with a specific purpose in mind. ${ }^{25}$ Implied in Robinson's cautioning is the realization that figures could influence how a photograph was read. Thus, if the inclusion of staffage was indeed deliberate, how does the presence of humans affect the reading of landscapes? To return to the examples cited earlier, how does a man fishing in a landscape change how that scene was viewed? What impact did the woman have upon conceptions of Egypt? What did the juxtaposition of native figures and a train imply to contemporary audiences?

Technical limitations of photography during this period demanded that figures were situated in front of the lens consciously with the seemingly explicit intention of establishing a human presence, and the large number of inhabited landscapes photographed demonstrate that this was an accepted convention. Staffage can be used to create meaning, affecting how the photograph was read; it was not merely a documentary device. But why do this? During this period of territorial expansion, fostered by European and Euro-Canadian imperialist policies and attitudes, photography played a key role in recording and categorizing colonized areas. In the case of exploration photographs, staffage established a human presence in what were perceived to be uninhabited, uncivilized tracts of land; consequently, establishing a presence in these areas verifies occupation and possibly even serves as proof of ownership. This is particularly evident in

\footnotetext{
${ }^{25}$ Henry Peach Robinson, The Pictorial Effect in Photography (London, 1869), 52.
} 
expedition photographs from surveys of Canada's Northwest. Considered only suitable for habitation by native peoples and fur company employees, the appearance of white, European figures in this region seems to imply that not only had previous conceptions been revised, Europeans and Euro-Canadians were now actively trying to insert themselves into the Northwest.

Thus, this thesis will elucidate the connection between expansionist concepts of exploration and the use of staffage in expedition photographs taken between 1858 and 1890 through an examination of prevailing attitudes towards possession of land, settlement of the Canadian West, and imperialism. Issues regarding the practice of "mapping" in exploration, attitudes regarding the ideological construction of nature and landscape, the role of photography in documenting exploration, and the technical nature of photography will all be considered. My study will explore these questions through the lens of the social history of photography - that is, examining images for their broader social and cultural implications.

Admittedly, this is quite a heavy burden to put on these small figures, but their frequent appearance in landscapes coupled with an almost total lack of critical analysis suggests that something has been overlooked. Staffage in nineteenth-century Canadian photographs seems to reflect an attitude more than a specific representational problem, perhaps because of contemporary ideology. Drawing on Allan Sekula's discussion of narratives and metanarratives, ${ }^{26}$ I posit that the narrative - the apparent result-was the

\footnotetext{
${ }^{26}$ See Allan Sekula, "On the Invention of Photographic Meaning," Thinking Photography, Victor Burgin, ed. (Houdmills, 1982).
} 
use of staffage in a documentary capacity; while the metanarrative-the overarching, culturally determined cause-marked an assumption by Western powers that seemingly "unsettled" or "uncivilized" areas are somehow already possessed by them, and are simply waiting to be utilized. Staffage becomes, to a degree, an acknowledgment of this assumption of possession, and visually reinforces the idea that this land is indeed possessed by colonizers.

\section{Landscape and Staffage: A Discussion of the Literature}

An acknowledgment of staffage's broader social implications on nineteenth-century Canadian photography is almost entirely absent from the literature. In fact, there does not exist a significant body of research on staffage generally in photography. Considerations of staffage seem to have been relegated to snippets and asides, and has not been the concerted focus of any discussion. Christine Boyanoski's exhibition catalogue Staffage to Centre Stage certainly clarifies staffage's role within visual works, but it is far from a comprehensive examination of this device. The catalogue focuses on works in the collection of the Art Gallery of Ontario which contain staffage, but does not delve into the significance of their presence.

Andrew J. Birrell is one of the most prolific writers about expedition photography in the Canadian Northwest. His works expand a great deal on the social and historical context of survey photography in this region, but does not generally delve into the significance of staffage in fieldwork. For example, in his exhibition catalogue, Into the Silent Land, great care is taken to inform the reader who appears in each survey 
photograph, but the significance of why they were included is not handled. However, in an article about the three North American Boundary Commissions during the 1870s, he does briefly discuss the ideological effect which a white figure has on the photograph Dead Crow Indians Found on Boundary Line by the Corps of Royal Engineers in 1874. Birrell writes that this figure, sitting amongst the decaying corpses, symbolized "the rapacious and violent seizure of the West by whites from the Indians." ${ }^{27}$ While certainly a valid argument, this figure does not strictly qualify as staffage. The manner in which this individual has been employed was to provide scale, but he and the surrounding corpses are in actuality the subject matter of this photograph. Regardless, this is the only work in which Birrell discusses the impact that figures could have on a photograph's meaning. For example, the implications of photographing the "Sappers" posing on a boundary mound in another photograph included in the article are not considered.

This "omission" is also apparent in Birrell's other writings. In his articles about the use of photography on surveys of British Columbia, and the trials of expedition photographer Charles Horetzky, as well in his book focused entirely on the work of Benjamin Baltzly on the 1871 Geological Survey of Canada, the possible ideological influences of staffage on photographic meaning are not considered. ${ }^{28}$ The chapter dealing specifically with photography in the West, North, and British Columbia in Birrell and Ralph Greenhill's

\footnotetext{
${ }^{27}$ Andrew J. Birrell, "The North American Boundary Commission: Three Photographic Expeditions, 1872-74," History of Photography 20.2 (Summer 1996): 120.

${ }^{28}$ See Andrew Birrell's "Fortunes of a Misfit: Charles Horetzky," Alberta Historical Review (Winter 1971); "Survey Photography in British Columbia, 1858-1900," BC Studies (Winter 1981-82); Benjamin Baltzly: Photographs and Journal of an Expedition Through British Columbia, 1871 (Toronto, 1978).
} 
Canadian Photography, 1839-1920, ${ }^{29}$ also does not discuss staffage. The thrust of this excellent book is to provide an overall survey of photographers and photographic practice in Canada, and thus is limited to generalities with respect to individual images.

Another important work is Richard Huyda's Camera in the Interior: $1858,^{30}$ which deals specifically with the efforts of Humphrey Lloyd Hime on the Assiniboine and Saskatchewan Exploring Expedition of 1858. This survey is of particular importance as it was the first expedition in Canada to employ a photographer. However, whereas Huyda has provided and superb detailing of the historical facts surrounding this expedition and photographic procedures of the day, the larger significance of staffage-and indeed photography—was not addressed.

The general literature on landscape photography, too, has neglected staffage figures. Here, two distinct trends emerge: absence and neutrality. Often, the absence of people in landscape photographs are thought of being "pure" landscapes, as showcases for the glory of God's creation, defining this deity's presence on earth. ${ }^{31}$ Hence, it would seem logical to ask if the presence of people implied the absence of God. Simply inverting this relationship, though, is too simple a solution-the presence of people does not necessarily denote the absence of God. In many cases, God's presence was emphasized by the situation of small figures in panoramic landscapes. The figures' smallness in relation to the evidence of God's greatness could serve to accentuate God's power, defining humans as supplicants to God, as seen, for example, in Thomas Moran's canvas The

\footnotetext{
${ }^{29}$ See Greenhill and Birrell's Canadian Photography, 1839-1920 (Toronto, 1979).

${ }^{30}$ See Richard J. Huyda's Camera in the Interior: 1858 (Toronto, 1975).
} 
Grand Canyon of the Yellowstone of 1872 (fig. 5). Further, this inversion is also hindered by an inherent contradiction in its basic presupposition. "Pure" landscapes are pure fictions. The act of taking a photograph necessarily establishes the presence of at least one person: the photographer. This individual is not an objective or passive recorder, and has a personal, internal governing ideology which has an impact on a photograph's appearance. Composing, cropping, and exposing the plate effectively demonstrates a human presence in the photograph: the landscape is never truly empty. As Heinrich Schwarz has stated, the photograph is "...bound to point not only at the apparatus, but also at the person handling it and imposing his will upon it."132

In the other discernible trend in the literature, when figures do appear in compositions, their presence is not analyzed. Again, Andrew J. Birrell, in his important study Into the Silent Land, one of the few exhibitions catalogues and historical examinations of Canadian exploration photographs, lays out the goals of each survey, carefully delineating between photographic and expedition segments and explaining how the former was to support the latter. However, his groundbreaking study is more concerned with a broad historical picture than with the specific (and coded) implications of these figures.

This thesis addresses those gaps in the scholarship of historical Canadian photography. By examining the coded meanings of staffage figures, I hope to expand the discussion in this field of study. The images I have selected to examine in this thesis have

\footnotetext{
${ }^{31}$ Estelle Jussim and Elizabeth Lindquist-Cock, Landscape as Photograph (New Haven, 1985), 24.

${ }^{32}$ Schwarz, Heinrich, Art and Photography (Kayton, 1985), 82.
} 
been drawn primarily, but not exclusively, from the works of official photographers on exploratory expeditions into Canada's Northwest between 1858 and 1890. Specifically, I shall be analyzing photographs taken by Humphrey Lloyd Hime from the 1858 Assiniboine and Saskatchewan Exploring Expedition, and by the Corps of Royal Engineers on the North American Boundary Commission, as well as Benjamin Baltzly's work from the 1871 Geological Survey of Canada mission, and lastly, photographs from the 1871 to 1879 Canadian Pacific Railway Surveys by Charles Horetzky. Also included are two non-official photographs taken between 1865 and 1890 by commercial photographers, Charles Gentile and William Hanson Boorne, who although were not attached to any exploration party, produced images that exhibit characteristics similar to government sanctioned works.

\section{Establishing a Path}

Thus, this thesis will examine staffage in nineteenth-century Canadian expeditionary photographs by initially addressing the largest context for this work. This will be accomplished by establishing a historical and cultural context through which the implications of staffage in these types of images will be read. Bringing together recent literature and archival materials, the format for this work will adopt a "funnel"-like form, moving from broad, overarching cultural factors, narrowing to an examination of the internal factors impelling the actions taken towards the Northwest, and, lastly, focusing on the specific questions of how these factors were enacted in the field. In other words, this thesis will travel from the conceptual to the practical and everyday. Readings of 
specific images will be situated within each section of this framework. It is only by contextualizing these works that the possible influences of staffage on photographic meaning can be made apparent.

The first chapter will examine how the dominant ideology of imperialism affected photographic readings of distant places, and how the use of staffage in these images bolstered certain preconceptions about the land. Specifically, staffage-in the form of white, European male figures—established "proof" of ownership of the lands in which they stood, in a legal as well as a metaphorical sense. Given European powers' seemingly insatiable appetite for territory during the nineteenth century and their consequent expansion beyond their own borders, staffage provided a means to verify their possession of newly acquired areas, acting as a kind of visual receipt. This "occupation" also served to confirm the overarching colonial imperative of cultural hegemony, the imperialist quest to re-fashion the world in a European image. Staffage, then, served to provide proof of this project as well. European figures in the landscape established the presence of "civilization," in addition to demonstrating their dominance over indigenous inhabitants.

The second chapter will examine the more practical and specific aspects of Canadian expansionism at mid-century. Despite several centuries of European presence in British North America, the territory's interior largely remained terra incognita to the majority of its dwellers at this time. Thus, the first object of consideration will be the examination of pre-existing conceptions of the Northwest coupled with the transformation these views underwent as the region's potential was re-evaluated under imperialism's acquisitive eye. 
Revealing the unknown, however, necessitated an intense re-examination of the land, leading to one of the most intensive periods of exploration in Canada's history. To this end, the role geography played in this unveiling shall be investigated, paying specific attention to the emerging use of photography as a means of documenting these "newly discovered" areas. In particular, how photography was used as a tool of intellectual conquest by imperialists shall be examined. In this context, it will be shown, that staffage becomes of particular significance in these images as it plays a key role in the conceptual transfiguration of the Northwest, as well as underscoring imperial assumptions towards the land.

The third chapter will more closely address the methods and procedures of nineteenth-century photography, particularly as it pertains to expeditionary work. While it is generally understood that nineteenth-century photography is quite different from the images produced by the "point-and-shoot" cameras we are accustomed to today, the difficulty of this technology needs to be addressed fully. Indeed, the highly complex, labour-intensive nature of nineteenth-century photography made field-work incredibly difficult; the large numbers of images produced under extreme circumstances during this time is a remarkable achievement and a testament to individual doggedness. However, the inclusion of photographers on expeditionary missions had a far more significant implication. The increasing reliance on photographs as documents speaks to their perceived power as an impartial purveyor of facts; the traditional mediums of sketching and painting were no longer seen as entirely adequate techniques for transferring visual information for official purposes. This chapter shall examine the methods and procedures 
of nineteenth-century photography, as well as attempt to explain why these images were given such authority. Accordingly, the concept of the documentary and the manner in which photographs were disseminated to the public will also be discussed. Given the technical complexity of the photographic process, the consequences of having staffage figures in expedition photographs become particularly significant. 


\section{Establishing a Presence in the Land: Imperialism, Canada, and the West}

This chapter will examine how the overarching cultural ideology of imperialism affected photographic readings of distant places, paying specific attention to how the use of staffage in these images supported or even impelled certain preconceptions about the land. As noted in the introduction, staffage-in the form of white, European male figures - established "proof" of ownership of the lands in which they stood, in a legal as well as a metaphorical sense. Given the extension of political and cultural authority into foreign territories by European powers' during the nineteenth century, staffage provided a means to verify their possession of newly acquired areas, acting as a kind of visual receipt. Moreover, this implied "occupation" through the use of staffage figures also acted to confirm the dominant colonial imperative of cultural hegemony, providing proof of this project as well. The insertion of European figures into the landscape established the presence of "civilization" in exotic areas, as well as demonstrating their control over indigenous inhabitants. However, before these ideas can be fully examined, a brief introduction to imperialism and Canada's role within this ideology is needed.

\section{The Age of Innocence: British Imperialism}

Imperialism, for the purposes of this study, refers to an attitude or mind-set which conditioned foreign policy practices in Western European nations, particularly the deep- 
seated acquisitive impulse that dominated roughly between 1780 and $1914 .{ }^{1}$ The present study is not intended to be a comprehensive analysis of imperialism in the nineteenth century, but rather a selective approach investigating one aspect of what was a highly complex phenomenon. At its most basic, the principle focus of imperialism was land: who owned it, who settled and worked it. The nineteenth century witnessed the concentration of power in a few Western nations-Britain, France, and later the United States - that allowed the accumulation of territory and subjects on an extraordinary scale. $^{2}$ The focus here will be specifically on British imperial policy, and particularly how it took form in North America.

However, the acquisition of territory involved more than merely defining where a nation's borders lay. Although this may seem self-evident, possession of lands was ultimately rooted in questions of power. Skirmishes, battles, wars, and revolutions fought under the auspices of religion, ideology, or succession inevitably came down to questions of sovereignty: who had the right to control which territories. Political authority, the ability to claim taxes, to make laws, and generally to direct the will of its citizenry was fundamentally rooted in the possession of land, both in the direct legal sense as well as in the less concrete patriotic manner. In other words, land provided the base from which power arose. ${ }^{3}$ Therefore, the more land to which one could lay claim, the greater the

\footnotetext{
${ }^{1}$ This view is very much in keeping with recent work by historians and theorists, particularly that of John MacKenzie, who argue that imperialism was not motivated solely by the lures of economic gains and political power, but was equally shaped by a prevalent set of cultural beliefs informed in no small part by a faith in their racial superiority. John M. MacKenzie, Propaganda and Empire: The Manipulation of British Public Opinion, 1880-1960 (Manchester, 1984), 1-14.

${ }^{2}$ Edward Said, Culture and Imperialism (New York, 1993), 7.

${ }^{3}$ Jackson, J.B., "The Vernacular Landscape," Landscape Meaning and Values, Edmund C. Penning-Rowsell,
} 
amount of power one wielded. Viewed in this light, the drive behind nineteenth-century imperialist expansion can be viewed very simply as an extension of this basic premise. The accumulation of lands had undeniable economic benefits, and may have very well been the precipitous cause for expansion, but the associated accumulation of power certainly had its own inducements as well. However, although the pursuit of land will be of primary concern here, there is another critical aspect of imperialism which must be addressed before we can proceed.

Early scholarship devoted to British imperialism has tended to focus on the economic imperatives of imperialism, on the dynamic and almost self-propelling relationship between the forces of industrialization and the need for raw materials and markets. Until the 1950s, historians, such as Hugh E. Egerton in his A Short History of British Colonial Policy, 1606-1909, ${ }^{4}$ generally justified Britain's expansionist policies as a result from Continental pressures and feelings of commercial and political insecurity after a thirty year period of supposed "anti-imperialism" where colonies were seen, by some politicians, as a burden rather than a benefit to the Empire. It was only around 1870, according to this interpretation, that due to the increased industrialization of Continental competitors, a lack of raw materials, and a need for new markets, that Britain was forced to join the "notorious scramble for colonies." This idea was challenged in scholarship of the 1970s, but economics was still posited as the centralizing factor of new

et al., eds. (London, 1986), 71-74.

${ }^{4}$ Hugh E. Egerton, A Short History of British Colonial Policy, 1606-1909 (London, 12th ed. 1950). Although this work was originally published in 1897, the pervasiveness of his point of view was demonstrated by its continued re-publication.

${ }^{5}$ C.C. Eldridge, Victorian Imperialism (London, 1978), 6. 
interpretations. Rather than a period of "anti-imperialism," historians characterized nineteenth-century foreign policies as a time of continuous economic expansion that did not necessarily include or require political domination. John Gallagher and Ronald Robinson, in their famous article "The Imperialism of Free Trade," portray this era as an "informal empire," where trade, not territory, was Britain's primary objective. Political domination over a territory transpired only when "necessary." Naturally, when British interests became threatened by either internal or external factors, "necessity" quickly became reality.

However, these explanations emphasized economic factors, making them the principle impetus of imperialist practices. Requirement for raw materials, markets, and trade routes did provide powerful incentives for extending borders and acquiring new land, but these were perhaps the consequences of larger, more complex conceptual constructions instead of the direct causes. Recent scholarship, such as John MacKenzie's Propaganda and Empire, has challenged earlier monolithic economic conceptions, alternately asserting ideological structures where moral imperatives-humanitarian and missionary goals of converting "heathens" to Christianity and civilizing "wilderness", and an inherent belief in a superiority of Western race and culture-provided the drive for expansion. Domination of distant lands and foreign peoples was the result of these ideologies. Or, in other words, morality was invoked to rationalize, even mask, economic gains. As Edward Said has argued:

6 John Gallagher and Ronald Robinson, "The Imperialism of Free Trade." Economic History Review 2nd ser. 6 (1953): 1-15. 
Neither imperialism nor colonialism is a simple act of accumulation and acquisition. Both are supported and perhaps impelled by impressive ideological formations that include the notion that certain territories require and beseech domination...?

Economic factors still played a large role in the acquisition of land, and may have even been the primary rationale for expansion, but the rhetoric used to justify land gains puts forth a higher ideal. This is not to imply that imperialists consciously deceived themselves and others. The moral centre that guided their beliefs and actions was held to be both right and just. Canadian politician John Charlton, reflecting upon the meaning of imperialism in 1900, made this position abundantly clear.

The meaning to the world of this growth of the Imperialistic spirit is not one of menace. It proffers a benediction of good will and of hope for the future. Great Britain's course in the past had been one calculated to promote the best interests of humanity. Such will be her course in the future; and vast, unreclaimed regions of the earth, such as the dark, unappropriated portions of Africa, will yet fall under her sway. The faster this destiny is fulfilled, the better for the inhabitants, and for the interests of humanity generally. Her colonial rule is a just and beneficent one. She holds the scales of justice with an even hand, and sedulously seeks to promote the interests of the people who come under her sway, and to develop the resources and increase the wealth of the lands over which her flag floats. ${ }^{8}$

Because Western European nations often posited themselves as physically, mentally, and morally superior to other races, they took it upon themselves, as the "white man's burden" " or obligation, to spread Western civilization, technology, and Christian gospel. It has been asserted that the core of this belief was rooted in a desire for cultural hegemony-the urge to reproduce Western European ideological constructions

\footnotetext{
${ }^{7}$ Said, 9.

${ }^{8}$ John Charlton, "Canada and Imperialism," [Unknown Title] (n.p., 1900), 672.
} 
throughout the world, creating a harmonious, productive, global "family" united by a commonality of thought and deed. These colonial children were, of course, expected to play nicely in the sandbox and obey their "parents" wishes.

Indeed, this dream is quite evident in writings from the time. For example, in a lecture to Montreal's Mercantile Library Association in March of 1858, Alexander Morris, who later became the Lieutenant-Governor of Manitoba, the Northwest Territories, and Keewatin, expressed his belief that the magnificent futures of Australia and "British America" lay in their adherence to British cultural structures:

Millions of people acknowledge her sway. ...[D]eriving from Britain their religions, their literature, their language, and their national characteristics...the impress of the British mind is stamped upon and reproduced, in what are in the lapse of time destined eventually to be great kindred nations bound together by the ties of origin and by parental and filial affection. ${ }^{10}$

However, the Earl of Carnarvon, a minister in Disraeli's cabinet, perhaps best expressed the true strength and meaning of imperialism—as it was conceived at the time-in the following 1878 statement:

[In British colonies] we have races struggling to emerge into civilization to whom emancipation from servitude is but the foretaste of the far higher law of liberty and progress to which they might attain; as vast populations like those in India sitting like children in the shadow of doubt and poverty and sorrow, yet looking up to us for guidance and help. To them, it is our part to give wise laws, good government, and a well ordered finance, which is the foundation of good things in human communities; it is ours to supply them with a system... where the light of religion and morality can penetrate into the darkest dwelling places. [my italics] ${ }^{11}$

\footnotetext{
${ }^{9}$ Eldridge, 2.

${ }^{10}$ Alexander Morris, Nova Britannia (Toronto, 1884), 5.

${ }^{11}$ As quoted in Eldridge, 2.
} 
This statement lays bare Said's observations in Culture and Imperialism. Without Western guidance, according to the cultural logic of imperialism, colonies would continue to reside in ignorance, but only in what imperialists conceived to be the defining elements of civilization, which in turn were based upon their own systems of government, religion, and morality. Civilization was determined by how closely colonies reproduced Western institutions and value systems. The paternalistic nature of imperialism is also clearly evident in the Earl of Carnarvon's statement and further emphasizes Said's assertion that colonial acts are impelled by ideological constructions. ${ }^{12}$ Viewing colonies as children, however, also rationalized imperialists' political intrusion as they believed they had the duty, in the name of civilization and liberty, to shed light into the "darkest dwelling places." Conversely though, imperialist attempts to make colonists-particularly colonists of different races-more like Europeans only served to accentuate the divisions between them. Therefore, not only did imperialism reinforce colonizers' beliefs and values about themselves, it also functioned to distance them further from the very peoples they were attempting to aid. This allowed them to justify their righteous cause while simultaneously maintaining a dominant/subordinate power relationship with their colonies. ${ }^{13}$

Despite selfless claims of spreading light, liberty, and civilization, the nineteenth century stands as a remarkable period of exploitation and of violence that accompanied the expansion of European nations. In 1800, European powers claimed dominance over

\footnotetext{
${ }^{12}$ Said, 9.

${ }^{13}$ See Homi K. Bhabha's The Location of Culture (London, 1994).
} 
$55 \%$ of the earth's surface but occupied only $35 \%$, although they may not have been fully cognizant of how large the areas they claimed ownership over were. By 1878 , they held $67 \%$, acquiring, on average, about 83,000 square miles per year; by 1914 they held $87 \%$, gaining approximately 240,000 square miles a year, including all colonies, dominions, protectorates, dependencies, and commonwealths. ${ }^{14}$ Such an astonishing accumulation of land "pegged out...for posterity" ${ }^{15}$ was not seen as a particularly extraordinary occurrence by many contemporary British writers and scholars. Indeed, coupled with colonial rhetoric, expansion was viewed as a natural, if not inevitable, result of British character. This attitude is evidenced by Reverend William Parr Griswell, a scholar at Oxford's Brasenose College, who claimed that the "colonizing virtues have asserted themselves in spite of difficulties" and like "the hardy plant [it] has grown and thriven, thrusting to its own vitality...."16 The acquisition of territories was constructed therefore as unconscious and uncontrived, but ultimately to everyone's benefit. Nonetheless, although moral imperatives may have been used to justify expansionist policies, it is quite apparent that the acquisition of land—with its attendant economic power-was also very much a part of imperialist ideals. Given these aspects of imperialism, how did Canada participate in this mass trend of acquisition and acculturalization?

\footnotetext{
${ }^{14}$ Said, 8.

${ }^{15}$ William Parr Griswell, The Growth and Administration of British Colonies, 1837-1897 (London, 1898), 12.

${ }^{16}$ Ibid.
} 


\section{The Ties That Bind: Canada and Imperialism}

Imperialist ideology may not seem immediately applicable to Canada's historical situation. Usually, imperialism is applied to Canada in terms of its relationship to Britain, first as a colony then as a dominion. This characterization, while in itself valid, essentially pushes Canada to the sidelines-relegating the country to adjunct rather than contributor-in effect isolating Canada from contemporary ideological currents. But it was far from immune to this cultural force. Canada was subjected to the "imperialist project" as a colony, yet it also acted as aggressor. Rather than depart its own shores and traverse across trackless seas to gather territory, resources, profit, and prestige-which would have been an impossible feat given a lack of military organization, for oneimperialists in Canada turned inwards, charting and exploring the continent's western interior. The acquisition of the Hudson Bay Company lands in 1858, and the addition of provinces during Confederation added well over 2,700,000 million of acres of land to the 800,000 already held under Canada's jurisdiction. Although these acquisitions may initially seem to be bloodless political and economic transactions, with Britain merely conceding control of these lands to its fledgling dominion, the apparent result reflected those of any colonized area. Native peoples were displaced to make way for settlers who were encouraged ostensibly because they could make better use of the land; an infrastructure - the building of the transcontinental railway from 1880-1885, and the formation of the Northwest Mounted Police in 1872, for example-was established as a means to facilitate control over the land and its inhabitants in order to insure that these 
areas would be productive, contributing constituents to the benefit of the whole country. In short, it marked a typical imperialist procedure.

However, as imperialism in Canada was conducted within the country's boundaries, it had a distinctly nationalistic tone that may initially seem contradictory. While Canada did amass a great deal of land, contributing to its economic power and international clout, these actions were undertaken more as a means to strengthen itself as a nation and to facilitate cohesion between disparate provinces. Not only did Canada seek to bolster unity by making itself indispensable to England, the very country from which it had been born, many imperialists also held that the only way for Canada to survive as a distinct political body was through continued affiliation with Britain. Breaking away from the Empire was analogous to "republican" values associated with the United States, and was found to be an unpalatable alternative:

We believe that union is better than disunion, that loyalty is a better guarantee for true growth than restlessness or rebellion, that building up is better than pulling down. The ties that bind us to the Fatherland must be multiplied, the connection made closer and politically complete. Her traditions, her forms, her moral elevation, her historic grandeur shall be ours forever. And if we share her glory, we shall not shrink even at the outset from sharing her responsibilities. ${ }^{17}$

Imperialists in Canada believed they could attain national status only by maintaining the country's connections to the Empire through military and economic cooperation, as well as constitutional policies. Naturally, this was not a unilateral belief: nationalists held those acts to be incompatible with issues of internal unity and self-government. ${ }^{18}$

\footnotetext{
${ }^{17}$ George M. Grant, Ocean to Ocean (Rutland, Rev. ed. 1873), 301.

${ }^{18}$ Carl Berger, The Sense of Power (Toronto, 1970), 3.
} 
Nevertheless, the imperial view conditioned a number of institutional policies, particularly those regarding expansion, settlement, and infrastructure. They maintained that collaboration was the means to function on par with Britain, to be regarded as a partner, if not an equal, instead of a dependent subsidiary. However, there remained much to do if Canada was to be able to play this role. Sir John A. Macdonald, after Confederation in 1867 , initiated a number of policies, including a protective tariff, construction of a transcontinental railway, and settlement of the West, designed to give internal structuring that would, it was hoped, strengthen what Carl Berger, in his work The Sense of Power, termed the "flimsy political entity"19 that was Canada. Ostensibly, these acts were undertaken to make Canada a viable auxiliary "kingdom" to the Empire. Establishment of branches of the Imperial Federation League in Canada in 1884 further represented an organized effort to reinforce the imperial tie.

Many imperialists founded Canada's expanding role in the Empire on natural resources, believing that material support would make the country the "keystone" of the British imperial system. Canada could provide harbours for traveling ships; the proposed Canadian Pacific Railway could enhance communication between Britain, Australia, and India; and resources could be easily transported from the interior to the motherland through rivers leading to the Atlantic Ocean. ${ }^{20}$ Most importantly, Canada was seen as being able to provide exports of coal, wheat, lumber, and minerals to Britain itself. This belief was not only held by Canadians; British subjects also saw the possibilities of

\footnotetext{
${ }^{19}$ Ibid., 4.

${ }^{20}$ Ibid., 10.
} 
material support from their colonies-this being a key element of support for their expansionist policies. For example, at the 1871 Conference on Colonial Questions, Blanchard Jerrold, writer and journalist, presented a paper detailing how colonies could act as food stores for Great Britain: "If our present, fast steamers were multiplied, and facilities of transit further increased, they could bring food supplies for England of great value, more than sufficient to feed all England."21 Import/export statistics for 1883 confirm that this what occurred. At that time, half of the total amount of produce exported from Canada went to Britain-who in turn had supplied two-fifths of Canada's imports. ${ }^{22}$ Moreover, it was felt that this interdependence was a right and just course of action. Lord Durham, in his 1839 Report on the Affairs of British North America, had made this view abundantly clear:

The country which has founded and maintained these Colonies at a vast expense of blood and treasure, may justly expect its compensation in turning their unappropriated resources to the account of its own redundant population; they are the rightful patrimony of the English people, the ample appendage which God and Nature have set aside in the New World for those whose lot has assigned them but insufficient portions in the Old. ... [A] connextion secured by the link of kindred origin and mutual benefits may continue to bind to the British Empire the ample territories of its North American Provinces.... ${ }^{23}$

Specifically, Canada's West was seen as the means to fulfill this goal of imperial partnership. Viewed for centuries as a barren, uncivilized wasteland, the "Northwest," underwent a conceptual revision around mid-century-a transformation that will be

${ }^{21}$ Blanchard Jerrold, "The Colonies as Food Stores for Great Britain," Discussion of Colonial Questions (London, 1872), 180.

${ }^{22}$ Trevor H. Levere, "The British Association Goes West: Montreal 1884," Transactions of the Royal Society of Canada 20 (1982), 496.

${ }^{23}$ John George Lambton, Earl of Durham, Report on the Affairs of British North America (London, 1839), 
discussed in more detail in the next chapter. It was now seen as the repository for the future wealth, prosperity, and power of the fledgling nation, and by extension, the Empire. The sheer size of territory contained in the Northwest inspired many dreams centred around the commercial implications of its development and exploitation through trade, agriculture, forestry, and mining. ${ }^{24}$ As John Charlton proclaimed: "As exploration proceeds, and the character of the soil and climate of the Dominion, and the extent of its resources, are better known, the estimate of its importance rises."25

Canada's power as a nation then, was seen to lie in its natural resources, and the exploitation of these was a means of enhancing its status. However, at mid-century, there was a general ignorance about what the character of the Northwest truly was. All proclamations extolling the abundance of resources just lying in wait were almost pure speculation; they nonetheless fostered the belief that Western expansion was not only necessary to the protection of national interests, but also fundamental to the role of Canada within the Empire. Doug Owram, in his book Promise of Eden, argues that during the late 1850 s there was a general feeling among Canadians that the country had reached a crucial juncture in its development. As a colony, then country, stretched out along the edges of the North American continent and St. Lawrence seaway, it was believed that Canada was outgrowing it boundaries, and "failure to expand would result in stagnation" and obscurity. ${ }^{26}$ To quote William Kennedy, a long-time advocate for

$12-13$.

${ }^{24}$ Doug Owram, Promise of Eden (Toronto, 2nd ed. 1992), 48.

${ }^{25}$ Charlton, 666.

${ }^{26}$ Owram, 47. 
Western penetration, from a speech delivered to the Toronto Board of Trade in December 1856:

Canadians now saw that the comparatively small fragment of this continent which they occupied would soon be both too narrow and too short for them, too small a field on which to exercise and develop their new born energies. ${ }^{27}$

The Globe perhaps expressed this sentiment more succinctly, and fully in keeping with the dominant acquisitive mode, when on December 10,1856, it boldly proclaimed that Canadians were "looking for new worlds to conquer." ${ }^{28}$ The new world was to be the Northwest. As Alexander Morris espoused in another lecture in 1858:

...the people of British North America must take high views of their plain and manifest responsibilities. They must evince an adequate appreciation of their duties, and must possess a through knowledge of the advantages which they possess, and of the vast resources which Providence has placed at their disposal, in order that they may advance steadily toward that high position among nations which they may yet attain-in order that they may enter upon the full fruition of that rich inheritance of civil and religious liberty, and of high social and political privileges, which is their birthright as an offshoot of the three united nations who compose the British people. ${ }^{29}$

Thus, exploratory expeditions became crucial for Canadian imperialists for it was only through intense documentation of the land that the country's future economic and political strength could be determined. Substantial interior penetration of the Northwest was undertaken around mid-century to ascertain the amount of territory available and, more importantly, the resources that could be wrought from it.

\footnotetext{
${ }^{27}$ William Kennedy in the Globe, 19 December 1856.

${ }^{28}$ Globe, 10 December 1856.

${ }^{29}$ Morris, 58.
} 
Gains in land and all its potential riches were of great concern to officials at the time, and thus deserve attention; however, espoused moral imperatives for settlement should not be overlooked either. As discussed earlier, nineteenth-century imperialism masked material gains achieved through the acquisition of lands and peoples with moral mandates. Canada, as with other imperialist powers, was not immune to this influence. Many of the same "humanitarian" goals of civilizing the supposedly uncivilized and spreading Christianity into the "dark, dwelling places" of the globe conditioned conceptions of European and Euro-Canadian colonization. Reverend Griffith O. Corbett, resident minister and occasional physician in Red River from 1852 to 1867 , writing to the Duke of Buckingham in 1868 advocated that Rupert's Land be designated as a Crown colony rather than be annexed to Canada. While Corbett extolled the virtues of the soil, defined the climate, and detailed where fertile regions were to be found, it was nonetheless moral imperatives which were of primary concern. He rationalized his position by citing the necessity of bringing Christianity to the region. Wilderness, to a missionary, represented a spiritual as well as physical void, and the absence of Christianity in the Northwest made it seem a "heathen and moral desert." Paradise could only be attained through Christianizing the wilderness: "this moral wilderness [would] blossom as a rose, and the region of darkness and desolation become as the garden of the Lord. ${ }^{\prime 30}$ Corbett wrote how he tried to encourage those in England who were:

\footnotetext{
${ }^{30}$ John West, Substance of a Journal During a Residence at Red River (London, 1824), 4.
} 
...blessed with leisure and means, and induce them to contribute their substance, weight, and influence to spread Christianity all over that continent, and to promote Christian colonization and Christian communities under legal and proper Government from end of the land to the other. ${ }^{31}$

Corbett also explained why the Hudson's Bay Company license-a source of concern and anger to many expansionists-obstructed the flow of Christian ideals into the Northwest. Colonization was such a vital undertaking, he believed, to the preservation of Christianity in the Northwest due to the "...continuance of a condition of things bordering on Anarchy." ${ }^{32}$ These statements encapsulate the supposition by Western powers that without their paternalistic control and moral influence, civilization could not develop and these unshriven areas would continue to wallow in "savagery."

Some individuals even visualized interior penetration as providing a corridor for British influence, in effect acting as a channel through which "civilization" could flow. Henry Youle Hind, leader of the first Canadian western exploration party-the Assiniboine and Saskatchewan Exploring Expedition of 1857-1858-took such a view. Hind envisioned what had become known as the "Fertile Belt" to be an "oasis"-or Eden-of rich soil and extensive pasturage stretching from the Lake of the Woods to the Rocky Mountains. ${ }^{33}$ Bounded on the north by the sub-arctic and on the south by what was theorized to be an arid, uninhabitable desert, this band of earth was seen to have a "Providential disposition":

\footnotetext{
${ }^{31}$ Griffith O. Corbett, Notes of Rupert's Land (N.p., 1868), 3-4.

${ }^{32}$ Ibid., vi.

${ }^{33}$ Further surveys of the Fertile Belt extended its supposed boundaries, but its existence was later refuted altogether.
} 
Does not the Fertile Belt best point out the true path across the continent? The way which, first British Columbia, then China, then India may be reached from Europe. The way by which British civilization, laws and liberties are to be carried to the Pacific and thence to Asia, through BRITISH AMERICA. ${ }^{34}$

Here, the land itself was seen to point the way, even to embrace imperialism's directives.

Further, the geographical arrangement of this fertile band which supposedly traversed the interior was seen as being divinely sanctioned, thereby justifying western settlement and beyond as "white man's destiny." Also evident in this statement is the ideal of cultural hegemony so actively sought after by imperialists. The Northwest was proposed to act as a "thoroughfare" through which moral and religious imperatives could flow supposedly unimpeded to Asia.

However, Canada was not only to act as a colonial highway for Britain; it too was subject to nationalist ambitions. There was a sincere desire to "build up a nation on the British plan." ${ }^{35}$ Joseph Howe, Provincial Secretary for Nova Scotia, in a speech delivered at Southampton on January 14, 1851 made this goal very clear. He called for the continued close relationship between the North American provinces and the Mother Country so as " $[\mathrm{t}$ ]o reproduce England on the other side of the Atlantic-to make the children, in institutions, feelings, and civilization, as much like the parent as possible. ${ }^{36}$ Moreover, the Northwest was integral to the development of "British society and

\footnotetext{
${ }^{34}$ National Archives of Canada. Walter Butler Cheadle Papers. MG 24, H 40, Vol.1, Reel C-6824. Henry Youle Hind, Sketch of an Overland Route to British Columbia (1862), v-vi.

${ }^{35}$ Thomas Cross, "Canada and the Empire," Rose-Belford's Canadian Monthly VII (Sept.1881). As quoted in Owram, 126.

${ }^{36}$ Joseph Howe, On the Importance and Values to Great Britain of Her North American Colomies (London, 1857), 6.
} 
morality across the North American continent." ${ }^{37}$ As Doug Owram has argued, because the

...British Empire was thought to represent man's highest achievement in the development of governmental and social institutions...[t]he Northwest, promising great economic wealth, seemed to give Canada a unique opportunity to implant firmly these noble institutions in a rising world power. ${ }^{38}$

The sheer size of territory under speculation seemed to proffer "an unequaled opportunity of developing British institutions on a grand scale." ${ }^{39}$ The unilateral adoption of British ideals would fulfill the aspiration for creating "the Britain of the West."

\section{"We" Stand Here: Asserting Ownership Through Staffage}

The statements noted above expressed some of the motivations and justifications for imperialism, both abroad and within Canada, but it remains to be seen how this project was actually carried out. European nations often complained about the administrative costs associated with establishing colonies as pieces of their greater political entity, yet it is indisputable that they benefited tremendously from these arrangements. Revenues generated from these outposts, the satisfaction experienced from cultivating what was believed to be a Christian, "civilizing" campaign, as well as the undeniable sense of power perceived from having large amounts of territory to command undoubtedly swelled their sense of national pride, amplified their international status, and filled the

\footnotetext{
${ }^{37}$ Owram, 127.

${ }^{38}$ Ibid., 126.

${ }^{39}$ [Charles?] Wilkes, "Britain's Future Corn Supply," Rose-Belford's Canadian Monthly V (Aug. 1880). As quoted in Owram, 126.
} 
treasury. Practically however, this required Western powers to travel great distances to claim-oft times forcibly-unfamiliar and possibly unfriendly territories. To quote Edward Said: "At some very basic level, imperialism means thinking about, settling on, controlling land that you do not possess, that is distant, that is lived on and owned by others." 40

Thus, while laying claim to far-flung territories was one thing, proving and maintaining internationally-recognized possession, was quite a different matter. Politicians, the church, and government officials were certainly aware, to some degree, about their country's activities in foreign lands - even if only through paperwork-but short of actually visiting these lands, there was nothing which offered incontrovertible proof that they were indeed occupied by them. Granted, documenting these places through measurements, reports, charts, and maps provided a means of appropriation through sheer classification that was believed to be authoritative because it seemed both objective and scientifically based. However, for the homebound politician, clerk, or citizen, there was no way to verify the assertions produced through these methods. Visual representations also acted as a means of appropriation, ${ }^{41}$ but the traditional modes of sketching and painting were no longer seen as adequate recording tools. Although artists and draughtmen continued to be included on several expeditions, officials were drawn to photography due to assumptions regarding its apparent unmediated verisimilitude. Variations-or lack-in the artistic skills of individuals coupled with unavoidable

\footnotetext{
${ }^{40}$ Said, 7.

${ }^{41}$ John Urry, The Tourist Gaze (London, 1990), 139.
} 
human biases produced images that could not claim to be either perfectly accurate nor entirely objective- two criteria greatly valued by Victorians. Photographs, commonly seen as the product of a mechanical device by which images were chemically constituted, were believed to impart dispassionate veracity to whatever scene or object was recorded on the negative at the time of exposure. Lady Elizabeth Eastlake, a well respected Victorian photographer and commentator on photography, for example, in 1857 declared that the camera could but "...give evidence of facts, as minutely and impartially as, to our shame, only an unreasoning machine can give." ${ }^{\$ 2}$

To illustrate this prevalent preconception of the medium, consider the comparison of a sketch and photograph, both created on the North American Boundary Commission of 1872-75. This commission was a re-working of the survey of the 49th Parallel to assuage doubts that it had been "drawn” correctly. George Mercer Dawson, the survey's geologist, drew Watergate at Waterton Lake (fig. 6) in 1874, which provides a marvellous foil to the photograph taken at the same time by an unidentified member of the Royal Corps of Engineers, Waterfall North Corner of Waterton Lake: 4 Miles North of Boundary Line and 157 Miles West of Red River (fig. 7). While the intended purposes of these two works were quite different, they still serve to demonstrate the perceived inadequacy of artist's renderings. Dawson did not produce this sketch to be a scientific and topographical document; he drew it for his own benefit to be used as a basis for paintings when he had returned home. It is little more than a series of hastily drawn lines that, for all their

\footnotetext{
${ }^{42}$ Lady Elizabeth Eastlake, "Photography," Quarterly Review (1857). Reprinted in Classic Essays on Photography, Alan Trachtenberg, ed. (New Haven, 1980), 66.
} 
seeming deftness, only give the barest impression of the scene depicted. The photograph, by contrast, provides a wealth of topographical detail. Geological forms are clearly defined, the individual strata of the earth and the nature of vegetative growth are plainly evident. For Victorians, the seeming precision of the photograph would have made it a more valuable document than the sketch. For example, William and Mary Howitt, writers and early spiritualists, published a book in 1862 entitled Ruined Abbeys and Castles of Great Britain, that more than adequately demonstrates this premise. In the preface they state:

It appears to us a decided advance in the department of Topography thus to unite it to Photography. The reader is no longer left to suppose himself at the mercy of the imaginations, the caprices or the deficiencies of artists, but have before them the genuine presentment of the object under consideration. ${ }^{43}$

The lack of specificity evident in the sketch would have made it seem both inaccurate as well as generic, because the human hand, it was believed, was incapable of producing such clarity of detail.

During this positivist age, founded philosophically on the precepts of logic and empiricism, the belief by Victorians that the world could be physically measured, categorized, then neatly classified presupposed that "reality"-what was experienced through the senses-was a given, external entity. Positivist conceptions of reality, as espoused by Auguste Comte, the French philosopher who sought to apply scientific observation and methodology to the re-construction of society, directly opposed

\footnotetext{
${ }^{43}$ As quoted in David Harris, "Photography and Topography: Tintern Abbey," British Photography in the
} Nineteenth Century, Mike Weaver, ed. (Cambridge, 1989), 95. 
Romanticism, a philosophical discourse espoused by Immanuel Kant's epistemology that characterized the first half of the nineteenth century. As Victor Burgin argues in general terms in the introduction to his work, Thinking Photography, while Romanticism posited reality as something which is structured by the intellect-internal reflection being considered the path to knowledge of the world-Positivism reversed this relation. External reality was believed simply to exist, and thus was thought to be objective and independent of human prejudice. This inherently ordered entity was posited as the intellectual guide that people should use to structure thoughts and arguments about the world: ${ }^{44}$

...[T]he mind has given over the vain search after Absolute notion, the origin and destination of the universe, and the causes of phenomena, and applies itself to the study of their laws - that is, there invariable relations of succession and resemblance. Reason and observation, duly combined, are the means of this knowledge. ${ }^{45}$

Positivism, therefore, presumed reality as something physical, external to the self, which could be quantified and recorded. There was no Kantian "noumenal" world behind apparent physicality, nor was reality deemed to be a poor reflection of some higher Platonic ideal. Reality—-the physical world—was simply there.

It is not surprising then, that due to its seemingly indexical character-a "sign" which stands in a relation of proximity or causality to a particular object in a specific situation-photography gained primacy in nineteenth-century thought. Emerging, perhaps not coincidentally, at mid-century, it was inevitably conceived and utilized

\footnotetext{
${ }^{44}$ Victor Burgin, "Introduction," Thinking Photography, Victor Burgin, ed. (Houdmills, 1982), 10.

${ }^{45}$ Christopher G.A. Bryant, Positivism in Social Theory and Research (London, 1985), 29.
} 
within the intellectual boundaries of this time. Lady Eastlake, citing society's desire and need for "correct facts" declared that "[p]hotography is the purveyor of such knowledge to the world. She is the sworn witness of everything presented to her view." ${ }^{46}$ Photography's apparent ability to transcribe external reality directly and accurately-it was believed - fitted neatly within Positivism's philosophical precepts, and became the ideal tool for the Victorian quest to conquer the world intellectually (and otherwise). Furthermore, objectivity in photography was conditioned by a historical set of codes designed to represent reality. James Duncan, in his essay "Sites of Representation," traces this tendency to the mathematization of space through linear perspective by Brunelleschi and Alberti in the fifteenth century, with its premise of creating a "mimetic reproduction of the material world." ${ }^{47}$ Photography, then, can be viewed as an outgrowth of western perspectival systems with its images connoting the same qualities of pseudo-scientific truth and accuracy.

With respect to the discussion at hand, the indexical nature of photography verified how an object, person, or place actually appeared at some point in time because reality, as an external entity, was believed to be capable of being recorded. Because photography ultimately depended upon a physical referent,

...this physical presence is the origin or source of the possibility of an image and, consequently, the image stands as an index of the once physical presence. It is this indexical status which is the source of the authority of the image.... ${ }^{48}$

${ }^{46}$ Lady Eastlake, 65.

${ }^{47}$ James Duncan, "Sites of Representation," Place/Culture/Representation, James Duncan et al., eds. (London, 1993), 41.

${ }^{48}$ Derrick Price and Liz Wells, "Thinking About Photography," Photography: A Critical Introduction, Liz Wells, ed. (London, 1997), 51. 
Therefore, not only was the photograph a representation of a particular moment in time, it could actually substitute for direct physical experience with the object photographed. In other words, the photograph collapses the distance between signifier-the representation—and signified — the object represented. Sir David Brewster, a physicist with an acute interest in optics, writing in the North British Review of 1847, declared that photography enabled "homefaring" people:

...to scan the beauties and wonders of the globe, not in the fantastic or deceitful images of a hurried pencil, but in the very pictures which would have been painted on his own retina, were he magically transported to the scene. ${ }^{49}$

As Brewster asserts, photographs were believed in the nineteenth century to be facsimiles of the subject: they could present "reality" independently from the original object. In other words, photographs could act as authoritative proof, to verify empirically whatever was laid before the lens at the time of exposure. For imperialists, photographs could validate reports and clarify maps; hand-rendered sketches quickly lost significance for officials.

Staffage, as it will be demonstrated, works in tandem with this conceptualization as the photographing of these figures reinforced and even emphasized notions of reality and presence. Whereas photographs aided in bringing foreign places back to the homeland, staffage could act further to bridge the gap between the actual place photographed and the viewer. Figures - particularly white, male figures—provided vehicles through which European and Euro-Canadian viewers could comprehend the landscape photographed. 
They acted as more than referents to which these viewers could relate, but served to stand in for them. Staffage furnished a vicarious means for homebound imperialists for "being there." Understood in this manner, Lady Eastlake's "sworn witness" takes on very literal connotations. The viewer, through staffage, helped to authenticate the photograph. More significantly, staffage established a European presence in what were perceived to be uncivilized and seemingly empty — at least of any discernible European influences - tracts of land. While European figures humanized the landscape and made its exoticism more palatable to armchair tourists, it also served to verify the occupation of foreign lands. Photographing colonizers in situ, then sending these perceived slices of reality home to be viewed by officials and eventually the public, provided evidence of occupation. To put it another way, staffage visually reinforces the presumption that these areas were possessed and ultimately controlled by colonizers, and the authority of these beliefs rested upon the indexical nature of the photograph itself. Photography and staffage in expedition photographs reinforced each other: staffage acknowledged imperialist claims to ownership and power, while photography disseminated these claims in a medium that transformed fragmentary facts into truths.

\section{Imperial Landscapes: Using Staffage to Stake a Claim}

Within a colonial climate, the act of taking a photograph constitutes an act of political appropriation. Photographs and their dissemination presented the land visually to represent imperialist concerns-in order to establish colonial presence and claim control

\footnotetext{
${ }^{49}$ As quoted in Harris, 97.
} 
over the land. Staffage, a particularly effective method of implicitly claiming possession, became critical in these representations. Because they participated at the level of signification, staffage can not be dismissed as mere providers of scale-that is, as a documentary tool-but instead become discursive. To it put another way, because staffage figures participated in the narrative of a photograph, they become open to interpretation. This not to imply that colonizers simply have to stand in a landscape to claim ownership; often, what the camera captures them doing in the landscape is equally provocative.

Another example from the North American Boundary Commission-a photograph by the Corps of Royal Engineers entitled La Roche Percée-Five Miles North of Boundary and 253 Miles West of Red River (fig. 8) taken on September 10, 1873-illustrates this point. Located in the Souris Valley, near what is now Evetar, Saskatchewan, La Roche Percée was one of a series of sandstone pillars carved out by erosion and used by many surveys as a landmark. Its unusual form was also a source of fascination to indigenous inhabitants. Captain John Palliser, leader of the first survey of the Northwest sanctioned by the British government, remarked on August 21, 1857 that the "...Indians never pass the stone without making some offering to Manitou which to their minds it represents, such as rubbing vermilion on it, depositing beads, tobacco, or the like in the crevices." 50 The area around La Roche Percée was of particular interest to expeditioners as it was believed there were possibly deposits of coal present. The visible strata in these

\footnotetext{
${ }^{50}$ John Palliser, The Papers of the Palliser Expedition 1857-1860, Irene M. Spy, ed. (Toronto, 1968), 130.
} 
sandstone pillars exposed the geological history of the region, and aided in determining the validity of this belief.

In this photograph, we are not presented with a grand, sweeping, and sublime landscape, but instead with two figures standing amongst stubby grasses, intently studying this unusual rock formation that rises from the earth. Extensive visual penetration has been prohibited by these massive forms, creating a flattened, almost abstract image. However, the two engineers anchor the scene, making it comprehensible to Victorian viewers as well as establishing control over it. With their backs to the camera, their attention is on the "pierced rock" before them, presumably examining its geological features. Positivist impulses to catalogue and document the world coupled with imperial acquisitiveness serve to make this act of intense study a mode of territorial conquest. Objectifying the landscape made it a commodity capable of being consumed, controlled, and, therefore, owned. Showing geological formations as articles of study is a very direct way of established control over a landscape. In this case, investigations for coal deposits were a means of determining the area's suitability for settlement; further, subjecting them to "objective" study divested them of any quasi-religious connotations bestowed by local inhabitants, and distanced it from them. Scrutinizing them, determining their geological past so as to predict their future was ultimately a means of deciding their potential usefulness to the Empire. To do so, ownership of the land is implied.

Thus, by illustrating this rock as an object of rational study in addition to being of a spectacle of nature, there is a projected confidence that the land can be understood and therefore controlled. The two staffage figures make this act of symbolic appropriation 
explicit. In effect, they serve as markers of civilization; their careful study will make the Northwest suitable for human habitation. They order the scene, aesthetically and conceptually. On the one hand, they provide a focal point that clarifies the landscape for the viewer; on the other, their action of study ideologically organizes the scene by making it a scientific object for consumption. The connection between staffage figures and viewer also allows the audience to participate in this act of appropriation. Because the two engineers have their backs to the camera, they are divested of any individuality, and viewers can transpose themselves into the scene. Further, given the direct connection between image and referent, the photograph ultimately becomes a window through which the viewer has direct contact with the scene. The camera in La Roche Percée seems to have been positioned on a small rise, thus slightly elevating the camera's-and therefore the audience's-point of view. Perhaps an accident of circumstances, this heightened perspective gives the sense of "overseeing" the object under study, and thus emphasizing the viewers' perception of participating in its discovery and controlling its destiny. ${ }^{51}$

Staking claims of possession were not always so explicit. Staffage figures in exploratory photographs were not always British and Canadian expedition members; native figures were quite common in these photographs. However, the apparent physical absence of white Europeans and Eastern Canadians did not necessarily correlate to a lessening of colonial imperatives; these landscapes still acted as markers of imperial, cultural powers.

${ }^{51}$ For a more detailed discussion about the implications of perspective and "overseeing," see Catherine A. Lutz and Jane L. Collins Reading National Geographic (Chicago, 1993). 
Charles Gentile's complex yet evocative Spence's Bridge At the Confluence of the Nicola and Thompson Rivers, BC (fig. 9) of 1865 illustrates how native staffage figures could function in a colonial reading of a photograph. As such, it also demonstrates how visual cues of civilization - principally in the form of an inanimate object-worked to reinforce European appropriation of the land. Although this photograph was not taken under the auspices of a government sponsored survey, Gentile was by no means immune from imperialist influences. Gentile travelled extensively through the British Columbian interior during the 1860 s aware that his audience had an appetite for photographs of picturesque nature; specifically, for photographs demonstrating the civilizing progress of the colony.

On first inspection, Spence's Bridge appears to be a quintessential picturesque landscape. It is a deep, expansive view-quiet and still. The rugged height of the mountain gives a sense of grandeur to the scene, and contrasts to the flatness of the river in the foreground. The two native figures in the lower left initially only seem to add a touch of exoticism, as well as acting as repoussoir elements that enhance the sweeping depth of the landscape. However, other than these figures, there is little in the foreground for the camera to focus on; the apparent smoothness of the water leads the eye directly back into the mountainous background. Not only does this bypass the figures, it leads the viewer directly to a bridge that extends almost across the whole of the photograph. With the introduction of this European symbol of technology—bridge engineering - the entire dynamic of the photograph changes and becomes a visual statement proclaiming the progress of "civilization" in the West. Taken in 1865, this 
depicts a toll bridge built as part of the Cariboo Wagon Road constructed to open up the British interior during the 1860 s gold rush. It serves to mark the impact of European presence. The linear manner in which the bridge visually organizes the photograph can act as a reflection of how Europeans and Euro-Canadians physically re-organized the Northwest by breaking up vast areas into orderly segments. The presence of a bridge unequivocally stated that this area was under European control.

European imperial powers generally valorized industry, judging it as an outgrowth of Enlightenment rationalism. Technological developments which replaced man and animal, and apparently allowed them to overcome natural impediments were regarded as the yardstick against which the progress of civilization was measured. Bridges were particularly potent symbols of modern engineering. Their immense physical presence coupled with its seeming ability to shrink distances succinctly demonstrated in visual terms the impact of technology onto nature. For colonizers, building bridges in new territories demonstrated the ideological subjugation of the land to European authority. Imposing structures on the land was an obvious sign of their presence which thereby indicated their capacity to support settlement.

A comparison to Charles Horetzky's Indian Suspension Bridge Over the Wotsonqua River Near Hazelton, BC (fig. 10) of 1872, taken while on the Canadian Pacific Railway Survey of that year, illustrates this concept. Both of these photographs show a scene depicting a bridge spanning a void over a body of water, yet each photograph creates quite a different impression. Between two steep, snow-covered, rocky banks, is a narrow bridge made entirely from wood. Steam rising from the river veils the treed landscape 
behind and makes the "void" underneath the bridge that much more apparent. Horetzky's image is quite atmospheric, evoking a mood of solitude and melancholy that is the result not only from his massing of lights and darks, but also due to the perceived dilapidation of the bridge itself. The close view of the bridge makes its construction from natural materials quite evident. Dangling ties and an apparent lack of consistent measurement in branches makes its "sagging" a seeming testimony to its imminent collapse. Horetzky's description of this structure in his 1874 book Canada on the Pacific makes this perception quite clear:
About three miles from Hazelton, and three hundred feet down the rocky bed of the Wotsonqua, there is a large Indian ranche, or village, of some twenty houses. ... Immediately in front of it the Indians have thrown a suspension bridge across the rocky chasm, through which the waters of the Wotsonqua rush with impetuous haste towards the Skeena. The bridge is built entirely of wood, fastened together by withes and branches; its height above the roaring water beneath is fifty feet, and it sways under the weight of a man, to try even the nerves of a Blondin. ${ }^{52}$

The perceived crudity of the Wotsonqua River construction contrasts greatly to Gentile's photograph. Here, the viewer is distanced from the bridge, but this served to demonstrate the great space it seems to span with ease. Regularity of forms and an emphasis on the horizontal bestows upon Spence's Bridge an impression of sturdiness and strength. As the product of European science and technology, the ability of this bridge to overcome nature's obstacles seemed to prove the superiority of European industry and thus illustrate the presence of civilization in the landscape-indeed, of technology dominating nature. The Indian Suspension Bridge, made from wood, not iron, is presented as a product of

\footnotetext{
${ }^{52}$ Charles Horetzky, Canada on the Pacific (Montreal, 1874), 103-4.
} 
nature, not modern European technology. As such, it was deemed inferior, and testified to the need of a civilizing influence for the rawness of its construction implied a colonial absence.

Although the bridge in Gentile's photograph has not been monumentalized, neither has it been dominated by the landscape. It progresses unimpeded across the scene, demonstrating the successful incursion of European technology, and thereby demonstrating the progress of civilization in the area. In other words, the presence of a bridge changed how the landscape was interpreted because it modified nature, literally and conceptually. Therefore, Spence's Bridge becomes less of a picturesque view of wilderness than a visual statement detailing the progress of civilization in the Northwest.

The implied impact of European technology also contrasts markedly to the two native figures in Gentile's image; they again confirm the degree of progress in an area. Readings of these figures depends on their visual context. They could, on one hand, symbolize a lack of civilization and therefore justify the spread of imperial institutions and Christian morals into a region; or, on the other, they could illustrate the degree to which civilization had already penetrated the region. Spence's Bridge seems to illustrate the latter. Their distance from the camera obstructs any close reading of their faces and dress, consequently depriving them of their individuality; they are presented as "types" rather than specific people. Seated quietly, the two figures pose stiffly and awkwardly; their placement in the scene seems to detach them from their surrounding environs. Placed on rocks that are not visually connected to any other part of the landscape, they are physically distanced from the land. Taken together, these aspects served to make the 
native figures seem passive; they have been divested of their ability to endanger and oppose, and their juxtaposition to the railway heightens the sense of colonial conquest. It also visually encapsulates how far Europeans have come as a society, acting to illustrate a perceived linear narrative of European progress from native to technology: "From the progress of science, he reads the progress of mankind as it gained increasing control of the environment and man himself." ${ }^{53}$ Therefore, although Western figures are not physically present in the scene, their ability to impress their values upon the land is visually apparent due to the presence of the bridge. The landscape has been re-fashioned to better reflect colonial ideology, and its pictorial format "naturalizes a cultural and social construction, representing an artificial world as if it were simply given and inevitable." 54 Staffage, in this case, has been used to demonstrate the success of their civilizing mission.

\section{In Summary...}

As demonstrated in these examples, the photograph is not merely a representation of a landscape but rather an encapsulation of a cultural ideology. These works bear the imprints of colonial belief that European and Euro-Canadian influences could tame both indigenous inhabitants and nature, thus bringing order to what they perceived as an unruly wilderness. Staffage served as a visual symbol of colonial presence, and further instructed how the viewer was to read the photograph. In La Roche Percée, staffage acted

\footnotetext{
${ }^{53}$ Arline Reilein Stanley, Auguste Comte (Boston, 1981), 60.

${ }^{54}$ W.J.T. Mitchell, "Introduction," Landscape and Power (Chicago, 1994), 2.
} 
as a visual manifestation of the colonial goal to consume the contents of the spaces they sought to occupy, using knowledge as a means to control and ultimately possess the land. In Spence's Bridge, staffage was utilized to illustrate the progress of civilization in the West, and the imposition of a physical yet ideological structure was another way to appropriate the land. Nonetheless, these photographs were implied with a sense of authority rooted in the photographs indexical character. They provided proof of imperial presence in the land although, as we have seen, these photographs are products of social, semiotic processes rather than that of unproblematic empiricism. ${ }^{55}$ If a photograph in general served to collapse the space between reality and referent, staffage was equally effective in collapsing gaps between referent and viewer. Because photographs were believed to offer authentic encounters with distant objects, viewing a photograph became an analogue for direct observation of the original object. This deflation of space and time between object and image is how the photograph became not just a twodimensional image, but a window to experience the world. ${ }^{56}$

\footnotetext{
${ }^{55}$ John Tagg, The Burden of Representation (Minneapolis, 1988), 4.

${ }^{56}$ Jennifer Green-Lewis, Framing the Victorians (Ithaca, 1996), 25.
} 


\section{From Wasteland to Breadbasket: Geography, Photography, and the "Northwest"}

Whereas the previous chapter discussed how Canadian expansionism at mid-century was impelled by current colonial ideologies, this chapter endeavours to examine the more practical aspects of this phenomenon. Although there had been a European presence in British North America for centuries, its interior largely remained a terra incognita. Thus, it is necessary to investigate both the pre-existing conceptions of the Northwest, as well as the metamorphosis of these views as the region's potential utility was re-assessed. Moving towards terra cognita, however, was no easy task, and demanded an intense reexamination of the land, and lead to one of the most intensive periods of exploration in Canada's history. Consequently, the role geography played in this "revelation" shall also be considered, paying specific attention to the emerging use of photography as a means of documentation, and how photography was used as a tool of intellectual conquest by imperialists. In this context, as outlined in the introduction, staffage becomes particularly significant in these images as it plays a key role in the conceptual transfiguration of the Northwest, as well as underscoring imperial assumptions towards the land.

\section{Conceptions of the Northwest: Obstacles to Settlement}

By 1845 the Northwest remained isolated from the rest of the British North America, 
virtually devoid of European influence. It was largely under the control of the Hudson's Bay Company, an institution more concerned with trade and renewing its license from Britain than with outright settlement. As a result, the Northwest was sparsely populated, largely by native peoples, Métis trappers, missionaries, and fur company employees who operated trading posts throughout the region. Settlers-that is, settlers of European descent — were far and few between, and the majority of farms present were worked by Company employees to supplement food stores rather than as enterprises in and of themselves. Profit was pursued in furs, not in crops, nor lumber, nor minerals.

Nonetheless, it would be incorrect to imply that the Northwest was "undiscovered." Indeed, as Evitar Zerubavel argues in Terra Cognita, "discover" is a conflicted yet highly evocative term, for it implies that a particular region existed as a void preceding its "discovery."' Conceiving lands as "empty" of European presence or influence justified expansionists acquisition of territory for they believed no one had a prior claim to them, thereby negating indigenous occupation of these regions. With respect to Canada's Northwest, it took several centuries for this ideology to flourish. Its existence, however vague in form, had been known since the seventeenth century. But this had not been good news to Europeans. Early explorations of Canada were not undertaken due to any intrinsic valued perceived in the land mass itself. Instead, until the mid-eighteenth century, Canada was considered an obstacle, an impediment to be overcome in the search for an easily navigable trade route to the Orient, and exploration of the interior

\footnotetext{
${ }^{1}$ Evitar Zerubavel, Terra Cognita (New Brunswick, 1992), 2.
} 
was undertaken only in the hopes of discovering a means to traverse it. ${ }^{2}$ Maps, a "coalition of fact and design," reflect the sensibilities of the age which created them, ${ }^{3}$ and early maps of Canada's centre were little more than theories which mirrored the desire that the interior would yield a chain of waterways that would traverse the whole of the continent. Joseph Delisle and Phillip Bauche's Carte des Nouvelles Découvertes au Nord de la Mer du Sud (fig. 11) of 1752 makes this desire most explicit. In this map, a series of rivers and lakes cross the whole country, culminating in the "Mer ou Baye de l'Ouest"_a mythical inland sea believed to empty into the Pacific Ocean. Although this sea was indeed fictional - it was created in 1708 by the editor of the Monthly Miscellany or Memoirs for the Curious for a series of stories about the adventures of an equally fictional Admiral Bartholomew de Fonte-Delisle and Bauche's map gave it geographical credibility, and fostered a confusion that lasted for decades. ${ }^{4}$

\footnotetext{
${ }^{2}$ Mary Javorski, The Canadian West Discovered. (Calgary, 1983), 8. It is interesting to note that early conceptions of Canada's transcontinental railway were conceived in similar terms. Robert Carmichael. Smith, in a letter to Earl Grey in 1850, envisioned his proposed railway running to the Pacific coast, trading "the produce of the West in exchange for the riches of the East." Letter (London, 1850), 5. The Northwest, instead of an impediment, was now viewed as a giant bridge that offered the quickest route to the wealth of Asia. Millington Henry Synge, Great Britain One Empire (London, 1852), 56. Bypassing the interior and conceiving it only in terms of trade with the Orient may reflect, as Doug Owram points out, a persistent lack of faith in the Northwest's ability to support agriculture and industry. Promise of Eden (Toronto, 2nd ed. 1992), 49.

${ }^{3}$ Javorski, 6.

${ }^{4}$ Ibid., 21. William Francis Butler, in his popular adventure novel The Great Lone Land of 1872, reinforces this perception, although by this time there had been several surveys undertaken in the Northwest, but with a curious literality that is quite striking in its language. Referring to these early maps of Canada's West, Butler declares that,

...the geographers of that period erred only in the description of ocean which they placed in the central continent, for an ocean there is.... But the ocean is one of grass, and the shores are the crests of mountain ranges, and the dark pine forests of sub-Arctic regions. The great ocean itself does not present more infinite variety than does this prairie-ocean of which we speak. In winter, a dazzling surface of purest snow; in early summer, a vast expanse of grass and pale pink roses; in autumn too often a wild sea of raging fire.

William Butler, The Great Lone Land (London, 1872), 199.
} 
Even after resources of fish, whale oil, and furs began to draw more Europeans inland, their interest in the interior was still only incidental. Explorations were undertaken to map trade routes and to search for new sources of furs rather than to study the land itself. Furthermore, most of these explorers did not remain in North America. They observed the land, noted their findings, then returned to Europe to complete their journals and official reports. Whatever "discoveries" about the interior that arose were quickly exported; this knowledge did not stay in Canada. Competition between fur companies further impeded the dissemination this information. Maps of hunting grounds and trade routes were highly valued commodities kept in strictest confidence by fur company employees.

However, how the land appeared also had a grave impact upon considerations of its functionality. Although the Northwest was geographically connected to eastern areas of Canada - it was, after all, part of the same continent-for many people it may have seemed as foreign and distant as Africa was held to be. As Jeffery S. Murray has argued in his article "The Map Makers," it was the nature-the aesthetic —of the landscape form itself that curtailed Euro-Canadian interest in this area..$^{5}$ Humphrey Lloyd Hime's photograph The Prairie Looking West (fig. 11), taken on the 1858 Assiniboine and Saskatchewan Exploring Expedition, the first Canadian expedition into the Northwest, for example, must have been a shock to those who had never experienced the Northwest before. Europeans and Eastern Canadians accustomed to gentler, treed landscapes likely found the stark, unrelenting flatness of this scene uncomfortably alien. The blank sky 
seemed to mirror the equally blank Prairie, and this apparent lack of variety in geological features, or its oppressive uniformity, seemed to offer little prospect for settlement. The skull in the foreground is the only other object seen in this landscape and its connotations were hardly reassuring. While operating on one level as a memento mori device, it could have also been read quite literally as a warning illustrating the fate of those foolish enough to venture there. Overall, it was considered, according to David Thompson in 1801, a fur company employee and cartographer, a desolate, featureless wasteland "given by Providence to the Red men forever."

The flatness of the grassy plains coupled with the scarcity of trees lead people to believe that the prairies were an arid, barren desert. It was reasoned, logically perhaps, that if the soil could not support the growth of trees, it certainly could not support a large-scale agricultural project.' Their absence was equated with a sterile, hostile environment as, according to a Toronto magazine, "no friendly expanse of forest will shelter them from the full sweep of the famine borne wind, and no useful timber trees afford them their winter's firing." ${ }^{\prime \prime}$ The jagged heights of the Rockies were equally disconcerting. Although they were richly forested, thick undergrowth made them virtually impenetrable, in addition to being strewn with swamps, and difficult to access. For explorers and travellers, daily progress off the beaten track-provided there was a trail, however faint, to follow_was measured in yards, not miles. On the 1871 Geological Survey of Canada, Alfred Selwyn and his party, enroute to Jasper House

\footnotetext{
5 Jeffery S. Murray, "The Map Makers," The Beaver (Feb/Mar. 1989), 14.

${ }^{6}$ As quoted in Ronald Rees, Land of Earth and Sky (Saskatoon, 1984), 3.
} 
along the Thompson River, at one time were only able to carve out four and a half miles of trail in seven days because the trees were

prostrate, reclining, horizontal, propped up at different angles, timber of every size, in every state of decay, in every possible condition, entangled in every possible combination. ${ }^{9}$

Taken together, these features combined to create a region that appeared "uncultivable, unsettleable, and inhospitable." ${ }^{10}$ To Europeans accustomed to gentler landscapes of green hills, copses of trees, and verdant pastures dotted with sheep, the Northwestern landscape was "devoid of the familiar visual symbols that lured pioneers to other parts of North America." ${ }^{11}$ As late as 1848, when the agricultural potential of the Northwest was beginning to be considered, Ben Hawkes, Parliamentary Under Secretary in Westminster, disparaged the settlement of such a "dreary territory." ${ }^{12}$

Reactions to the land were conditioned not only by what they saw, but also by what they expected to see. The very lack of familiar topographical forms which defined the Northwest ultimately made it unappealing. Educated European explorers' and military officers' perceptions of the landscape were, unsurprisingly, filtered through their cultural expectations. Specifically, expectations were measured against the learned nineteenth-

\footnotetext{
${ }^{7}$ Owram, 14.

${ }^{8}$ Unknown, Anglo-American Magazine (Sept. 1852). As quoted in Owram, 14.

${ }^{9}$ In his journal Benjamin Baltzly used this quote drawn from Viscount Milton and William Butler Cheadle's The North West Passage by Land which detailed their overland journey in 1861-62. Alfred Selwyn, leader of the 1871 Geological Survey of Canada expedition, planned to follow the same route through the mountains that Milton and Cheadle had, only in reverse. However, a late start and bad weather restricted this ambition. Both Selwyn and Baltzly took The North West Passage by Land to act as a kind of guide, and both quoted from it frequently. Andrew J. Birrell, Benjamin Baltzly: Photographs $\mathcal{E}$ Journal of an Expedition Through British Columbia. (Toronto, 1978), 13-14.

${ }^{10}$ I.S. MacLaren, "Aesthetic Mappings of the West by the Palliser and Hind Expeditions, 1857-1859," Studies in Canadian Literature 10.1-2 (1985): 36.

${ }^{11}$ Murray, 14.
} 
century aesthetics of the picturesque and the sublime-a "habit" defined by "viewing and criticizing nature as if it were an infinite series of more or less well composed subjects for paintings."13 Put simply, while these two different aesthetics corresponded to preconceived landscape "types," the psychological impact that landscapes had upon the viewer were also critical in their characterizations.

Ian MacLaren has argued, in his article "Aesthetic Mappings of the West by the Palliser and Hind Survey Expeditions," that the regions advocated for settlement by Palliser and Hind were those that conformed to the picturesque aesthetic of "undulating, well-watered parkland of delimited scope and scale, and exhibiting only moderately-sized geographical features." 14 In other words, it was those areas that most resembled the landscapes of the home land-Britain - that were deemed fit for settlement. Palliser, when writing about the area surrounding the North Saskatchewan River between Rocky Mountain House and Carlton House in 1858, recommended this area for settlement, describing it as a "partially wooded country, abounding in lakes and rich natural pasturage, in some parts rivaling the finest part scenery of our own country." ${ }^{15}$ As MacLaren contends, since the area resembles an English parkland, those who farmed it "may live like those Englishmen possessed of such parkland in their own country." ${ }_{16}$ Also, according to the expedition's botanist Eugene Bourgeau, only stewardship was required

\footnotetext{
${ }^{12}$ As quoted in Rees, 3.

${ }^{13}$ Robert Stacey, "From 'Icy Picture' to 'Extensive Prospect': The Panorama of Rupert's Land and the Far North in the Artist's eye, 1170-1870," Rupert's Land: A Cultural Tapestry, Richard C. Davis, ed. (Waterloo, 1988), 147.

${ }^{14}$ MacLaren, 26.

${ }^{15}$ John Palliser, The Papers of Palliser Expedition 1857-1869, Irene M. Spry, ed. and introd. (Toronto, 1968), 538.
} 
for the land to produce abundantly. ${ }^{17}$ Thus, in those areas found to be picturesque, a life of ease, comfort, and even wealth was predicted. These projections also served to reinforce the colonial project of simply imprinting the mother country onto the colony, as discussed in the preceding chapter. Because certain areas closely resembled landscapes of England, hegemony in geographical forms was seen readily to give way to hegemony in political and cultural forms as well. A British-looking landscape was bound to promote the flourishing of British ideals.

Sublime landscapes of "vertical and horizontal vastness," such as the dramatic terrains and grand forms of the Prairies and mountains, were judged as beautiful to the eye and perhaps even uplifting to soul. When Henry Youle Hind, leader of the 1858 Assiniboine and Saskatchewan Exploring Expedition, came to the Winnipeg River on August 27th, he found it to be aesthetically exhilarating:

Some of the falls and rapids present the wildest and most picturesque scenery, displaying every variety of tumultuous cascade, with foaming rapids, treacherous eddies, and huge swelling waves, rising massive and green over hidden rocks. The pencil of a skillful artist may succeed in conveying an impression of the beauty and grandeur which belong to the cascades and rapids of the Winnipeg, but neither sketch nor language can portray the astonishing variety they present under different aspects; in the grey dawn of morning, or rose-coloured by the setting sun, or flashing in the brightness of the noon day, or silvered by the soft light of the moon..$^{18}$

Nonetheless, many areas, despite their beauties were denounced as unsuitable for human habitation because they did not conform to familiar landscapes. As MacLaren points out, the risk in applying the picturesque aesthetic "was to imply that the land was therefore

\footnotetext{
${ }^{16}$ MacLaren, 32.

${ }^{17}$ Ibid., 33.
} 
ideal for residence by humans." ${ }^{19}$ Hind, in his work Narrative of the Canadian Red River Exploring Expedition of 1857 and of the Assiniboine and Saskatchewan Exploring Expedition of 1858, reminds his readers that although "rock, water, and a few bushels of soil" could look appealing, this did not make those lands eminently habitable. ${ }^{20}$ As he writes about the perceived quality of land encountered until that point: "...the general features of the country maintained an appearance of hopeless sterility, and inhospitable seclusion. ${ }^{21}$

Palliser's Triangle, ${ }^{22}$ a large, ultimately fictitious geographical area surrounding the Red Deer and the South Saskatchewan Rivers (fig. 13) described by Palliser as a barren wasteland consisting of broken ground and worthless soil, is the epitome of an aesthetic response conditioning the perceived value of the land. Because this area of grasslands did not conform to the picturesque aesthetic, it was found to be arid and hostile—unsuitable for settlement-although the Triangle roughly corresponds to what is now known as the breadbasket of Canada. ${ }^{23}$ Thus, since the land did not fulfill predetermined criteria of what fecundity should look like, this whole area was considered a desert. With respect to the colonial project, it is not surprising that interest in the Northwest did not exist. For centuries, it was characterized by the same sweeping generalizations of aridity, barrenness, and flatness. Because the land did not conform to a predetermined British

\footnotetext{
${ }^{18}$ Henry Youle Hind, Narrative of the Canadian Red River Exploring Expedition of 1857 and of the Assiniboine and Saskatchewan Exploring Expedition of 1858 (London, Vol. 1. 1860), 106-107.

${ }^{19}$ MacLaren, 43.

${ }^{20} \mathrm{Ibid}$.

${ }^{21}$ Hind, 110.

22 Palliser's Triangle was a 16,000 square mile area believed to be formed by the 49th Parallel between 100 and 114 degrees longitude west for its base, and its apex was thought to extend to the 52nd Parallel. Owram points out that both Palliser and Hind believed this region to be an northerly extension of The Great American Desert phenomenon in the United States. Owram, 67-68.

${ }^{23}$ MacLaren, 36.
} 
ideal-that is, it was difficult to "reproduce" the mother country in these topographically foreign areas—colonial interest faded into apathy.

However, to be fair, it is not entirely surprising that preconceptions about the Northwest were overwhelmingly negative if one considers where early descriptions originated. As R. Douglas Francis writes in his article "The Ideal and the Real," this area was primarily under the providence of fur companies who were predisposed to view the territory in the context of its fur-trade potential as opposed to its agricultural capabilities. Indeed, agriculture and fur trading were incompatible enterprises as the former destroyed the resources required to foster the continued growth of the latter. Hence, any agricultural potential perceived in the land was downplayed. ${ }^{24}$ However, very little land suitable for farming was ever reported as fur traders tended to confine their explorations to the northern regions of the interior where game was the most plentiful. For example, a typical fur-trade route ran from York Factory, up the Nelson River to Norway House and Cumberland House, and north to the Churchill River. This path was almost completely limited to the rugged Canadian Shield, so Company employees would not have encountered any land suitable for agriculture. ${ }^{25}$ Moreover, the economic dependence on the Northwest as a fur-rich territory was such that agricultural development was considered detrimental to the prosperity of both Canada and the Empire.

The majority of people who had been in the Northwest were therefore largely confined to its northern region; their-and others'-knowledge of the whole area were

\footnotetext{
${ }^{24}$ R. Douglas Francis, "The Ideal and The Real: The Image of the Canadian West in the Settlement Period,” Rupert's Land: A Cultural Tapestry, Richard C. Davis, ed. (Waterloo, 1988), 255.
} 
based on this one small part of it. Even those who penetrated the Prairies quickly became disenchanted with what they encountered. Again, Europeans accustomed to landscapes of abundant vegetation could scarcely comprehend that an area lacking in trees and shrubbery could be considered suitable for agriculture and settlement. ${ }^{26}$ George Nelson, a North West Company officer and self-styled adventurer, for example, when writing about the region around Lake Winnipeg in 1811-12, declared that it presented "a picture vastly more dismal than the far famed Siberia. ...[E]very object conveyed the idea of barrenness, solitude \& wretchedness." ${ }^{27}$ This conception of the Northwest as a hinterland was so pervasive that in 1849 , when a Major John Griffiths wrote to the Colonial Secretary on the possibility of settling the Hudson's Bay territories, his reaction was one of disbelief: "How a country, where there is eight months of winter, and snow on the ground for the whole period, is to be opened up, is to me a riddle." ${ }^{\prime 28}$

Conceptualizations aside, there was also a very practical reason why the Northwest remained isolated from Eastern Canada for so long. While geography united the territories on the map, topography actually served to insulate the Northwest and block the westward flow of settlers. A representative for the Colonial Office once declared that the Northwest was "more difficult to reach than any existing colony of ours on the face of the globe. ${ }^{229}$ Mountains on the west coast could be traversed, but not easily. The arctic

\footnotetext{
${ }^{25}$ Ibid.

${ }^{26}$ Ibid.

${ }^{27}$ Silvia van Kirk, “'This Rascally and Ungrateful Country': George Nelson's Response to Rupert's Land," Rupert's Land: A Cultural Tapestry, Richard C. Davis, ed. (Waterloo, 1988), 119.

${ }^{28}$ Percy Ford, Selected List of British Parliamentary Papers. (Shannon, Rev. ed. 1969), vol. 18, 1849 Session, 406, Griffiths to Earl Grey, 18 Jan. 1849.

${ }^{29}$ Rees, 3.
} 
and sub-arctic regions to the north posed the same problem, and was further hindered by its severe climate. It was the Canadian Shield to the east, however, which presented the greatest obstacle. Between the plains and the nearest eastern colony was a thousand mile marsh that was nearly impenetrable. Above the Great Lakes, "[j]agged outcroppings of rock, quaking, sucking 'muskeg' in the hollows; forest and bush as tangled as any jungle; lakes scattered like pockmarks every few miles" ${ }^{30}$ hampered the westward flow of travelers and settlers alike. John Palliser stressed in his expedition report for the British government in 1858 , that Canadians lacked a clear road to the west through their own territory, citing that the only practical route east of Red River was to go around the Great Lakes ${ }^{31}$ — through the United States—which was hardly convenient or desired.

\section{Reconsiderations of the Northwest}

As there was no comprehensive account of the interior after centuries of European "possession" and what was known of the area was deemed far from suitable for colonization, why did there arise a compulsion at mid-century to document it with settlement in mind? As outlined in the previous chapter, a heightened imperial sensibility lead to a growing thirst for land that would in turn, correspond to an increase in Canada's prosperity, imperial affiliations, and status within the British Empire. However, there were also more practical events which made this need acute.

\footnotetext{
${ }^{30}$ Douglas Hill, The Opening of the Canadian West (New York, 1967), 61.

${ }^{31}$ Palliser, The Papers of the Palliser Expedition, 499-500.
} 
Previously, Eastern Canada had a limited concern for what laid beyond its borders, but during the 1840s, its interest — as well as that of British politicians—was peaked by the Oregon “dispute." By 1821, the Hudson's Bay Company (HBC), by decree of an Act of the British Parliament, had exclusive control, but not ownership, of trade in all unsettled parts in North America, specifically the Athabaska and Mackenzie regions; this effectively constituted a monopoly. The United States, however, also claimed equal rights to the "fur-rich" territory called "Old Oregon," comprised of the present states of Washington, Oregon, part of Idaho and Montana, and much of the present province of British Columbia. Americans, as historian Douglas Hill points out in his book The Opening of the Canadian West, paid little attention to British trade rights, and persisted in hunting, and more significantly, settling in Old Oregon. ${ }^{32}$

It was not until the 1840s, when American settlers began to flood the Oregon region and demanded that Washington make Oregon an American territory that Britain began to worry. U.S. President James Polk's aggressive expansionist campaign for territorial concessions-epitomized by his battle cry "Fifty-Four Forty or Fight," indicating the latitude to which he wanted the American border extended (fig. 14)-brought the two nations close to war. Under such pressure, it became obvious that the HBC was not strong enough to act as guardian of British interests in the Northwest. ${ }^{33}$ The Company lacked the numbers of settlers needed to counteract American presence, and they actually lacked the political authority necessary to impose British institutional ideals on

\footnotetext{
${ }^{32}$ Hill, 49.

${ }^{33}$ Owram, 28.
} 
the region. Their mandate was commercial, not colonial. The HBC had been attempting to lure settlers into the coastal regions around Puget Sound and the Cowlitz Rivers to work farms expressly established to supply produce for posts along the coast, but the handful of people who did come were negligible in comparison to the in-pouring of Americans. Consequently, in 1848 the British government conceded to many of the Americans' demands, and the international border was extended along the whole of the 49th Parallel to the Pacific Ocean, resulting in the loss of the Columbia Valley to the United States. On paper, it may appear that British and American interests had been defined geographically, but in actuality, the 49th Parallel-a mere line on a mapseemed to offer little protection from the United States' self-professed "manifest destiny." All those unsettled, and therefore unclaimed, tracts of HBC territory must have seemed irresistible to American frontiersmen.

The Company-and Britain-had reason to worry. By 1848 , Oregon had gained territorial status, and there was a fear that the trickle of Americans into Canada's Northwest might become a flood. Early on, only about one hundred arrived each year; but by 1843 1,000 Americans moved onto British territory per year; by 1845, their number had swelled to $3,000 \cdot{ }^{34}$ By sheer population alone, they could theoretically claim the area by default. However, the HBC could do little to stem the tide of squatters; it had only a trading license, not the chartered rights of a sovereign nation. It became clear that British occupation of the land was necessary if Britain was going to retain the territory. Thus, while the region's agricultural and commercial potential was still under debate, 
settlement of the Northwest was not being advocated primarily for this purpose-this was only a consequence. Settlement was needed in order to protect British land claims, as well as to preserve British ideological influence in these areas and avert fostering "republican" ones through simple neglect. John A. Macdonald put it most succinctly, expressing both the need for settlement as well as eastern Canada's wariness of the region:

I would be quite willing, personally, to leave that whole country a wilderness for the next half-century, but I fear that if Englishmen do not go there, Yankees will. ${ }^{35}$

This situation was paralleled in Red River, found in present day Manitoba, where Americans in Minnesota hungrily eyed the unsettled surrounding environs in their own territory as well as those in British Canada. A Minnesotan named J.W. Taylor-called "Saskatchewan" due to his expansionist ambitions-boldly declared his state's future prospects were "continental in their grandeur." ${ }^{36}$ By the early 1860s, as Minnesotan settlements approached the border, the annexation of Red River, which was already dependent on American goods and trade, seemed almost inevitable. However, their advance was stayed by the outbreak of the American Civil War, which drew men and resources away from the frontier, and by the massacres by the Sioux nation which drove out many settlers from Minnesota and Dakota. Nonetheless, the message was clear: if the British would not settle the Northwest, the Americans would.

\footnotetext{
${ }^{34}$ Hill, 50.

${ }^{35}$ As quoted in Hill, 58.

${ }^{36}$ Ibid., 56.
} 
With Americans pounding at the gate, there were probably many in eastern Canada who wondered what the fuss was all about. Generations had considered the Northwest little more than a barren hinterland best left to trappers and native peoples. However, there were individuals who foresaw a greater destiny for the Northwest. George Brown, Reform politician and editor of the Toronto Globe, was such a person. He had acquired an interest in the Northwest during the Oregon dispute and campaigned vigorously against the HBC's monopoly. An "indefatigable booster of Canada West," ${ }^{37}$ he believed the future of his province lay in its connection to the Northwest, particularly a colonized Northwest. Steamers had been, by this time, traversing the Great Lakes from Toronto to Lake Superior, and Brown reasoned that if the Northwest's resources were going to be harvested, they would travel this route and financially benefit Ontario. Although his view included little in the way of actually cultivating the Northwest, and he had little concrete evidence to support his claims, there was implied in his vision a vastness of untapped resources and immense tracts of land to be exploited. During the 1840s though, Brown was one of the few who held such a favourable view of the Northwest's prospects.

By 1856, however, expansionism seemed both advantageous and essential. The intervening period witnessed tremendous growth in Canada. The population had swelled through immigration and a high birth rate, and the flourishing railway system fostered the development of urban centres, manufacturers, and entrepreneurs. Canada was beginning to outgrow its image as a backwoods colony. But there was a problem: a lack of

${ }^{37}$ Ibid., 58. In 1840 Upper and Lower Canada had been united most unhappily, and may people continued to view the country as two fold. 
cultivable land. By 1855, the last tract of "wild" land on the western-most part of Canada West had been sold, and the Canadian Shield limited further expansion. Confinement and a lack of inducements for immigrants became the biggest fears of Canadians. The solution quickly became obvious. Only possession of the Northwest would forestall economic and political stagnation, and its sheer size inspired dreams of a grand and prosperous future, although there was little to no factual data to sustain these aspirations, and despite a continued wariness of the region.

If overcoming a generalized fear of the Northwest was one obstacle to be overcome in order to facilitate settlement, the Hudson's Bay Company was the other. Indeed, if the Northwest was ever to become part of Canadian territory, these lands had to be wrested from the Company's grasp. Britain possessed this area, but legally it was controlled by the Company who had established their own administration for overseeing it. The HBC lacked any real political authority; nonetheless its influence in such matters was considerable. It had attained a monopoly over the entire interior in 1821, and by an Act of Parliament, had its license successfully renewed in 1843 . However, during the 1850 s when the HBC sought a second renewal, American encroachments and a newly awakened interest in the region forced a reappraisal of the HBC's status.

Once seen as only the means to enterprise in the Northwest, fur-trading and furtrading companies were now seen as an "obstruction to the colonizing spirit." ${ }^{138}$ Many Canadians, such as Allan MacDonell, accused the HBC of deliberately misleading the Canadian public by perpetuating the image of the Northwest as sterile and desolate so as 
to make people believe that the country was "unfitted for civilization, and debased by nature from ever benefiting by its humanizing efforts." ${ }^{39}$ While somewhat conspiratorial in nature, this argument may have had some basis in fact. In 1857, a Select Committee was set up by the British Parliament to examine the ramifications of a monopolistic furtrading company, and during the course of proceedings, the issue of whether the interior was capable of agriculture came up for debate. Sir George Simpson, Governor of Rupert's Land, flatly stated, "I do not think that any part of the Hudson's Bay territory is well adapted to settlement," citing "poverty of the soil" and a "rigorous climate" as evidence of his assertion. ${ }^{40}$ However, Simpson's own words served to contradict him. Ten years earlier, he had written a book entitled Overland Journey in which he had described an area of southwestern Manitoba as "the fertile shore of the spacious lakes" and predicted that the Rainy River would someday be "crowded [with] steamboats on its bosom and prosperous towns on its borders." Caught, Simpson conceded that there may be a cultivable "strip of land," but the remainder was "deep morasses which never thaw." ${ }^{11}$ The Committee was not convinced. Offered as further proof of Simpson's complicity, Alexander Kennedy Isbister, a former Métis HBC employee, claimed to have grown corn as far north as Fort Norman near the Arctic Circle on the Mackenzie River. ${ }^{42}$

\footnotetext{
${ }^{38}$ A.K. Isbister. Ibid., 59.

${ }^{39}$ Globe, 2 Sept. 1856.

${ }^{40}$ George Simpson. As quoted in Hill, 59.

${ }^{41}$ Ibid.

${ }^{42}$ Ibid.
} 
As Doug Owram has argued, the HBC had no viable defense since expansionists "couched their arguments in terms of universally desirable principles. ${ }^{43}$ Because opening the Northwest was to be in the name of progress, "that progress would be to the benefit of the whole Empire and, for that matter, all of humanity." ${ }^{\prime 4}$ To quote expansionist Alexander Morris from an 1856 speech:

Imperial as well as colonial interests urgently demand that opening up of that vast stretch of rich agricultural territory...those vast prairies, covered with the rankest luxuriance of vegetation, [hold] out to settlers rich inducements to go in and possess the land. Should such a "Paradise of fertility" as this remain longer locked up? Will the gathering of a few peltries compensate for the withdrawal of such a region from the industry of our race? Assuredly not. ${ }^{45}$

Moreover, it was felt that Canadians had a right to partake in the economic development of the Northwest even if it became known that not a single shaft of wheat could be grown. A mercantile, monopolistic empire had little chance in overcoming such imperatives. It was hardly surprising then when the 1857 Select Committee came down strongly on the side of settlement:

...Your Committee consider that it is essential to meet the just and reasonable wishes of Canada to be enabled to annex to her territory such portion of the land in her neighbourhood as may be available to her for the purpose of settlement, with which lands she is willing to open and maintain communications, and for which she will provide the means of local administration. Your Committee apprehend that the districts on the Red River and the Saskatchewan are among those likely to be desired for early occupation.

...Your Committee trusts that there will no difficulty in effecting arrangements as between Her Majesty's Government and the Hudson's

\footnotetext{
${ }^{43}$ Owram, 53.

${ }^{44}$ Ibid.

${ }^{45}$ Alexander Morris, Nova Britannia (Toronto, 1884), 29-30.
} 
Bay Company by which these districts may be ceded to Canada on equitable principles... ${ }^{46}$

Of course, there were difficulties a plenty, the most prevalent of these was the sheer ignorance about the area being opened for settlement. Therefore, actions were undertaken to rectify the situation, commencing one of the most intense periods of exploration British North America had seen.

\section{Imperialism's Handmaid: Geography}

While planting a flag in the ground and proclaiming a territory as being under the sovereignty of a particular nation was, metaphorically, a method of amassing land, physically acquiring these regions necessitated the undertaking of more practical actions. Accumulation for the sake of having more land under a country's jurisdiction certainly had potential benefits for adding to the nation's treasury and status among western European nations. However, turning potentialities into realities— to make these acquired lands useful and to counterbalance the less savory consequences of increased monies for bureaucracy and defence needed to maintain them-required a rational, systematic, and ultimately scientific approach to the land. In other words, there had to be a reason for expansion, for exploration, and for conquering certain areas of the world. Although a great deal of the world was explored during this time, not every piece was secured. Utility was the key to imperialist conceptions of the land, and indeed the primary impetus for expansionism, and utility could only be established through intense study of lands

\footnotetext{
${ }^{46}$ As quoted in Hill, 60.
} 
sought. In short, geography became the handmaiden of imperialism. Douglas W. Freshfield, president of the Royal Geographical Society in 1917, perhaps best summarized geography's key role in empire building when he said:

The attempt to build an empire or to develop its resources without geography is like building a house without first considering the climate or the locality, or seeing the character of the soil on which you must plant its foundations. ${ }^{47}$

Canada's Northwest was seen to fit neatly within this paradigm. With the break-up of the Hudson's Bay Company and the eventual transfer of their territories to Canada in 1870, Canada gained the means through which it could transform itself from dependent to aggressor, and possibly even an empire in its own right. But this was no easy task. As a fledgling nation seeking to assert itself in the Empire and beyond, Canada literally had to pull itself together. It was a country of loosely assembled, disparate pieces stitched together from cities, towns, and settlements constructed along the edges of the North American continent and St. Lawrence River, separated by a morass of rocks and marshes, the immense expanse of the Prairies, and the daunting peaks of the Rockies. In short, Canada was greatly challenged to present itself as a unified political entity. However, it was in this inherent vastness, this seeming hindrance, that Canada's potential was realized. As discussed in the previous chapter, Canada's destiny was seen to lie in her natural resources. Development of the Northwest was equated with the development of British institutions and morals across the whole of the country, and perhaps even beyond into Asia. The sheer breadth and the assumed potential resources available for

\footnotetext{
${ }^{47}$ As quoted in Morag Bell, Robin Butlin and Michael Heffernan's "Introduction," Geography and
} 
consumption presented the opportunity to facilitate colonial "civilizing" influences on a large scale, and theoretically making Canada a key player in the imperial project.

However, the path by which this was to be attained was based on the assumption of the Northwest's utility. What "factual" data there was about the Northwest was neither encouraging nor trustworthy, and compounded by the realization that residence in the Northwest-if not the country as a whole-was generally transitory in nature. As one writer humorously put it in 1826, "we have conducted ourselves in Canada...as if we had made up our minds to evacuate the country at no distant period." ${ }^{48}$ Thus, a comprehensive geographical re-analysis of the Northwest was critical to the fulfillment of Canada's self-perceived destiny. Old generalizations needed to be dispelled in order to justify the acquisition of the Hudson's Bay territories-although its seems as if they were trading one set of suppositions for another.

This acquisition of knowledge, in turn, represented another facet of the imperial project. Geography-etymologically constructed from geo for world and graphie for writing-has, until well into this century, been traditionally conceived as the science of the earth. It has also been perceived, erroneously, by many as a rather straightforward pursuit that simply involves studying and recording what lay before the observer. Granted, observation and description were the primary foundations for nineteenthcentury Geography, Morag Bell, Robin Butlin, and Michael Heffernan, in their book Geography and Imperialism, argue that physical geography, as part of modern European

\footnotetext{
Imperialism (Manchester, 1995), 1.

${ }^{48}$ J.C. Smyth, Reflections Upon the Value of the British West Indian Colonies and the British North American
} 
science, acted in tandem with the larger imperial goal to comprehend the contents of the world. Because geography attempted to re-constitute the world into "coherent, recordable, chunks of data" and then reassemble it in a medium they could understand (science), it worked with imperialism's quest "to know all, to understand all and, by implication, control all." ${ }^{\prime 49}$ Geography then, aided in territorial conquest. Conceptually re-fashioning new lands in the form of scientific investigation allowed imperialists to claim "authority over that region's soul and identity."10

Consider the geographer's primary tool: the map. Maps, acting to delineate geological forms and present spatial demarcations describing soil content and climate may initially seem fairly innocuous. Most people have at some point consulted a map to determine how to get from one place to another, or perhaps referred to an atlas to ascertain where certain species of trees or birds can be found. However, maps illustrate far more than just the shapes of continents and the paths of highways. Rather, they are highly constructed documents with deeply imbedded preconceptions about the land. Maps depict the jurisdictional boundaries of countries, delineating areas controlled by political powers, that divide continents into discrete units. Borders are not, for the most part, natural geological formations; they are arbitrary, intangible barriers erected by political forces. For example, the Canada/U.S. border along the 49th Parallel-itself an artificial, invisible line imposed upon the globe-is, geographically, a less than logical place for a political boundary. Nonetheless, it was negotiated in spite of geological forms, bisecting

Provinces (London, 1826), 27.

${ }^{49}$ Bell, Butlin and Heffernan, 3. 
the Great Lakes, dividing the Great Plains, and traversing uneasily through the Rockies. Further demonstrating the utter disregard for physical geography and the arbitrary nature of borders was that the tip of Vancouver Island was initially sliced off before further negotiations ceded the whole of the island to Canada. Borders may be influenced by geography, but political concerns ultimately determine where they lay.

Moreover, while some maps were fashioned in a more geographical vein, divisions decided by the nature of the land itself, these documents cannot be considered neutral catalogues of the world. Detailing where certain types of soil lay, what types of trees grow, which minerals can be found, and even what the climate is like, these maps are texts regarding the ways in which particular areas of the globe can be utilized for farming, logging, mining, and industrial, commercial, and residential development. Thus, maps are not simply representations of natural forms and facts about the land, they can show how it can be used. In other words, maps reflect the potential utility of the land (and water). Maps do not just inform, they instruct—and that is what gives them their power. ${ }^{51}$ Since a map is a reflection of the state of knowledge about a particular geographical region, ${ }^{52}$ the more precise the map, the more information it contains, the greater one's sense of control over the land becomes.

\section{Geography's Handmaid: Photography}

Pictorial representations had the ability to convey more than "factual" data of a region's

\footnotetext{
${ }^{50}$ Ibid.

${ }^{51}$ See Dennis Wood, The Power of Maps (New York, 1992).
} 
physical features, and could facilitate the extension of authority. The impulse to catalogue and document the land through maps, reports, and images acted as a mode of territorial conquest. These made the unfamiliar known by subjugating the land to external, culturally determined criteria. Indeed, sketches and maps were the only means previously available for the visual communication of information, as merely describing a place, formation, or landscape simply with words was seen as inadequate. European perceptions of the world were achieved through ideological prerequisites, such as order and unity, imposed upon the globe, and this view demanded a form of representation that was both objective and comprehensive in order to encompass it. ${ }^{53}$ The concurrent developments of photography, the rise of empiricism, and imperialistic conquest is no accident. Weston Naef and James Wood, in Era of Exploration, note that the rapid development of photography as a visual medium seems to coincide with a heightened interest in the land. ${ }^{54}$

From its advent, photography seemed the ideal tool for geographers, although its technical complexities made it quite difficult to use in the field, as will be discussed in the next chapter. Photography's apparent ability to transcribe reality directly seemed in accord with geographical imperatives to record the world accurately. ${ }^{55}$ Sir John F.W. Herschel, in his 1861 Physical Geography stated that pure descriptive geography should

\footnotetext{
${ }^{52}$ Javorski, 6.

53 James R. Ryan, "Imperial Landscapes: Photography, Geography and British Overseas Exploration, 18581872," Geography and Imperialism, Morag Bell et al., eds. (Manchester, 1995), 55-6.

${ }^{54}$ Weston Naef and James R. Wood, Era of Exploration (New York, 1975), 12.

${ }^{55}$ Ryan, 57.
} 
"exhibit a true and faithful picture, a sort of daguerreotype." ${ }^{56}$ Kenneth H. Craik in his article "Psychological Reflections on Landscape" has asserted that the perception of landscapes was affected by the medium of their presentation. ${ }^{57}$ Photography's illusion of accuracy and objectivity conferred upon photographs an authority and validity akin to scientific truths - a status that paintings and sketches could not achieve. ${ }^{58}$ Britain's Corps of Royal Engineers were long-time advocates of using photography as a scientific device to record the nature of a country. ${ }^{59}$ One Captain John Donnelly declared in an 1860 issue of The British Journal of Photography that "[p]hotographs of a country gave a most truthful and accurate idea of it. They would do more than to give an accurate idea of any particular position than yards of description on foolscap."60 Although photography's apparent "absolute material accuracy” is an obvious benefit to geographers' attempts to map the globe, because photography also shared geography's "twodimensional world view," it was also a means for geography to legitimize its "claim to reduce the world accurately to a uniform projection." ${ }^{61}$ Photography supported the belief that the globe could be broken down into recordable chunks of data and reassembled to make a whole-one of imperialism's modes of conquest. Moreover, the technical process of photography had a "particular symbolic significance" for imperialists. Since a photograph was formed through the exposure of a negative to sunlight, this light, in turn,

\footnotetext{
${ }^{56}$ As quoted in Ryan, 57.

${ }^{57}$ Kenneth H. Craik, "Psychological Reflections on Landscape," Landscape Meaning and Values. Edmund C. Penning-Roswell et al., eds. (London, 1986), 49.

${ }^{58}$ Ibid.

${ }^{59}$ Andrew J. Birrell, Into the Silent Land (Ottawa, 1975), no page number.

${ }^{60}$ John Donnelly, British Journal of Photography (15 June 1860). As quoted in Ryan, 57.

${ }^{61}$ Ryan, 57.
} 
was seen as an extension of Christian civilization and scientific knowledge. Photographs, then, became representations of the exposure of the "dark" recesses of the globe, making the "civilizing mission" of the imperialist project evident. ${ }^{62}$

Photography, then, also played a role in the appropriation of lands. Accumulation of knowledge facilitated comprehension, which in turn lead to a sense of control over a particular area since it had been intellectually mastered. However, to quote Susan Sontag: "To photograph is to appropriate the thing photographed." ${ }^{63}$ In the case of imperial expeditions, intense scrutiny dissected the land and determined aspects that would be of benefit to the Dominion, and by extension, the Empire. Photographed landscapes acted as a means of political appropriation. Photographs and their dissemination represented the land visually to represent imperialist concerns; documenting landscapes became a means of establishing an imperial presence and claiming control of the land. In this respect, the inclusion of staffage figures as markers of occupation became critical as they can be interpreted as a particularly effective method of implicitly claiming possession, particularly in spaces where colonizers were insecure. Landscape images became instruments of imperial cultural powers, for as conceptual structures, they also performed as cultural representations, revealing a great deal about the ideological landscapes of imperialism.

\footnotetext{
${ }^{62}$ James Ryan, Picturing Empire (Chicago, 1997), 30.

${ }^{63}$ Susan Sontag, On Photography (New York, 1977), 4.
} 
Benjamin Baltzly's photograph Forest Scene on North Thompson River, 165 Miles Above Kamloops, BC (fig. 14) of September 20, 1871 illustrates this point. ${ }^{64}$ In this work, the viewer is presented with an apparent "forest wall" of twisting tree trunks in close proximity to each other, a deep forest floor, and only bits of sky peeking through the branches. On one level, it can be interpreted as a demonstration of how disorderly, even threatening, nature was in the Northwest. Vegetation is abundant but it is undisciplined—and very much unlike the forests of Europe. Thick, tangled underbrush impeded human progression through the region, and the trees grew so closely together that they obstructed the sky. In short, this work could be viewed as the epitome of what a nineteenth-century viewer would perceive to be an "uncivilized" primeval forest. Baltzly in his journal, which was published in the Montreal Gazette during 1872, declared that he took this photograph to show how difficult travel was due to the density of the forest. His description simultaneously reveals how isolated and distanced from the world he felt in the forest, however picturesque it may be.

When in these forests, I at times compare myself to a merman, who while at the bottom of the ocean, amid a large growth of queer sea-weed, and surrounded by beautiful shells and the treasurer of a thousand wrecks, should look up from his abo[d]e of peace, and see the surface of the water $\mathrm{f}[\mathrm{a}] \mathrm{r}$ above him, raging in a terrific storm. ${ }^{65}$

However, we must consider that this photograph was taken while Baltzly was on the 1871 Geological Survey of Canada—an expedition with the sole purpose of identifying and cataloguing the physical and material features of the interior of the new Dominion.

\footnotetext{
${ }^{64}$ The following interpretation owes much to James Ryan's interpretation of John Kirk's Lupata July 13th 1859 in Ryan's essay "Imperial Landscapes," 61.
} 
In other words, their mission was to discover and report on all those aspects which could be economically exploited and reinforce the strength of Canada's political union. In this respect, Forest Trees can be interpreted as a colonial prospect; that is, the future utility of the landscape was captured as much as its present state of "wilderness." The thick forests, once viewed as obstacles, can be seen as being presented as unruly fertility and portents to riches that could be made from their harvest. Further, the perceived barbarity of the region, as well as the absence of industry and labour, could be equated with space awaiting the introduction of "civilizing" institutions. Photographs like this example, therefore, not only documented the land in order to provide a record of its topography, but it also served to suggest the land's future conformation to imperialist ideology. It was in effect the Northwest's potential, more than its present reality, being photographed.

\section{Penetrating the Interior At Last-With Camera in Hand}

As discussed earlier, by the mid-nineteenth century, there had been a change in sentiment regarding the Northwest. Instead of an obstacle, it was now considered a valuable commodity for the future development of the Empire. The 1850s then witnessed a series of expeditions into the Northwest with this new objective in mind. If Canada was to acquire what was previously under the Hudson Bay Company's domain, officials wanted a clear impression of the area's physical geography and agricultural potential. Surveys were not conducted merely to map the land and determine its physical characteristics; their primary functions were to discover areas that would best support

\footnotetext{
${ }^{65}$ Baltzly in the Gazette, 8 July 1872.
} 
settlement - where the best land for farming was located, and how much of it was there, or regions where resources could be hewn or mined. Indeed, these latter concerns were almost as important as the former. For settlement to proceed, it had to be determined whether there were the adequate resources to support a large-scale agricultural project. Further, some survey parties were instructed to find routes for trade and travel via the proposed transcontinental railroad. This internal exploration was very much in keeping with larger expeditionary trends seen in other imperial powers, and many of the same attitudes were evident, as illustrated in the previous chapter. Despite a dearth of firsthand knowledge and an overall lack of European and Euro-Canadian presence, imperialist assumptions of ownership were quite evident, thereby implying that the land's resources were available for consumption, were in need of a "civilizing" influence to transform its perceived "emptiness" into a productive space:

There are vast areas... which lie only waiting for the presence of civilized man and the appliances of civilisation, to deal with their boundless resources and transform into happy homes and prosperous spheres of activity. ${ }^{66}$

Furthermore descriptions of the land are typically written in terms of its usefulness to Britain or Canada rather than as pure record of geographical data. For example, The British Association's Handbook of 1884 declared that:

...the North-West from the valley of the Red River to the Rocky Mountains has no features. It is one vast illimitable plain endowed with a monotony of fertility.... The North-West is above all else an inexhaustible wheat mine. ${ }^{67}$

${ }^{66}$ George R. Parkin, "The Geographical Unity of the British Empire," The Scottish Geographical Magazine (1894), 225.

${ }^{67}$ As quoted in Trevor H. Levere's "The British Association Goes West: Montreal 1884," Transactions of the Royal Society of Canada 4th ser. Vol.20 (1982): 494. 
Thus, even at this late date, after numerous expeditions into the Northwest, old landscape descriptions about the land persisted. However, there is a decided change in landscape meaning. Previously, this large "featureless" plain would have been equated with sterility; now it is seen as synonymous with fecundity.

Pictorial representations of these newly "discovered" areas were of particular importance, a symptom of both the broad cultural demand for visual information, evidenced by the proliferation of pictorial papers, such as The Illustrated London News, as well as the need to have a supposedly accurate accounting of the Northwest. The camera, from the late 1850s onwards, began to be used to fulfill this demand, usurping the work of topographic artists - if not replacing them entirely. Edouard Deville, Surveyor General of Canada, declared in 1884 "that no report of an expedition is considered complete unless accompanied by photographs." ${ }^{68}$ As has been discussed, many were captivated by its apparent ability to record physical reality precisely, objectively, and with incredible detail. Its seeming truthfulness was particularly compelling, as it was believed that the camera transcended the subjective vision of the artist. Viewed merely as a mechanical process, photographs were considered to be dispassionate, their veracity assured by the mathematization of space. What better tool could there be to garner accurate impressions of this relatively unknown land? As Andrew J. Birrell examined in his exhibition catalogue, Into the Silent Land, as photography became more "practical"that is, easier to execute in the field-topographic artists began to be replaced by

\footnotetext{
${ }^{68}$ As quoted in Andrew J. Birrell's "The North American Boundary Commission," History of Photography,
} 
photographers on government sponsored surveys and explorations. ${ }^{69}$ Although many of the presuppositions Victorians had regarding photography have since been disproved, the images captured by these photographers remain invaluable as a record of Canada's Northwest just prior to European settlement, “...form[ing] a bridge between our time and a Canada about to be transformed by the hand of the white man." 70

The first expedition in Canada to use photography was the 1858 Assiniboine and Saskatchewan Exploring Expedition led by Henry Youle Hind. It can be viewed as the "Canadian counterpart" of the British expedition party sent out the preceding year, headed by geologist and botanist Captain John Palliser. While credited with mapping Canada's Northwest, Palliser also made extensive notes regarding which areas would be ideal for agricultural settlement; he also established an emigration route between Lake Superior and the Red River Settlement, Manitoba. Hind's expedition greatly expanded the scope of Palliser's mission and determined that the "Fertile Belt" (fig. 13) which Palliser had mapped was more extensive than originally estimated. With the Canadian government expressing interest in acquiring the lands then held by the Hudson's Bay Company, the Canadian government commissioned an exploratory expedition in order

20.2 (Summer 1996): 113.

${ }^{69}$ Andrew J. Birrell, Into the Silent Land (Ottawa, 1975), no page number.

${ }^{70}$ Ibid., no page number.

${ }^{71}$ The Fertile Belt was a geographical entity believed to stretch across the whole of the Northwest "in a giant arc from the American border at Red River northwest to the forks of the Saskatchewan and from there along the North Saskatchewan to the Rocky Mountains. As it approached the foothills of the Rockies it turned southward until it reached the border at 114 degrees west." Owram, 68. 
to determine more accurately the geology, topography, and agricultural potential of the Northwest. $^{72}$

This expedition is of particular interest to the present study as it was, again, the first to employ a photographer, namely Humphrey Lloyd Hime, as part of its programme of establishing evidence. But recording visual information was not left entirely to him; the artist John Fleming was also included on the journey. Nor was Hime's primary function photography; he was an accomplished draughtsman, and his photographing duties were only to be undertaken after his other work was finished. ${ }^{73}$ Nonetheless, it is not known precisely why Hind requested a photographer for this expedition, although Birrell writes that Hind "did mention the advantage of a negative from which any number to prints could be taken to illustrate a report." ${ }^{74}$ Hime's instructions were to take photographs of "all objects of interest susceptible of photographic delineation." ${ }^{75}$ Broad parameters indeed. Although Hime created images for an official report read by politicians, these same photographs functioned concurrently as publicity images. In fact, Hind had made arrangements with The Illustrated London News to have photographs of natives, scenery, and HBC forts reproduced for its pages. Nevertheless, documenting these discoveries using photography proved quite difficult. Hime took only eight photographs between June 14 and September 4; wet weather and hordes of locusts made picture-taking virtually impossible:

\footnotetext{
${ }^{72}$ Richard J. Huyda, Camera in the Interior: 1858 (Toronto, 1975), 5.

${ }^{73}$ Ibid., 7-8.

${ }^{74}$ Ibid., 8.

${ }^{75}$ Ibid., 7-8..
} 
Everywhere we find grasshoppers...innumerable hosts of grasshoppers were flying northward in the direction of the wind. At times they would cast a shadow over the prairie, and for several hours one day, the sky from the horizon, to an altitude of thirty degrees, acquired an indescribably brilliant and white tint, and seemed fairly luminous as the semitransparent wings of countless millions of grasshoppers... relfected the light of the sun. ${ }^{76}$

Furthermore, the resulting images from this part of the expedition were "soft"- the details indistinct-and many of the negatives show a marked degree of deterioration. Official photographs from this expedition were declared a failure.

The next recorded expedition was the North American Boundary Commission of 1858-1862. Led by the Corps of Royal Engineers, and headed by Lieutenant-Colonel John Hawkins, this expedition was less about discovery and more about the preservation of British territory. With the discovery of gold at Yale and Emory Bar on the Thompson River-in what became British Columbia-James Douglas, Governor of Vancouver Island, urgently requested that the boundary between American and British territory be officially marked. Ostensibly, this was meant to prevent disorder and confusion among citizens, but in fact, it was probably meant to establish firmly where British law prevailed and to prevent the United States from claiming the area for themselves. Although the Oregon Treaty of 1846 had determined that the border was to fall on the 49th Parallel, it had not been formally marked. ${ }^{77}$ Past experience had shown Britain that such boundaries did not always impede American ambitions. Thousands of prospectors were pouring into the area, the majority of which were from Washington and California, and worries over

\footnotetext{
${ }^{76}$ Henry Youle Hind, as quoted in Huyda, 14.

${ }^{77}$ Andrew J. Birrell, "Survey Photography in British Columbia, 1858-1900," BC Studies 52 (Winter 1981-
} 
another jurisdictional dispute and possible conflict led British and American governments to establish a Joint Boundary Commission in 1857 in order to prevent such an occurrence. ${ }^{78}$ This Commission was supposed to survey not only the border through the Rockies, but also across the Prairies to the North-West Angle of Lake of the Woods. However, slow progress through the mountains and the outbreak of the Civil War in the U.S. stopped work on the east side of the Rockies. ${ }^{79}$

Photographers were included by both parts of the Commission, although no specific reason was given for their inclusion on this mission. Considering that their objective was to mark precisely the border and to gather scientific information, the proposed use of photography is perhaps not a surprise. ${ }^{80}$ Indeed, the Royal Engineers had first shown an interest in photography during the Crimean War, primarily for its possible military application, and by 1858, photography had become part of the curriculum at the Royal Engineer Establishment in Chatham, England. "Sappers" were to receive photographic instruction so that they may "send home periodical photographs of all works in progress, and to photograph...all objects, either valuable in a professional point of view, or illustrative of History, Ethnology, Natural History, Antiquities, \&c." ${ }^{81}$ This statement seems to confirm James Ryan's assertion that "the practice of photography was defined and controlled in relation to the aims of the expedition." ${ }_{82}$ Photography was proposed to be used not only to document the marking of the border, but to validate its strength as

82): 41 .

${ }^{78}$ Brock Silversides, Waiting for the Light (Saskatoon, 1995), 16. Birrell, "Survey Photography," 41.

${ }^{79}$ Birrell, "The North American Boundary Commission," 114.

${ }^{80}$ Ibid., 113.

${ }^{81}$ As quoted in Birrell, "Survey Photography," 40. 
an international boundary. Photographing unusual or unique land forms on or near the border, such as La Roche Percée (seen in fig. 8), provided reference points that seemed to prove an area's political domination accurately. Royal Engineer Captain Henry Schaw, writing in 1860 , envisioned such a application for photography in the military:

In surveying boundaries of different countries, photographs of remarkable natural features of the country, which may either occur in the boundary line or visible from certain points in it will tend to fix the positions of the line with great certainty. ${ }^{83}$

Photographically documenting the border provided another means of enforcing it.

Retaining a photographer for the North American Boundary Commission was a bit problematical though. The first photographer sent to B.C. deserted soon after the detachment arrived in Esquimalt during the summer of 1858, and it was not until a year later that his two replacements arrived. Unfortunately, because this survey remained unfinished, it was resumed between 1872-74. An unofficial survey by an American Army officer, General George Sykes, suggested that the position of the border at Pembina was faulty. Sykes' "correction" placed the border so far north that the HBC post at Pembina appeared to be in American territory. ${ }^{84}$ To avoid potential conflicts, again, another Joint Boundary Commission was established in 1872 by the two governments with the express goal of marking the entire border from the Northwest Angle of Lake of the Woods to the Rocky Mountains. By the time of this "re-survey," the Corps of Royal Engineers had dispensed with official artists and entirely replaced them with

\footnotetext{
${ }^{82}$ Ryan, "Imperial Landscapes," 57.

${ }^{83}$ Henry Schaw, Paper XVIII in the Professional Papers of the Corps of Royal Engineers (1860). As quoted in Birrell, "North American Boundary Commission," 113.

${ }^{84}$ Ibid., 114.
} 
photographers, perhaps marking the acceptance of a new type of documentary tool. The photographers sent out on this mission were highly trained individuals, and their aptitude for the medium is quite evident - these were not amateurs or surveyors making use of a device-even though their work was to be confined to points of scientific interest.

As on the Assiniboine and Saskatchewan mission, conditions were far from conducive for photography, considering both the rugged terrain and the amount of heavy, bulky camera equipment to be hauled over it. As mentioned previously, British Columbia's forests were virtually impenetrable, and paths had to be created before any movement of the party could progress, much less take a picture. Further, swarms of mosquitoes and sandflies made work (and life) nearly unbearable. Charles Wilson, Secretary of the 1858 Boundary Commission, writes how the mosquitoes were so bad that it was perfect agony performing even the regular actions of life. ...[T]hey settle en masse upon you perfectly covering every portion of the body exposed. We sit wrapped up in leather with gloves on and bags around our head and even that cannot keep them off; none of us have had any sleep for the last two nights and we can scarcely eat, exposing the face is such a painful operation, day and night no peace, in fact were are utterly miserable.... ${ }^{85}$

Under these circumstances, it is remarkable that any photographs were taken, regardless of quality. Hawkins, however, was disappointed in the results produced on the first Boundary Commission, citing that the equipment had proven too cumbersome to justify the added burden. He felt that similar results could be achieved by an officer who was a

${ }^{85}$ Charles Wilson, Mapping the Frontier, George F.G. Stanley, ed. (Toronto, 1970), 58. 
good artist. ${ }^{86}$ In spite of these difficulties and "failures," governments were not deterred from using cameras in similar situations, perhaps proving that photography was indeed becoming more a part of exploring and surveying missions. In fact, Captain Donald Roderick Cameron, leader of the second North American Boundary Commission expedition, made no reference to difficulties encountered with using the camera. Cameron actually insisted that a photographer be included; to him, photography was a necessary aspect of the Boundary Commission, so long as the photographs were "confined to points of interest or such as may be usefully illustrative of the progress of the Commission." ${ }^{87}$

In 1871, British Columbia joined the new Dominion of Canada, but only on the condition that a transcontinental railway would be constructed to link British Columbia with Eastern Canada. Accordingly, Sir John A. Macdonald appointed Sandford Fleming as Chief Engineer of the Canadian Pacific Railway (CPR); Fleming took immediate action, forming ten survey parties to determine the best route across Canada. These surveys were in operation until 1879. Specific attention was paid to British Columbia's interior, where mountains, thick forests, and swamps posed the greatest obstacles to be overcome. It also remained a largely unknown region, so Fleming, "[f]rom our want of knowledge of the country," ${ }^{\prime 8}$ decided to hire photographer Charles Horetzky to document their discoveries. Specifically, Horetzky was to photograph "objects of interest,

\footnotetext{
${ }^{86} \mathrm{Ibid}$.

${ }^{87}$ Birrell, "North American Boundary Commission," 114.

${ }^{88}$ Birrell, "Survey Photography," 49.
} 
illustrative of the physical features of the county...." ${ }_{89}$ Again, this motive serves to emphasize how photography was used to reveal the character of the landscape, thus enabling viewers of the photographs to control it.

Concurrent with the CPR surveys, in 1871, at the recommendation of Joseph Truetch, the Geological Survey of Canada (GSC) undertook a companion survey of the British Columbia interior. This survey was geared more towards revealing the geological character of this region than trying to get around it. Alfred Selwyn, Director of the GSC, made arrangements for a small party to penetrate the interior. Although it is unknown who suggested the inclusion of a photographer, Joseph Howe, Secretary for the Provinces, authorized Selwyn to acquire the services of a professional photographer for the expedition. This demonstrated the degree to which photographs-high quality photographs taken by a non-military professional—were desired. Benjamin Baltzly, from the firm of William Notman, was hired in this capacity, charged with "...secur[ing] accurate illustrations of the physical features of the country and of other objects of interest which may be met with...." ${ }^{90}$ As with the Boundary Commissions, the terrain proved to be a challenge for the equipment, but Selwyn greatly admired the photographs taken—although he abhorred the cost of obtaining them.

But the commercial benefits of these works could not be denied. Although included in the official reports, Notman retained the negatives and made many prints for public consumption. Even Selwyn was aware of the demand for these photographs, despite the

\footnotetext{
${ }^{89}$ Sandford Fleming, as quoted in Birrell, "Survey Photography," 53.

${ }^{90}$ Alfred Selwyn, as quoted in Birrell, Benjamin Baltzly, 11.
} 
cost. By the mid-1880s, the camera was an accepted and integral part of the GSC's field work, and the quality of the photographs taken was admired in many circles. They were used regularly in international exhibitions, and the GSC received weekly requests for prints from amateur and professional scientists. The Canadian Pacific Railway even proposed to use a large number of GSC views of the prairies to encourage immigration.

\section{Imperial Landscapes: Staffage in Photographs of the West}

Therefore, if the purpose of these expeditions was to dissect the interior and lay bare its potentialities as well as its deficiencies, and since the Northwest largely remained terra incognita to the majority of Canadians, the use of staffage in these photographs was particularly significant. For centuries, there had been the perception that the Northwest was empty, barren, and ultimately unsuitable for human-that is, Euro-Canadianhabitation. In some ways, this belief had some validity. Geographically and conceptually, the Northwest was isolated from eastern Canada. Lack of interest had curtailed a full appreciation for the character of the land, inhibiting any sense or desire that this region could possibly be possessed and controlled by Eastern Canadians. Therefore, there was an acute need for expansionists not only to document the land, but make it known as AngloCanadian. Staffage, as discussed in the previous chapter, aided in establishing a legal and conceptual sense of ownership of the Northwest. Here, I endeavour to illustrate how staffage assisted in making this sense of possession more concrete and familiar to contemporary viewers. 
One way photographers sought to make the unknown known was to use staffage to provide a sense of scale. The physical features of the Northwest were essentially foreign to Eastern Canadians and British officials, and the insertion of a human form helped put a landscape into perspective for viewers, making it comprehensible to them. Consider again, Baltzly's photograph Forest Trees on the North Thompson River (fig. 15) and compare it to his Camping on the Thompson River (fig. 16) from the same expedition. The former photograph, for all its wondrous imperial connotations, does not give as clear an idea of the scale of the forests faced by party members as the latter photograph does. Camping by contrast, gives a better idea of the nature of British Columbia's forests. The lone figure in front of his tent, with the entire camp strewn amongst the underbrush like laundry hanging to dry, provides a human referent that a viewer can use to gauge the scale of the landscape more or less accurately. Even though this figure is sitting down, a clearer sense for the height and breadth of the trees as well as for the unrelenting pervasiveness of the undergrowth is achieved. Moreover, using staffage to provide scale also demonstrates the dimensions of the obstacles that had to be overcome so as to fulfill dreams of civilization and prosperity.

Indeed, in expedition photographs, using staffage to illustrate scale was generally seen as its primary function, reducing the role of staffage to that of documentary aid. However, as I argue throughout this thesis, staffage also actively functioned in constructing exploratory photographs as ideologically invested images. Although staffage helped to explain a foreign landscape to European and Euro-Canadian viewers, this was hardly a scientific means of doing so. There were other methods available to document 
scale and size, principally through measurements and calculations. Why then present minuscule figures among massive forms?

As James R. Ryan has argued, photography was defined and practiced in relation to the aims of the expedition; ${ }^{91}$ staffage was not excluded from these mandates. Explorations of the Northwest were undertaken more or less to take inventory of the region's resources and to establish where obstacles were located so they could be surmounted. Expeditionary photography, then, was used as a means of producing geographical evidence and proving the validity of colonial vision. Staffage furthered expansionists' claims and emphasized the breadth of land available for consumption. In other words, staffage's literal interpretation as small figures which provide a sense of scale actually served to further the imperial project by visually demonstrating, explicitly, the sheer magnitude of land and resources in the Northwest to be explored, settled, and exploited.

Examine the photograph Souris River (fig. 19) of 1873 by an unknown photographer from the Corps of Royal Engineers on the North American Boundary Commission. The river curves gently through the fore- and middle ground, and leads the eye back into deep expanse of land extending to rolling hills in the background. Thick vegetation, shrubs, and trees line the waterway—seemingly dispelling the myth that the Prairies were an arid wasteland. At first glance, the tiny figure in the river is scarcely noticeable, yet there he is: head bent, focused on whatever activity he's engaged in. The immensity of the area is made clearly evident by his minuscule size. He not only makes the dimensions 
of the land comprehensible, he also emphasizes how ample those proportions were. Moreover, his presence acts as a witness to one of the greatest concerns about settlement of the Northwest: the availability of water. The feasibility of settlement is therefore implied, and the presence of staffage prefigures the advance of human habitation. Also, given the utter vastness of land, lumber, minerals, and other resources potentially available, this photograph also fosters the perception that they were unlimited. It, therefore, underscores the economic impetus for expansion.

In this case, as in others, staffage acted as mediator between the object photographed and the viewer of it. The figures role as witnesses and representatives of European and Euro-Canadian society were made more potent by the nature of the surveys they undertook. Because they were sponsored by the government, explorers were essentially extensions of the political powers located in Ottawa and Britain. The use of staffage then, could be considered a means of inserting these bureaucratic forces into the landscape, linking officialdom to the Northwest. Not only does this proclaim that these areas are under control, it also proved they were subject to their political authority.

It should also be pointed out that although imperialists and nineteenth-century society as a whole generally proclaimed photography as being incapable of falling prey to human prejudices that could distort the transmission of truth, Souris River proves how false this belief was. While an impression of a vast expanse of land is implied through the depth of the photograph, the viewer doesn't really get to see it. In the middle ground, a swath of trees appear at the right, and the photographer has placed his camera so that

${ }^{91}$ Ryan, "Imperial Landscapes," 57. 
tops of the vegetation obscure the horizon line, effectively excluding much of the view of the grassy plains behind. This facilitates the impression, as noted above, that the Prairies were not arid and sterile but instead were lush and fertile and treed-the wide-open expanses generally associated with the Prairies have been deliberately concealed so as to show a prospect more in keeping with expectations for settlement.

Lastly, colonial photography has often been explained as a tool of naturalization, and I would argue that staffage participates very directly in that process. Photographs were often constructed to reassure Victorian audiences familiarity because they seemed to present images that would reproduce how they themselves would see the object, person, or place had they actually been there. First-hand knowledge was a fundamental precept of science and Positivism. Visual knowledge of an object was a vital step in the intellectual conquest of the natural world: to see was to know and understand, and ultimately control. As such, generally, through a photograph's apparent realism, the unfamiliar was rendered familiar, the unknown known. The photographic subject was effectively neutralized, like an insect pinned to a board; it has been laid out for study, immobilized, and unable to defend itself against its examiner. Feelings of comfort were further enhanced by the temporal and spatial distance from the object photographed.

Staffage-in particular, white, European figures_-aided in making a photograph seem familiar. As mentioned previously, human figures made a scene more comprehensible to viewers; but figures of the same cultural background provided a human referent that they could identify with and ultimately project themselves on, further negating the alienness of the photograph. In other words, staffage domesticates the scene. If these figures, 
representatives of European culture, have penetrated the land, their presence implies that the area has been "tamed" and brought under the control of a civilizing influence. Often, the composure of figures in the landscapes belies any perceived threat there may be in being several hundred miles from home in possibly hostile country. Granted, scientists and military personnel would hardly wish to be recorded panicking, but in some images, the degree of comfort exhibited is unusual.

For example, Hime's Fort Ellice: Beaver Creek (fig. 18) of 1858, one of his few peopled landscapes done in the field, shows a figure in the foreground, apparently "caught" in the act of rearranging his pack. Given the nature of the wet-plate method, there is a sort of studied casualness in his pose, but overall he seems quite at ease, with one sleeve rolled up and the other dangling down. Another later work by William Hanson Boorne, a photographer based in Calgary who took views along the Canadian Pacific Railway, entitled The Hoodoos, Natural Monuments, Banff, (fig. 19) possibly from 1885-89, contains a single figure leaning against a large, unusually shaped rock with a insouciant stance, as if this were a lamppost in downtown Toronto instead of a geological formation that dwarfs him. While this "propping" can be explained away as a need to remain steady during the exposure of the photographic plate, this does not altogether account for the relative blasé attitude of some staffage figures. These figures are not awed or intimidated by their surroundings and rather seem to go calmly about their business, as they seem to do in La Roche Percée (fig. 8). In other words, they seem quite comfortable in the landscape, and this in turn aids in domesticating the foreign landscape. 
Another method that facilitated this effect of "taming the strange" was the application of Western aesthetic modes of representation in exploratory photography. Derrick Price and Liz Wells argue that since photography already seemed familiar to Victorian audiences, the "articulation of familiar-looking objects through established aesthetic conventions further feul[ed] realist notions associated with photography," consequently enhancing its "aura of authenticity." ${ }^{12}$ Subjecting landscapes to anthropocentric ideologies, such as "picturesque," "sublime," and "beautiful," also acted as a means of appropriation. ${ }^{93}$ In other words, because photographs complied with artistic preconceptions, they not only looked more "real" to audiences, this also served to extend their sense of control over the land. For example, Charles Horetzky's photograph From West Shore of Lake Tatla Looking Across Towards Mountain Range Between Tatla and Ominica, BC (fig. 20) of 1879 from the Canadian Pacific Railway Survey of that year seems to have more in common with a Caspar David Freidrich painting than a topographical document. Although there no people shown, humanity's presence is implied by the lone, empty boat seen on the shore in the foreground, and its juxtaposition against the moody, atmospheric landscape behind creates a greater sense of solitude and melancholy than an impression of the area's physical reality. Even Souris River demonstrates an aesthetic feeling towards the land in addition to its topographical forms. Its composition is similar to that of a landscape painting. The artistic convention or "golden rule" of landscape proportions for two-thirds land and one-third sky has

\footnotetext{
92 Price and Wells, 25.

${ }^{93}$ Victor Burgin, "Photographic Practice and Art Theory," Thinking Photography Victor Burgin, ed.
} 
apparently been observed, and the curving line of the river serves to lead the eye back through the photograph, much like the picturesque's "line of beauty." Also, the lighter patch of river in the middle ground breaks up the uniformity of the land masses, reflecting the sky and thus pulling the photograph together compositionally. ${ }^{94}$

\section{In Summary...}

Therefore, during the late 1850 s, the Northwest underwent a conceptual re-visualization that transformed it from barren hinterland to "wild luxuriance" where only colonial guidance was needed to convert its "now useless vegetation into all the requirements of civilized existence." 95 The Northwest was conceived as a vast field of resources "silently awaiting"96 the occupation of Europeans and Euro-Canadians; only then could it be considered a valuable asset to the Dominion and, by implication, the Empire. In other words, this wilderness was there to be utilized: ${ }^{97}$ to be farmed, mined, and hewn to provide raw materials for industrial interests in Eastern Canada and Europe. Surveys of the Northwest, in addition to documenting the topographical features of the region, in turn acted to record the imposition of this "new psychological order," 98 illustrating the assumed potential of the land more than its actual state.

(Houdmills, 1982), 47.

${ }^{94}$ For an opposing point of view, see Rosalind Krauss' "Photography Discursive Spaces" in Originality of the Avant Garde and Other Myths (Cambridge, Mass., 1983). She argues that since the intent of these photographs was scientific in origin, this naturally precludes any investigation into their aesthetic character.

${ }^{95}$ William Francis Butler, The Great Lone Land (London, 1872), 385.

${ }^{96}$ Ibid.

${ }^{97}$ William H. Truettner, "Ideology and Image: Justifying Westward Expansion," The West as America (Washington, 1991), 31.

${ }^{98}$ Ibid. 
Staffage, as I have argued, participated very directly in this transformative process. The presence of European and Euro-Canadian figures in the landscape could simultaneously represent the Northwest's capacity to support settlement by serving as a device to provide scale, as well as witnesses to the prospect of the country. Staffage figures, due to their small proportions, made the landscape seem that much grander, and thus seemed to demonstrate the vast amount of resources potentially available for harvest. Landscapes were further appropriated by the application of aesthetics that removed them from the natural, and made them objects to consume. As a representative of a colonial society, staffage figures not only foreshadowed the future "civilization" of the land, they also served to show its increased level of domesticity. Documenting European and Euro-Canadian occupancy in the landscape reinforced the notion that the Northwest was under the control of the Dominion, as well as strengthening the bond between Eastern and Western Canada. 


\section{Photography in the Field: Technical Consequences and Photographic Authority}

Although the phrase "photography in the field" has been used, until this point, in a specific manner, the difficulty of nineteenth-century photography needs to be clarified if the presence of staffage in photographs is to be fully understood. Photography during this time was highly complex and labour-intensive, making field-work incredibly difficult-as well as physically arduous. The large numbers of images produced under extreme circumstances is a remarkable achievement and a testament to individual doggedness. However, despite overcoming technical complexities, that photographers were included at all on expeditionary missions had a far more significant implication. As discussed previously, the increasing reliance on photographs as documents speaks to their perceived power as an impartial purveyor of facts; the conventional mediums of sketching and painting were no longer seen as entirely adequate techniques for transferring visual information for official purposes. Thus, this chapter will elucidate the methods, procedures, and problems of nineteenth-century photography, and explain why these images were given such authority. To this, the concept of the documentary and the manner in which photographs made it into the public sphere will also be examined. Given the intricacy of the photographic process, the repercussions of having staffage figures in expedition photographs become particularly meaningful. 


\section{The Camera Abroad}

If staffage can contribute to the ideological encoding of an image, as has been argued, the manner in which people come to appear in photographs is of some consequence. Initially, the answer to this may seem painfully obvious, but simply stating that people stand in front of the lens to be recorded in a landscape does not account for the complex nature of early nineteenth-century photography. Wet-plate photography, the photographic process used on the majority of the expeditions considered here, was a particularly intricate and cumbersome procedure made even more so when done in the field. However, determining a photograph's value by how difficult it was to produce technologically exposes this approach to certain pitfalls. Scholarship for the first hundred years after photography's birth often focused almost exclusively on its mechanical character, reducing the history of photography to a chronological progression of technical developments. Not only did this diminish the achievements of individual photographers, it also suppressed the importance of subject matter-if it was considered at all. How a work was created was given greater consideration than what kinds of images were made. ${ }^{1}$ Nonetheless, for the purposes of discussion here, an examination of the technical nature of photography is essential. Not only does it partially convey the importance of staffage in expedition photographs, it also demonstrates the significance of using photography in the field.

\footnotetext{
${ }^{1}$ Derrick Price and Liz Wells, "Thinking About Photography," Photography: A Critical Introduction, Liz Wells, ed. (London, 1997), 13.
} 
For several decades after its development, the first widely-used type of photography, called daguerreotypy, was a complex and unwieldy process. It was a technique fraught with many, many steps, and this intricacy was exacerbated by the fact that the entire process—sensitizing the plate, exposing it in a camera, then developing it - had to be done on site. ${ }^{2}$ For a photographer to produce a landscape photograph, all of the necessary equipment-weighing approximately fifty kilograms-had to be transported to the desired site. Exposure times were also quite demanding. Eight to ten minutes was the usual length of time needed for an image to be formed, although durations of thirty minutes were not unheard of. Technical advances in lenses and plate sensitivity reduced exposures to between thirty seconds and two minutes, but the basic process remained the same. A single image, therefore, required the use of large amounts of equipment and a great deal of time. Landscape daguerreotypes are rare in Canada, and peopled ones, such as Platt D. Babbitt's Group at Prospect Point, Niagara Falls of 1853 (fig. 21) showing two ladies and a gentleman taking in the spectacle of the great falls, are even scarcer.

It comes as no surprise that there is no record of daguerreotypes being used on any Canadian exploratory expedition. Although the end result was a highly detailed image admired by scientists and travel enthusiasts alike, the demands of the process curtailed

\footnotetext{
${ }^{2}$ A copper plate coated with a thin layer of silver was "exposed in an iodizing box to vapourized iodine which deposited itself on the plate, forming a light-sensitive silver iodine. It was then exposed in a camera for up to half an hour, depending on the brightness of the light and the aperture of the lens. The exposed plate was placed in a fuming box over a dish of mercury which was then vapourized. The vapour rose, came in contact with the exposed plate, and deposited itself in tiny globules in exact proportion to the amount of exposure each part of the plate had received. The positive image so formed was fixed by immersion in hyposulphite of soda. The result was a highly reflective image with incredible detail and tonal range." Andrew J. Birrell, "The Early Years: 1853-1885," Private Realms of Light, Lilly Koltun, ed. (Markham, 1984), 5.
} 
extensive outdoor use. Vagaries of sun, wind, and rain could also compromise the condition of the resulting image. The addition of figures was simply another factor that could possibly detract from the quality of the final image. To retain clarity and focus, people would have to remain completely still, which was extremely difficult to do given the length of time needed to expose the plate.

More than inconvenience precluded the use of daguerreotypy on Canadian expeditions. The process may have produced a richly detailed image, but the emphasis here is on the singular: daguerreotypy yielded a single, unique image. The finished plate was the completed photographic print; there was no negative from which multiple copies could be made. In other words, there would be no way to defray the costs incurred from equipment, supplies, personnel, and time used. Granted, woodcuts and engravings could —and were-generated from daguerreotypes, but they lacked both the degree of detail and "objectiveness" believed to be inherent to the original photographs. Reproductions could be made by re-photographing the original, but this avenue was not utilized frequently. Lastly, the inherent fragility of the daguerreotype ultimately limited its circulation. The final image simply "floated" on the silver-plated surface of a copper sheet: if the plate was not handled carefully, the image could be brushed off. ${ }^{3}$ Therefore, to protect them, each plate was mounted behind a piece of glass in a specially constructed case which made viewing them quite awkward. ${ }^{4}$

\footnotetext{
${ }^{3}$ Eugene Ostroff, Western Views and Eastern Visions (Washington, 1981), 10.

${ }^{4}$ Ibid.
} 
The development of the collodion or wet-plate photographic process by British amateur Frederick Scott Archer in 1851 made open-air photography more feasible, but not due to any simplification in the procedure itself. ${ }^{5}$ Outdoor work using wet-plate photography remained as complex as daguerreotypy, as well as possessing its own unique difficulties. Collodion, it was discovered, was found to be more sensitive when slightly damp than when it had dried, thereby significantly reducing exposure times to approximately between thirty seconds to five minutes. The consequences of this advantage were not negligible. Obviously, if the emulsion is the most sensitive when wet, this meant that individual plates had to be prepared just prior to exposure. Further, since the latent image on the plate would disappear if the collodion was allowed to harden, the plate had to be developed immediately after exposure. Thus, wet-plate photography required photographers to bring to the field all the necessary chemicals, glass plates, lenses, cameras, and water (as well as a light-tight dark tent) they would need for sensitizing and developing. In short, wet-plate photographers had to bring their darkrooms and studios along with them into the field.

Nonetheless, despite these difficulties, wet-plate technology quickly supplanted the daguerreotype in Canada and became the primary photographic process used on exploratory expeditions for the next several decades. It continued to be used even after the development of other less troublesome photographic methods that greatly reduced

${ }^{5}$ Collodion was comprised of gun cotton dissolved in ether and alcohol to which soluble iodine and often a bromide was added. A cleaned and polished piece of glass was coated with this honey-thick, iodized collodion, then sensitized in a bath of silver nitrate. The plate was placed in a light-tight holder which was placed in a camera and exposed immediately - while the collodion was still wet, hence the name "wet-plate"-then promptly developed using either pyrogallic acid or iron sulphate. After fixing the 
the time and materials needed, particularly for field work. Not surprisingly, economic factors played a key role in the persistent use of wet-plate photography in the face of other technical advancements. Unlike daguerreotypes where the image fixed on the metal plate was the final_and only-photographic print, the glass plate in wet-plate photography acted as a negative, enabling photographers to make multiple copies of a single image. Given the popularity of distant and exotic places, and the need for such depictions to complement travel and adventure literature, the potential profit which could be wrought from expeditions' photographs must have been appealing. Even before the Assiniboine and Saskatchewan Exploring Expedition had departed, Hind, aware of this interest in colonial explorations, made arrangements with the London Illustrated News - a highly popular serial publication that depended heavily on reproduced images-to have engravings drawn and printed from "a series of sketches...either drawn by hand or taken by photograph during the proposed exploration...." Instead of having to take multiple photographs of the same scene, a photographer would only have to take its likeness once. The comparatively modest cost of glass made the wet-plate process inherently cheaper than the daguerreotype, and the capability to produce multiple prints further defrayed costs. In other words, wet-plate photography's glass negative provided a means through which costs in materials and time could be recouped. Weston Naef and James Wood have suggested that it was this aspect of wet-plate photography that

image with a potassium cyanide solution, the plate was finally allowed to dry.

${ }^{6}$ National Archives of Canada. Provincial Secretary's Office Canada West. Record Group 5, C 1, Vol..578-579, 1858, No.907, H.Y. Hind to the Provincial Secretary, Toronto, 23 April 1858. 
stimulated outdoor work. ${ }^{7}$ William Notman's funding for Baltzly and Hammond's efforts in the $\mathrm{BC}$ interior had swift and obvious benefits. Within a week of returning to Victoria, Baltzly sold enough photographic prints to recover two-thirds of Notman's investment. $^{8}$

There had been numerous attempts to devise glass plates that were prepared in advance and could be developed when the photographer returned to the studio. Advantages for using "dry-plate" photography ${ }^{9}$ in the field were immediately apparent. Like wet-plate photography, the dry-plate process resulted in a negative from which numerous prints could be drawn. Moreover, the dry-plate process was much less cumbersome than its predecessor. Since all chemical machinations did not have to be done in situ, the demand for a photographer to bring along a darkroom was eliminated. This would, theoretically, reduce the amount of equipment that to be hauled through hundreds of miles of rough territory - thereby lowering the associated expenses-as well as the total amount of time needed to create a photographic plate. Early prepared plates though had a reputation for unreliability, decreased image quality, and extraordinarily long exposure times. Alexander Henderson, regarded as one of the most outstanding early amateurs using wet-plate photography in Canada, experimented with a variety of dry-plate processes in the late 1850 s but preferred wet-plate as he did not find much

\footnotetext{
${ }^{7}$ Weston Naef and James Woods, Era of Exploration (New York, 1975), 15.

${ }^{8}$ Christopher Jackson, With Lens and Brush (Calgary, 1989), 25, 27.

${ }^{9}$ Commercially prepared dry plates had been supposedly available in Canada since 1858, but high cost and slow emulsion speed curtailed their wide-spread use. Ralph Greenhill and Andrew Birrell, Canadian Photography, 1839-1920 (Toronto, 1979), 112.
} 
success with any of them. In a letter to The Photographic News in 1859, Henderson stated that:

Fothergill I gave up for the marbling....and the collodio-albumen would not work at all. ... This caused me disappointment in two excursions into the woods, where I saw fine subjects and took many [photographs], only to find black, dirty glasses on retiring. ...I very much doubt if I ever take a dry plate again, unless in winter. ${ }^{10}$

Although Henderson's photographic motives were largely artistic in origin, differing from the more scientifically-oriented photographers on survey expeditions, his statement nonetheless demonstrates the inconsistency of early dry-plate photography. Charles Horetzky, however, used dry plates with great success on the Canadian Pacific Railway surveys during the 1870s. "Less encumbered with equipment," as Edward Cavell writes in his article "Image of Transition: Photography in Rupert's Land," Horetzky was able to "respond to situations with more spontaneity." ${ }^{11}$ This was due either to Horetzky's remarkable good fortune in the quality of his plates, or attests to his ability as a photographer to produce consistent results with an unpredictable medium. Regardless, dry plates did not succeed wet-plate photography until the early 1880 s in Canada when technical developments created emulsions of greater reliability in addition to being ten times faster than conventional wet-plate.

Therefore, while dry plates offered an enticing promise of "easy" outdoor photography, a reduction in image quality and instability of the chemistry made wet-plate-with all its inherent complexities— the most viable option for expeditionary photographers during

\footnotetext{
${ }^{10}$ Birrell. "The Early Years," 6.

${ }^{11}$ Edward Cavell, "Image of Transition: Photography in Rupert's Land," Rupert's Land: A Cultural
} 
the third quarter of the nineteenth century. Naturally, for scientifically and geographically-based expeditions where the fundamental goal was to gather information and obtain a supposedly truthful impression of an unknown region, it was only reasonable that the method which seemed to best suit their needs was employed. Victorian demands for accuracy and copious detail seemed to support the belief that wetplate was the foremost medium to convey visual information. There were more practical reasons as well. The wet-plate technique simply remained the most reliable photographic process. A photographer could achieve a more consistent level of image quality using this process over others available-and this was a critical factor for exploratory photographers. If negatives were not to be developed until the expeditions returned to "civilization," there was virtually no way for photographers to retake the view if the negative yielded no image. Wet-plate photography allowed the photographer to know immediately — on site-whether a picture had been successful or not. Though complex and arduous, wet-plate remained the best option for expeditionary photographers for decades.

\section{Experiences in the Field: Mosquitoes and Locusts and Rain}

Nineteenth-century expedition photographers-far from metropolitan centres-were required to convey enough supplies to last several months. This substantially increased both the bulk of fragile equipment to be transported across vast distances and rough territory, as well as the cost of the whole expedition. Glass plates, bottles for chemicals 
and other fragile necessities demanded protective packaging, inflating their bulk and weight and making them extremely awkward to transport. Moreover, the glass plate negatives had to be the same size as the final photographic prints. Thus, Benjamin Baltzly's 8 x 10 negatives taken on the 1871 Geological Survey of Canada meant that the expedition party had to transport a multitude of $8 \times 10$ glass plates through the mountains. Needless to say, breakage was a constant fear as there was no way to replace materials or images lost. Both Baltzly and Humphrey Lloyd Hime came close to losing the whole of their work during the course of their travels, each during a portage. ${ }^{12}$

Hime nearly lost his negatives while crossing the White Mud River south of Fort Pelly. In spite of efforts to keep the carts from tipping, the first cart, men, and horses were all tossed about in the rapids. As he wrote in his journal: "I had the satisfaction of seeing my photographic apparatus, my gun, my clothes and all my little property submerged, fortunately they were tied tight and did not get out of the cart." Hime's baggage, though soaked, was "not much damaged." ${ }^{13}$ Richard Huyda has argued in is work Camera in the Interior that the "heavy staining and deterioration" visible in Hime's Qu'Appelle Valley photographs may be due in part to this accidental soaking. ${ }^{14}$ Baltzly's negatives suffered from a similar experience. While traversing the Murchison's Rapids, the canoe containing the whole of his $8 \times 10$ negatives was overturned, and all its contents were thought lost. However, when they retrieved the canoe, they found, by

\footnotetext{
${ }^{12}$ Andrew J. Birrell, Benjamin Baltzly: Photographs and Journal of an Expedition Through British Columbia, 1871. (Toronto: Coach House Press, 1978), 15.

${ }^{13}$ National Archives of Canada, Humphrey Lloyd Hime Papers, MG24, H87. Diary, 27 July 1858.

${ }^{14}$ Richard Huyda, Camera in the Interior: 1858 (Toronto, 1975), 16-17.
} 
some twist of fate, that the box containing the negatives had been wedged under the crosspiece. There was no breakage and the negatives were in perfect condition-after they had been dried. ${ }^{15}$

The costs incurred from hauling all these materials across, around, and through rough terrain were extraordinary. In addition to paying the photographer's salary and furnishing his supplies, expeditions were also responsible for paying for the extra animals and equipment needed to physically transport them. For example, even with William Notman paying Baltzly and John Hammond's salaries and providing the photographic equipment and supplies for the 1871 Geological Survey, the cost for merely transporting these two men and their materials was over $\$ 3000$-nearly half the cost of the entire geological expedition. ${ }^{16}$ Alfred Selwyn, upon writing to Sandford Fleming, Chief Engineer of the Canadian Pacific Railway, to justify the expense entailed by the inclusion of photography explained that "the great weight of the photographic apparatus (nearly 500 lbs.) has made the cost of the photographic branch of the expedition proportionately larger than that for geological purposes." 17

Inconvenience and expense aside, the wet-plate process was further complicated by the sensitivity of the materials used. Each negative took at least three and a half hours to complete, although five or six hours is probably a more realistic estimate, ${ }^{18}$ accordingly there were numerous opportunities throughout the procedure for something to go wrong.

\footnotetext{
${ }^{15}$ Baltzly in the Gazette, 28 July 1872.

${ }^{16}$ Birrell, Benjamin Baltzly, 17.

${ }^{17}$ As quoted in Birrell, Benjamin Baltzly, 18-19.

${ }^{18}$ This time frame accounts for the time the photographer unpacked the equipment to when it was repacked. Huyda, 45.
} 
The smallest impurity in the silver nitrate bath or in the water could result in a wasted plate and wasted time - a commodity not in abundance on expeditions. Huyda postulates that the "decomposition" evident in many of Hime's photographs may be due the use of an impure water source. ${ }^{19}$ Even the local wildlife seemed to conspire to nullify a photographer's labours. Frederick Dally, working in British Columbia and photographing the progress of the gold fields during the 1860 s had to re-take a photograph he took from Little Bluff on the Thompson River because "... a rattler happened to be under the stone that I had rested my plate against to dry in the sun, and licked the water off, marking the plate from the top to the bottom with its forked tongue." ${ }^{20}$

Weather conditions were another impediment to outdoor wet-plate photography. As can be expected, the chemistry of wet-plate photography was vulnerable to atmospheric conditions and environmental variables, and photographers had to adjust chemical compositions, exposure and processing times to compensate for these fluctuations. For example, collodion was susceptible to uneven coating and crystallization in cold weather. Indeed, the unpredictable aspects of nature often precluded any attempts to take a photograph. Hime, in the process of developing a picture of the junction of the Beaver and Assiniboine Rivers, for example, found his efforts wasted when the "tent blew down and destroyed it." ${ }^{21}$ In general, the 1858 Assiniboine and Saskatchewan Exploring Expedition was plagued by wet weather and locusts; both were both frustrating and destructive. As Hime reported in his diary on June 24, 1858: “...the grasshoppers

\footnotetext{
${ }^{19}$ Ibid., 19-20.

${ }^{20}$ Brock J. Silversides, Waiting for the Light (Saskatoon: Fifth House Ltd., 1995), 8.
} 
swarm[ed] where we breakfasted, ...eat[ing] through the saddles, quilts, canvas and leather bags, tents, coats, and everything that was not made of iron."22 Photographers in the mountains were particularly subjected to the vagaries of the elements. As Christopher Jackson writes: "rain, snow, cold, heat, fog, clouds, winds... and generally capricious visibility all contributed to the adversities of shooting in the mountains."23 Charles Wilson, Royal Engineer and possibly one of the photographers on the North American Boundary Commission, found the near constant rain especially oppressive. He lamented on December 23, 1858 that "it rained so hard that I could not keep my cigar lighted and had not even that comfort."24

\section{The Reality of Peopled Landscapes}

It is apparent that due to the technical intricacy of photography, the presence of staffage cannot be read as an "empty" gesture. The production of one, open-air, peopled landscape required a great deal of time and patience, regardless of which side of the camera a person was on. The nature of wet-plate photography was such that if figures were to be in the scene, they had to be in place prior to the plate's exposure. Potential staffage figures would have to wait patiently while the photographer prepared the plate as the emulsion was only sensitive when wet-there would be no time to put figures into position after the fact. Setting up the camera and framing the view could also extend the

\footnotetext{
${ }^{21}$ National Archives of Canada. Diary of H.L. Hime. Manuscript Group 24, H 87, 10 July 1858.

${ }^{22}$ Ibid, 24 June 1858.

${ }^{23}$ Jackson, 7 .

${ }^{24}$ Charles Wilson, Mapping the Frontier, George F.G. Stanley, ed. (Toronto, 1970), 42.
} 
amount of time spent waiting. As simple as these considerations may seem, their ensuing implications further support the argument that staffage functions beyond the documentary realm.

Firstly, staffage has often been dismissed as mere representations of a photographer's assistant(s). This may be a reasonable assumption, but it does not adequately explain why these individuals are on the other side of the lens instead of behind the camera where they would be of greater use to the photographer. Further, with the exception of John Hammond on the 1871 Geological Survey, there were no assistants on these missions; one photographer was expense enough, and another could scarcely be justified. Secondly, photographers on these missions generally had supplementary duties as well. Hime, for example, was also to participate in the mapping and cataloguing of the Northwest when he wasn't engaged in taking photographs. If photographers had multiple functions, and all the other party members had their own responsibilities to attend to, they had to take time away from their own duties to be photographed. An individuals' time to pose was further constrained by the speed at which these parties pushed (or attempted to) through vast amounts of territory.

Therefore, as the character of the medium precluded spontaneous images and professional responsibilities placed high demands on an individual's time, it becomes overwhelmingly obvious that the act of taking a photograph was a deliberate gesture. In their writings, expeditionary photographers do not mention their motivations for including staffage, nor do they account for the technical consequences of their inclusion. This absence suggests that the use of staffage by expedition photographers was 
unconscious, or perhaps resulting from established conventions, leading to assumptions that the appearance of these figures were accidents of circumstances. Nevertheless, the technical requirements of wet-plate photography belie these causalities. Unlike painting where an artist could add figures at will with a few dabs of paint, wet-plate photography did not allow for such flexibility. Staffage in photographs are not postscripts added on a whim, but rather their inclusion had to be given the same consideration as the rest of the scene. Thus, since the appearance of figures had to be premeditated, their presence must be indicative of some larger goal of the photographer or expedition leader. Even if staffage is being used to provide a sense of scale, it must be questioned, given the context of these photographs, why it was seen necessary to do so. Staffage then, did more than merely add a visual interest, but aided in the ideological encoding of a photograph.

\section{Photographic Authority: Concept of the Documentary}

Given the difficulties endured in producing photographs on exploratory expeditions, one can reasonably question why expedition leaders persisted using it under such extreme circumstances. Or, to put it another way, what aspect of photography proved so compelling that it was equally inconceivable not to include photographers on these missions? Traditional methods of sketching and painting had been found satisfactory for centuries, as well as being light, compact, and easily transportable, so why were they now determined to be a flawed and unreliable manner in which to transmit visual information? 
It should be noted that there were some individuals who felt that the expense and inconvenience of field photography did not compensate for the resulting images. On the 1858-82 North American Boundary Commission, expedition leader Lieutenant-Colonel John Hawkins "was so deterred by his own experience in obtaining photographs that he recommended against the use of photography on similar expeditions in the future." ${ }^{25}$ The American segment of the same commission did not have much luck either and eventually abandoned their equipment. Hind, leader of the Assiniboine and Saskatchewan Exploring Expedition, singularly disappointed by the blurred and distorted photographs taken in the Prairies, advised against using it again in the field. Alfred Selwyn's predecessor at the Geological Survey of Canada (GSC), Sir William Logan, was equally disenchanted by the wet-plate process. Logan declared that "the carriage of the photographic apparatus produced a delay in the geological work which was not sufficiently recompensed by the photographic results. ${ }^{26}$ Selwyn himself, even though he included Baltzly on his 1871 Geological Survey eventually came around to Logan's point of view. Although Selwyn, unlike Hind, appeared quite satisfied with the photographic result, declaring Baltzly's images to be "very beautiful and interesting," he found that the costs incurred acquiring them unjustifiable. ${ }^{27}$ Selwyn was so dismayed at the expense that he refused Baltzly's request in 1872 to set up a photographic department within the GSC. ${ }^{28}$ For Selwyn, whatever intrinsic value the photographs may have possessed was

\footnotetext{
${ }^{25}$ Birrell, Benjamin Baltzly, 19.

${ }^{26}$ As quoted in Greenhill and Birrell, 112.

${ }^{27}$ Birrell, Benjamin Baltzly, 18.

${ }^{28}$ Greenhill and Birrell, 112.
} 
nullified by their economic consequence. Yet, for all these protestations, photography continued to be used on expeditions. Indeed, for the GSC, it eventually became an indispensable documentary tool.

As mentioned briefly in the previous chapter, visual information was of paramount importance because it recompenses, in the words of Captain Cook, the "inevitable imperfections of written accounts. ${ }^{, 29}$ As Ronald Rees points out in his catalogue Land of Earth and Sky, the Euro-English lexicon lacked the terms to describe adequately the new animals, peoples, and forms encountered in the "New World":

Europe had no buffalo, Indians or voyageurs, and English no words for a vast, empty plain or for such features as sloughs, coulees, or poplar bluffs. The old words_-dale, lakelet, heath, meadow-didn't fit the new context. In new lands, as in no other settings, a picture was worth far more than the proverbial thousand words. ${ }^{30}$

Official expeditions generally had included in their ranks at least one officer whose cardinal duty was to make sketches of landscapes encountered, emphasizing the forms, details, and relationships of geological structures. During the nineteenth century, as European faith in the infallibility of science gained primacy, there was increased pressure on artists to produce works with a high degree of verisimilitude. Because the natural world was believed to conform to universal laws which conditioned nature's structural organization, it followed that artists should adhere to the same principles. ${ }^{31}$ Faithful study was a means of understanding the physical world, and accurate drawings were avenues to that end.

\footnotetext{
${ }^{29}$ Ronald Rees, Land of Earth and Sky (Saskatoon: Western Producer Prairie Books, 1984), 4.

${ }^{30}$ Ibid.
} 
Photography's emergence at this time can be viewed as a consequence of this objectification of the natural world. The drive for realistic representation in art coupled with a fascination with science and the mechanical made the invention of photography a reality. ${ }^{32}$ Victorian society was obsessed with the need to classify-precisely-the contents of the entire planet, and the apparently impartial eye of the camera was viewed an ideal tool to aid in the accumulation of statistical detail, observation, and codification. Machines to aid in the transcription of nature were hardly a new idea. Since the Renaissance, devices such as the camera obscura and camera lucida had been devised and utilized to assist in reproducing a three-dimensional space on a twodimensional surface. ${ }^{33}$ The closer an image came to recreating how reality is perceived by the human eye, the more useful it became. However, the quality of the final results wrought from these tools ultimately depended on the draughtsmanly skill of the user, and thus was subject to imperfections in the hands of a person of inadequate ability. The mechanical nature of photography seemed to transcend human intervention-thus human biases_-and was believed to bring forth an impartial, unmediated representation of the natural world. To quote Jennifer Green-Lewis from Framing the Victorians: "Photography's prescriptive powers were greater than those of a painting in part because a photograph looked more like the thing it was supposed to represent...."34 Furthermore, the apparent lack of human authorship implied that Nature drew itself on the

\footnotetext{
${ }^{31}$ Jackson, 61.

${ }^{32}$ Price and Wells, 20.

${ }^{33}$ Doug Nickel, "The Camera and Other Drawing Machines," British Photography in the Nineteenth Century, Mike Weaver, ed. (Cambridge, 1989), 3.

${ }^{34}$ Jennifer Green-Lewis, Framing the Victorians (Ithaca, 1996), 25.
} 
photographic plate; and since Nature was the manifestation of God, this also connoted that the image was Truth. In short, photographs were seen to document reality and to provide unbiased evidence of the state of the world—and Victorians' place within it.

The photographs discussed in this work have often been labeled "documentary" because they were done under the auspices of government surveys and expeditions. However, this label was applied after the fact, and nineteenth-century photographers did not consciously construct their images under this rubric. The term was actually coined by John Grierson in 1926 in order to distinguish the type of film he wanted to supplant what he saw as "the dream factory of Hollywood."35 Documentary, as a category label, was quickly adapted by photography as it seemed to cleave to many of its defined tenets. William Stott, in his influential book Documentary Expression and Thirties America defined "documentary" as a form which

...defies comment; it imposes its meaning. It confronts us, the audience, with empirical evidence of such nature as to render dispute impossible and interpretation superfluous. All emphasis is on the evidence; the facts themselves speak... The heart of documentary is not form or style or medium, but always content. ${ }^{36}$

Nineteenth-century expeditionary photography seemed especially susceptible to this characterization of content over style given its genesis as a tool of scientific recordkeeper, and made a certain amount of sense considering that, as a designation for visual

\footnotetext{
${ }^{35}$ Price, 63.

${ }^{36}$ William Stott, Documentary Expression and Thirties America (London, 1973), 14.
} 
imagery, documentary was applied to the indexical and the objective rather than to the iconic. $^{37}$

However, while some nineteenth-century photographers may have regarded their works as being "documents," many would not have realized they were "documentary" photographers. As Abigail Solomon-Godeau points out in Photography at the Dock:

The late arrival of the category documentary into photographic parlance implies that until its formulation, photography was understood as innately and inescapably documentary in function. ...[T]o nineteenth-century minds the very notion of documentary photography would have seemed tautological. ${ }^{38}$

For Victorians, the perceived indexical function of photography was self-evident, and its status as evidence was immutable. As Victor Burgin argues in "Photographic Practice and Art Theory," unlike linguistic signs which are arbitrary-there is nothing to demand that the linguistic sign be congruous with the object it represents - for a photograph, the sign and signifier, referent and image are inextricably linked. ${ }^{39}$ The photographic image is caused by its referent because the technical nature of photography stipulates that the object be present when the plate is exposed. ${ }^{40}$ Roland Barthes, in his work Camera Lucida states that it is "as if the Photograph always carries its referent with itself. ... [T]hey are glued together...."41

\footnotetext{
${ }^{37}$ Abigail Solomon-Godeau, Photography at the Dock: Essays on Photographic History, Institutions, and Practices (Minneapolis, 1991), xxvii.

${ }^{38}$ Ibid., 170.

${ }^{39}$ Victor Burgin, "Photographic Practice and Art Theory," Thinking Photography, Victor Burgin, ed. (Houdmills, 1982), 61.

${ }^{40}$ Ibid.

${ }^{41}$ Roland Barthes, Camera Lucida (New York, 1981), 5-6.
} 
This connection gave photographs their powerful communicative presence, but it is also what fostered their conception as transparent objects-and thus a transparent conveyor of truths. When viewing a photograph, one is less conscious of the photograph as an object in and of itself than with the subject matter it depicts. A person sees a rolling landscape, a gnarled tree, or a snow-capped mountain, but rarely does someone see the photograph itself. ${ }^{42}$ Eliminating the distance between image and referent reinforced the conception that photographs were purveyors of fact because they offered the illusion of intimacy with the photographed object. There seemed to be no mediator interpreting and re-constructing the view, thus the photograph seemed to extend a direct connection to the original. In other words, reality seemed to speak for itself, and reality, as an objectified entity, did not lie.

It is this aspect that gives photography its authoritative power. The indivisibility between image and referent apparently made translations of photographed "realities" unnecessary. The belief in photography's transparency actually served to make it a discursive tool that, if we go back to Stott, imposed meanings instead of creating them, disempowering the viewer-but empowering those who wielded photography as a device of ideological construction. ${ }^{43}$ According to Craig Owens in Beyond Recognition, perceptions of transparency were actually fundamental to photography's function as a device of cultural persuasion. The absence of authorship erased material and ideological supports that seemingly allowed reality to communicate unencumbered with the

\footnotetext{
${ }^{42}$ Ibid.; James R. Ryan, Picturing Empire (Chicago, 1997), 17.

${ }^{43}$ Stott, 14.
} 
viewer. ${ }^{44}$ Thus, the photograph seemed to be a truthful transcription of the physical world, objective and eminently trustworthy.

\section{The Photograph Abroad: Disseminating Images}

Finally, it is important to consider the dissemination of exploration photographs as a crucial factor. Although these photographs were made for official surveys and were used extensively in expedition reports to the government, they were often circulated to much larger audiences, reinforcing the cultural ideas which originally gave them form. Allan Sekula writes in his essay "On the Invention of Photographic Meaning" that the reproduction of these types of images "served as an ideologically-charged reification of the expanding boundaries of the state. ${ }^{145}$ As mentioned previously, because there was a fascination with pictures of far off and previously unknown places, ${ }^{46}$ a market for these kinds of images already existed. Transforming these photographs into objects available for consumption was another way of symbolically establishing a sense of possession of the territories depicted. Often, photographers of the time would publish their views in albums to be sold to the public. In 1860, thirty of Hime's photographs from the Assiniboine and Saskatchewan Exploring Expedition were printed in Britain in a portfolio entitled Photographs Taken at Lord Selkirk's Settlement on the Red River of the North to Illustrate a Narrative of the Canadian Exploring Expeditions in Rupert's Land that

\footnotetext{
${ }^{44}$ Craig Owens, Beyond Recognition, Representation, Power and Culture (Berkeley, 1992), 111.

${ }^{45}$ Allan Sekula, "On the Invention of Photographic Meaning," Thinking Photography, Victor Burgin, ed. (Houdmills, 1982), 95.

${ }^{46}$ Jean-Claude Lemagny, A History of Photography (Cambridge, 1987), 36.
} 
was to accompany the two-volume Narrative written by Hind. All accounts suggest that this set was very well received by the British press, but it is not known how many of these portfolios made it to Canada. ${ }^{47}$

However, survey reports to governments and photographic albums were not the primary means for circulating exploratory images. More common, and more accessible to the general public, was the copying or translation of photographs into woodcuts, engravings, and eventually lithographs, which were then published in books, journals, articles, and newspapers. The popularity of such illustrated newspapers as the Illustrated London News in Britain and the Canadian Illustrated News at home made wide-spread distribution of Northwestern images possible. The prevalence of artistic conventionsthe sublime and the picturesque-in supposedly documentary photographs reveals an awareness that these images were not restricted to an audience of government officials. Organizing views of the land through the imposition of culturally determined aesthetics was another means of controlling the land as it presented it as it was "ideally" conceived to be instead of as it actually was. ${ }^{48}$ The context in which images were produced, distributed, and consumed explains much about how they are interpreted, including their relationships to the subjects they describe. ${ }^{49}$

Nonetheless, it is curious to note that for all the claims about photography's objectivity and truthfulness, reproductions of expedition images in the popular press and travel literature often show marked differences from the original, although it is doubtful

\footnotetext{
${ }^{47}$ Huyda, 26.

${ }^{48}$ Richard Leppert, Art and the Committed Eye (Bolder, 1996), 8-9.
} 
that many would have had the photographs to compare to their prints. Nonetheless, it is valuable to point out the alterations, particularly since publishers generally stipulated whether a print was drawn from a photograph in order to certify the image's accuracy and validity. ${ }^{50}$ Christopher Jackson, in his exhibition catalogue With Lens and Brush notes that engravers and lithographers were subjected to the same aesthetic and stylistic principles as photographers—but compounded by economic concerns-and would alter their prints to produce an image that held the widest appeal. ${ }^{51}$ Consequently, these images shaped the public's conceptions of the Northwest as these reproductions had far greater circulation than the originals. ${ }^{52}$

Hime's expedition photograph The Prairie Looking West (fig. 12), discussed in the second chapter, provides a good example of how subsequent printing mediated images. It is known both as a photographic print as well as an engraving published in Hind's 1860 Narrative of the Canadian Red River Exploring Expedition of 1857 and of the Assiniboine and Saskatchewan Exploring Expedition of 1858 (fig. 22). At first glance, it becomes evident that the basic structure of the engraving is the same as the photograph: the ground is a broad, dark stripe with a skull in the foreground below a wider, lighter strip of sky. However, subtle differences in the print not only change its aesthetic appearance, but how it was interpreted as well.

\footnotetext{
${ }^{49}$ Bright, 133.

${ }^{50}$ Greenhill and Birrell, 64 .

${ }^{51}$ Jackson, 75 .

52 Ibid.
} 
First, the gradation of the land itself has been altered in the print, becoming lighter in tone along the horizon line-a convention typically found in landscape painting- that differs from the dark strip seen in the photograph. Second, and more obvious, is the sky. In Hime's photograph, the sky is completely blank due to the sensitivity of the collodion emulsion to blue light. Skies in wet-plate photography were generally overexposed for this reason, and any cloud detail present was obliterated. This limitation has been "corrected" in the print through the addition of clouds and tonal gradations that are somewhat evocative of a sunset, and go a long way to relieving the harshness perceived in Hime's photograph. However, some have argued that the blank sky in the photograph was deliberate. Photographers knew about collodion's sensitivity to blue and compensated for it. They also generally had a series of generic sky effects that could be inserted when making prints. Hime would have known about these tricks, but he did not use them in this photograph, and instead exploited the natural characteristics of collodion for effect. The starkness of the photograph is quite jarring; it seems more an image of "nothingness" instead of an actual place.

Lastly, although the skull appears in both images, preserving the memento mori effect, its impact has been lessened in the print. It has been moved further to the right, rather than prominently placed at the "dead-centre" of the photograph. This was not done to simply be more aesthetically pleasing; instead, moving it also helps to counterbalance the large, V-shaped flock of birds diagonally above the skull. This certainly stabilizes the image, but it also conceptually re-balances it as well. A symbol of death and its inevitability, the birds can be seen as a symbol of life; and together they represent the 
cyclical nature of the cosmos_a far more positive view than seen in the photograph. However, the flock of birds can also be read quite literally, representing the Northwest's ability to support life. Therefore, although the illustration seems as sublime as the photograph, alterations between the two impact not only its aesthetic appearance but how it was understood by viewers.

\section{In Summary...}

This chapter established the foundations for the technical consequences of staffage through a discussion of the technical nature of photography, the nineteenth-century concept of the "documentary," and how expeditionary photographs where seen by the public was necessary. In short, this chapter has dispelled certain assumptions and preconceptions about the photographs produced on exploration expeditions. It is quite apparent that wet-plate photography was very difficult to use in the field. Given these considerations, it is also obvious that the appearance of staffage figures in photographs was not an accident of circumstances. The deliberate nature of photography implies that what ever appears in the final image was deliberate as well.

However, despite these impediments, in the face of all the complaints about it, wetplate photography continued to be used repeatedly by expeditionary surveys. Indeed, some departments dispensed with topographical artists altogether. Photography's seemingly ability to transcribe reality directly made it an invaluable documentary tool for explorers and scientists. Given the increased societal demand for detail and accuracy, the increased use of photography in this capacity comes as no surprise. Further, as 
nineteenth-century viewers had no concept of the "documentary," these representations were not viewed as encoded images but instead were seen as slices of reality itself. Ironically, the distribution of photographic reproductions served to undercut all claims to objectivity publishers placed on these images. Transforming photographs into woodcuts and engravings inevitably changed how a photograph appeared, but deliberate aesthetic alterations not only altered the photographs appearance, it also changed how a print could be read by the public. 
C ONCLUSION

\section{Windows and Mirrors: "Reflections" on Staffage}

Therefore, this thesis has argued that staffage figures, despite their small size, were not mere ornamentation casually used to add to the visual interest to a photographic scene. Their frequent appearance in landscape photographs suggests staffage was an accepted convention that was used expressly to establish a human presence in a scene. I have shown that staffage figures in expeditionary photographs of Canada's Northwest served to reinforce preconceived notions of territorial acquisition-the presumption of ownership and control — that in turn, revealed expansionists' own colonial imperatives. As such, staffage was not an empty, neutral gesture, but was capable of aiding in the encoding of a photograph's message.

During this time of territorial conquest by certain European powers, white figures of European descent demonstrated the presence of not only individuals in distant landscapes, but seemed to verify their occupation of newly acquired areas. Photography appeared to offer "Edenic" images of the world, representations that had not been mediated through any human filter, for the indexical nature of photography seemed to imply a causality that stipulated that the photographic image was identical to the original object photographed. Thus, because photographs appeared to directly transcribe reality, images of people, places, and things in absentia were seen as being able to

\footnotetext{
${ }^{1}$ Victor Burgin, "Looking at Photographs," Thinking Photography, Victor Burgin, ed. (Houdmills, 1982), 144.
} 
substitute for the actual object. Photographs of distant foreign landscapes to the armchair tourist or government official thus seemed to offer direct contact with the original scene. Staffage served to further bridge the gap between object and referent, and act as "proof" of possession. To put it simply, because a person appeared in a photograph, they had to have actually been in that location, in front of the lens, at the time of exposure. Occupation becomes concrete, and in areas of the world that were largely unexplored and unsettled, staffage, through photography's apparent verisimilitude, verifies occupation by European powers.

Thus, staffage, so often overlooked in photographs, so apparently meaningless given their diminutive stature, so often dismissed as happenstance or superficial decoration has instead been posited as a bearer of meaning that was capable of aiding in the ideological encoding of a photograph. Their size seems to belie this proposed impact on photographic meaning, but it is this very aspect that makes staffage so very insidious. If their presence is taken for granted as a mere accident of circumstances, then their appearance in the photograph is somehow natural. Therefore, whatever role of meaning they were meant to impart is also seen as inevitable. Staffage may not be a blunt or obvious way of denoting meaning, but this apparent lack of impact should act as a warning that staffage cannot be overlooked.

I have contextualized this premise by constructing a social and cultural framework through which expeditionary photographs were examined. Canada's Northwest, perceived of as barren wilderness deemed unsuitable for "civilized" endeavours, underwent a conceptual re-visualization during the late 1850 s, due in part to imperialist 
imperatives that equated the possession of land with political power. The Northwest, apparently "empty" and unutilized, provided an ideal vehicle for the new Dominion to assert itself internationally, Thus, perceptually, it was transformed from arid hinterland and moral desert to a space of unruly fecundity where only colonial guidance was needed to make the Northwest a productive cog in the imperial machine. The Northwest was conceived as a vast field of resources simply lying in wait to be occupied by Europeans and Euro-Canadians; only then could it be considered a valuable asset to the Dominion and, by implication, the Empire. These ideas illustrated the belief that European and Euro-Canadian influences could tame both indigenous inhabitants and nature, and thus bringing order to what they perceived as an undisciplined wilderness. Surveys of the Northwest, in addition to documenting the topographical features of the region, in turn acted to record the imposition of this cultural ideology illustrating the assumed potential of the land more than its actual state.

Staffage, participated very directly in this transformative process, and put acts of colonial appropriation into a more practical context. The presence of European and Euro-Canadian figures in the landscape could simultaneously represent the Northwest's capacity to support settlement by performing as a device to provide scale, as well as act as a witness to the prospect of the country. Staffage figures, due to their small proportions, made the landscape seem that much grander, and thus seemed to demonstrate the vast amount of resources potentially available for harvest. Staffage also could act as a visual manifestation of the colonial goal to consume categorically the contents of the spaces they sought to occupy, using knowledge as a means to control and ultimately possess the 
land. Landscapes were further appropriated by the application of aesthetics that removed them from the natural, and making them objects to consume. As a representative of a colonial society, staffage not only foreshadowed the future "civilization" of the land, it also served to show its increased level of domesticity. Documenting their occupancy in the landscape reinforced the notion that the Northwest was under the control of the Dominion, along with strengthening the bond between Eastern and Western Canada. Therefore, staffage served as a physical symbol of colonial presence, and further instructed how the viewer was to read the photograph. Moreover, the technical complexity of nineteenth-century photography also shows that the appearance of staffage figures were not the result of coincidence. A photograph took a great deal of planning, so any objects that appeared in it had to be accounted for beforehand. This implies that if a figure was to appear in a photograph, there was a specific reason for doing do.

However, the images discussed here are only a small fraction of the wealth of expeditionary photographs, and only account for the initial penetration into the Northwest. How staffage was used, ideologically, in photographs during the next phase of terra cognita would be a valuable avenue of research. Specifically, it would be worth examining the use of staffage in photographs of the construction of the Canadian Pacific Railway, and in those images used by officials to promote the West as a place of settlement. Also, this thesis has limited its focus to "single" images; the use of staffage in stereoscopic photographs would also add a great deal to this area of study.

Ultimately, I have determined that a great deal of staffage's potential discursive power is intimately connected to nineteenth-century concepts of photography. At that time, 
photographic images were often though to act like mirrors and windows. On the one hand, this can be taken quite literally: the silvered surfaces of daguerreotypes and the use of glass for negatives for wet-plate photography probably made these associations inevitable. On the other hand though, these analogies can be interpreted as an indicator for how contemporary audiences viewed photographic content. A product of chemical and mechanical processes, the apparent verisimilitude of photographic images seemed to suggest that photography enabled Nature to reproduce itself. Representations then, appeared to reflect an exact replica of the photographed object, or open a window directly into a slice of reality. However, both mirrors and glass, if taken literally, are inherently reflective, suggesting that a photograph's content is inextricably linked to the viewer, revealing their beliefs and values as much as the subject matter of the photograph. Placing staffage in photographs is a very direct way of projecting oneself into the image, and reinforce preconceptions about the object photographed. 




Figure 1. Group in Elora Gorge, Ontario, J.R. Connon, 1895. 


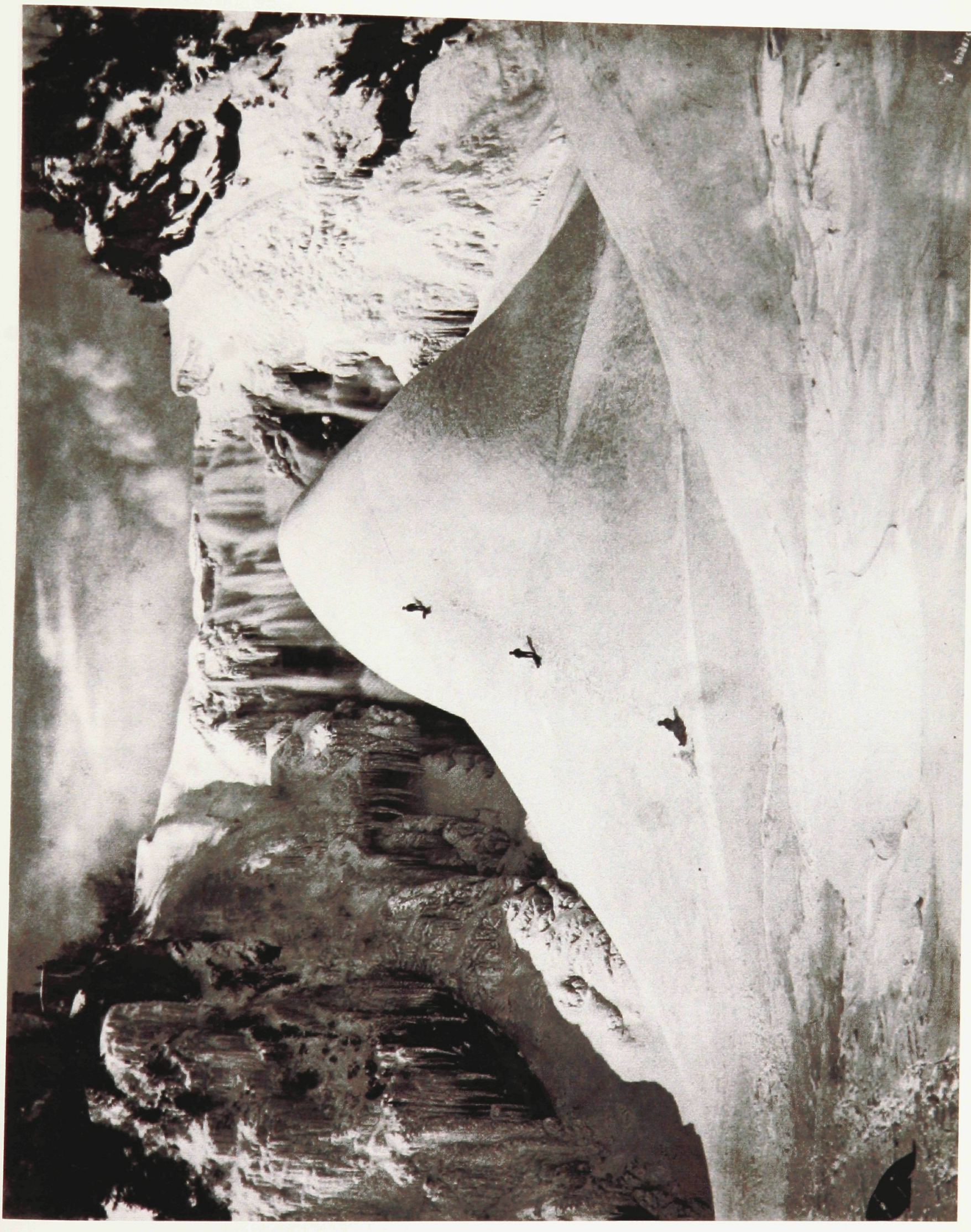

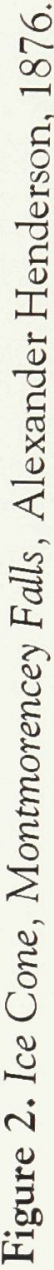






Figure 3. Lake Louise, From N.E., William Hanson Boorne, undated [1885-89]. 


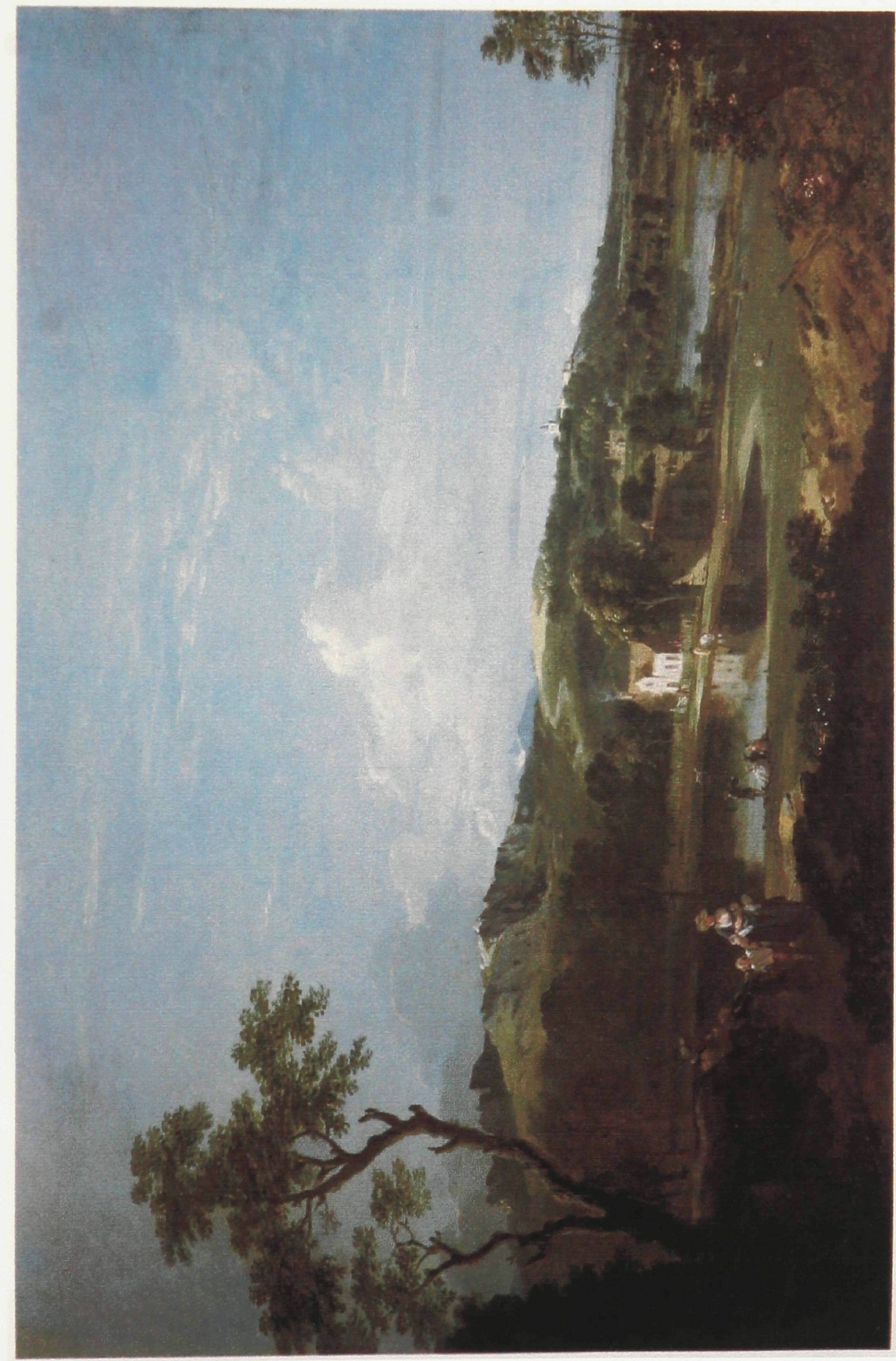

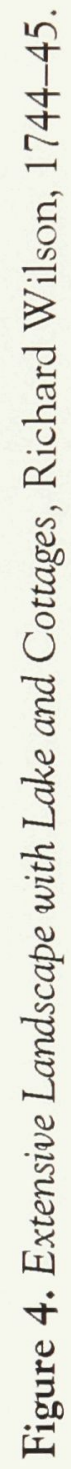




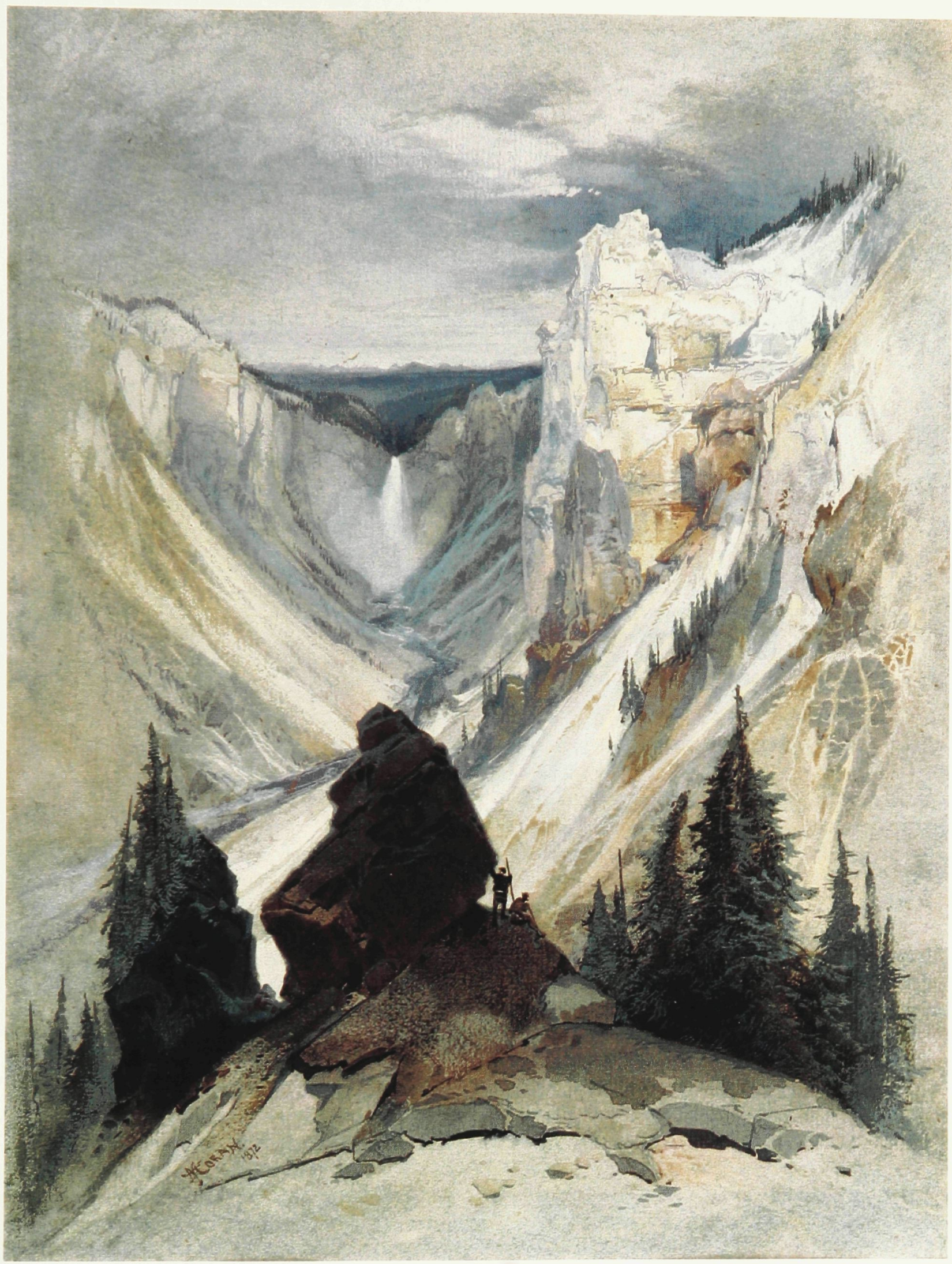

Figure 5. The Grand Canyon of the Yellowstone, Thomas Moran, 1872. 


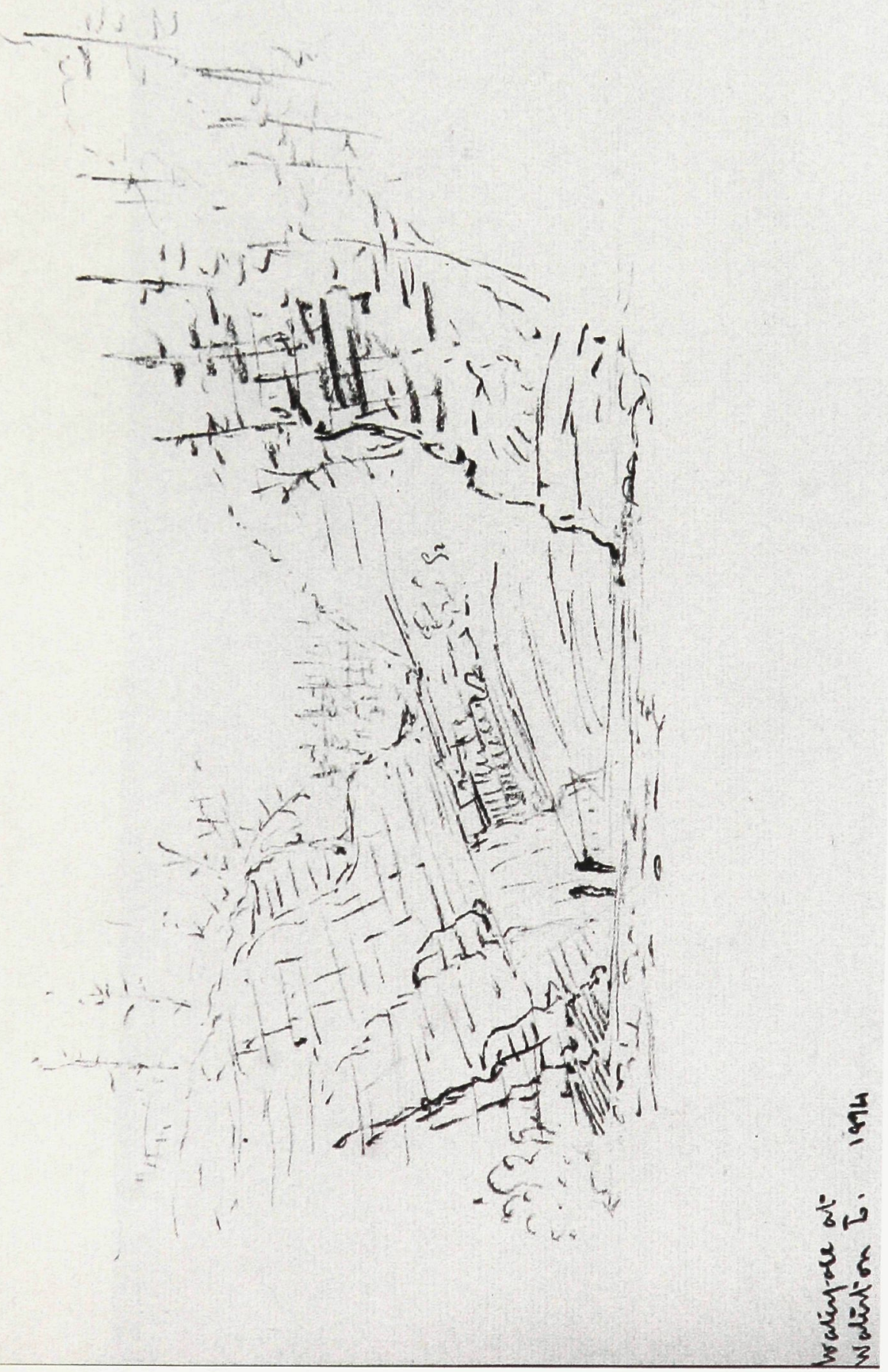




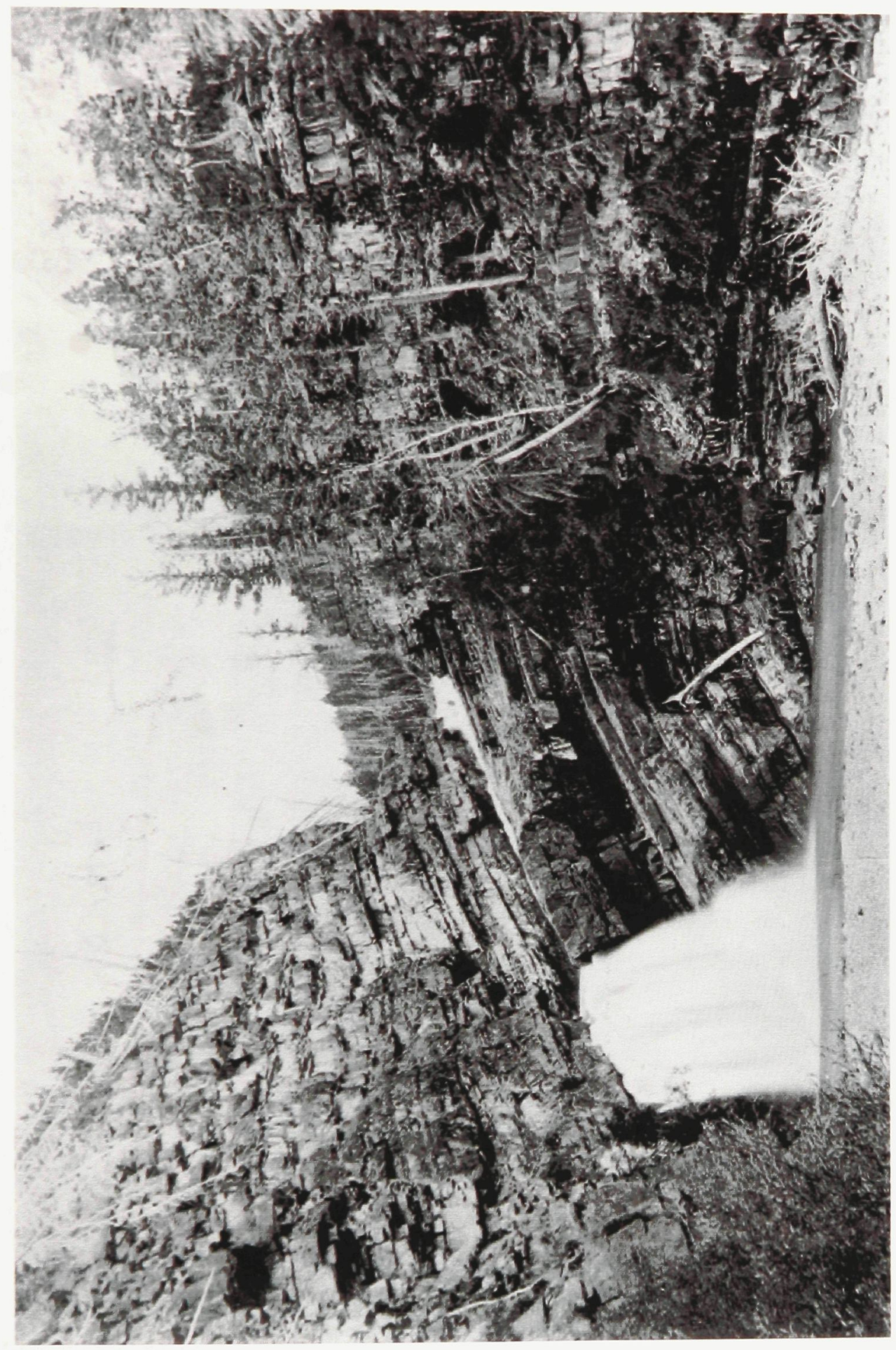






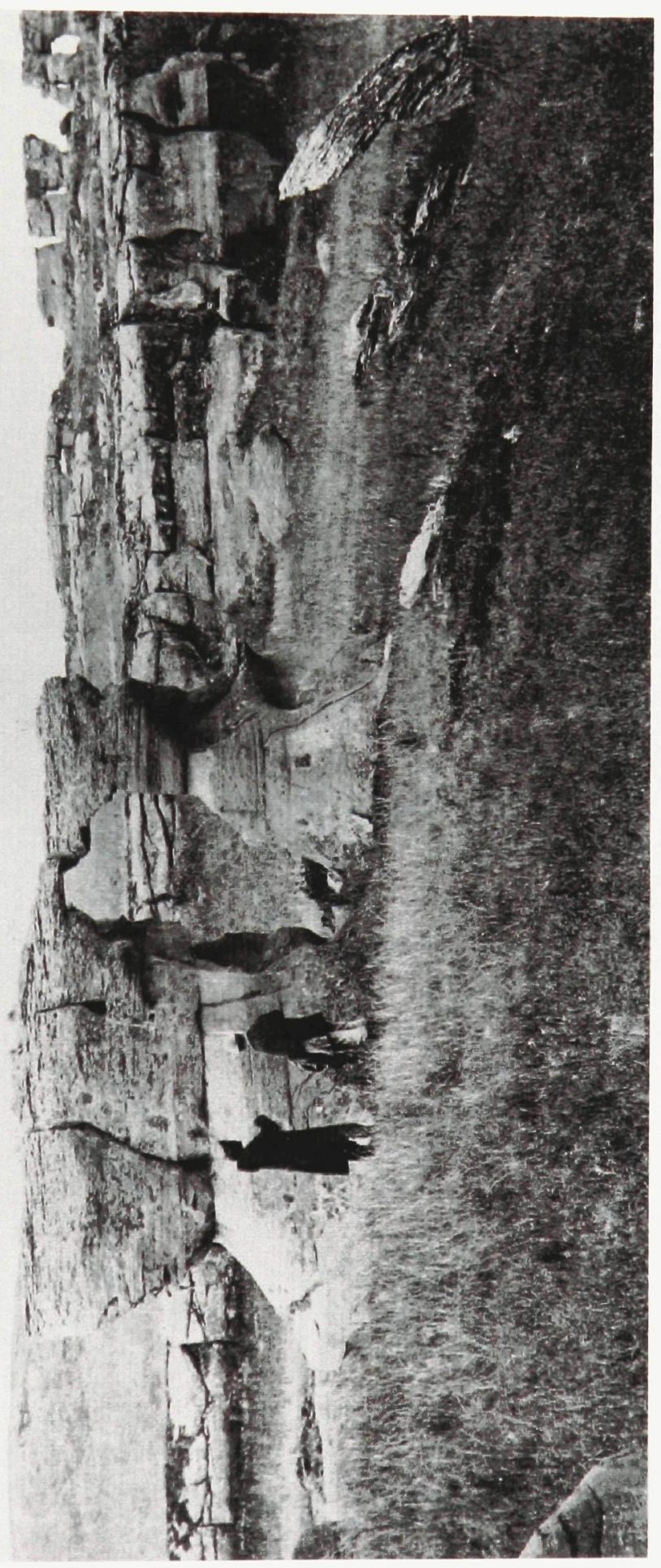

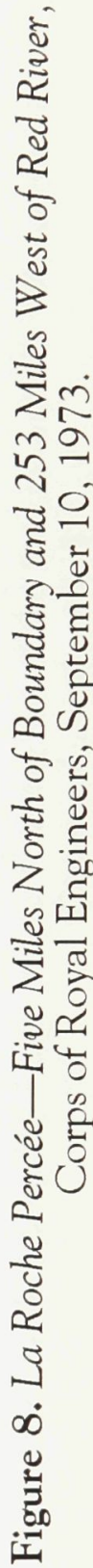




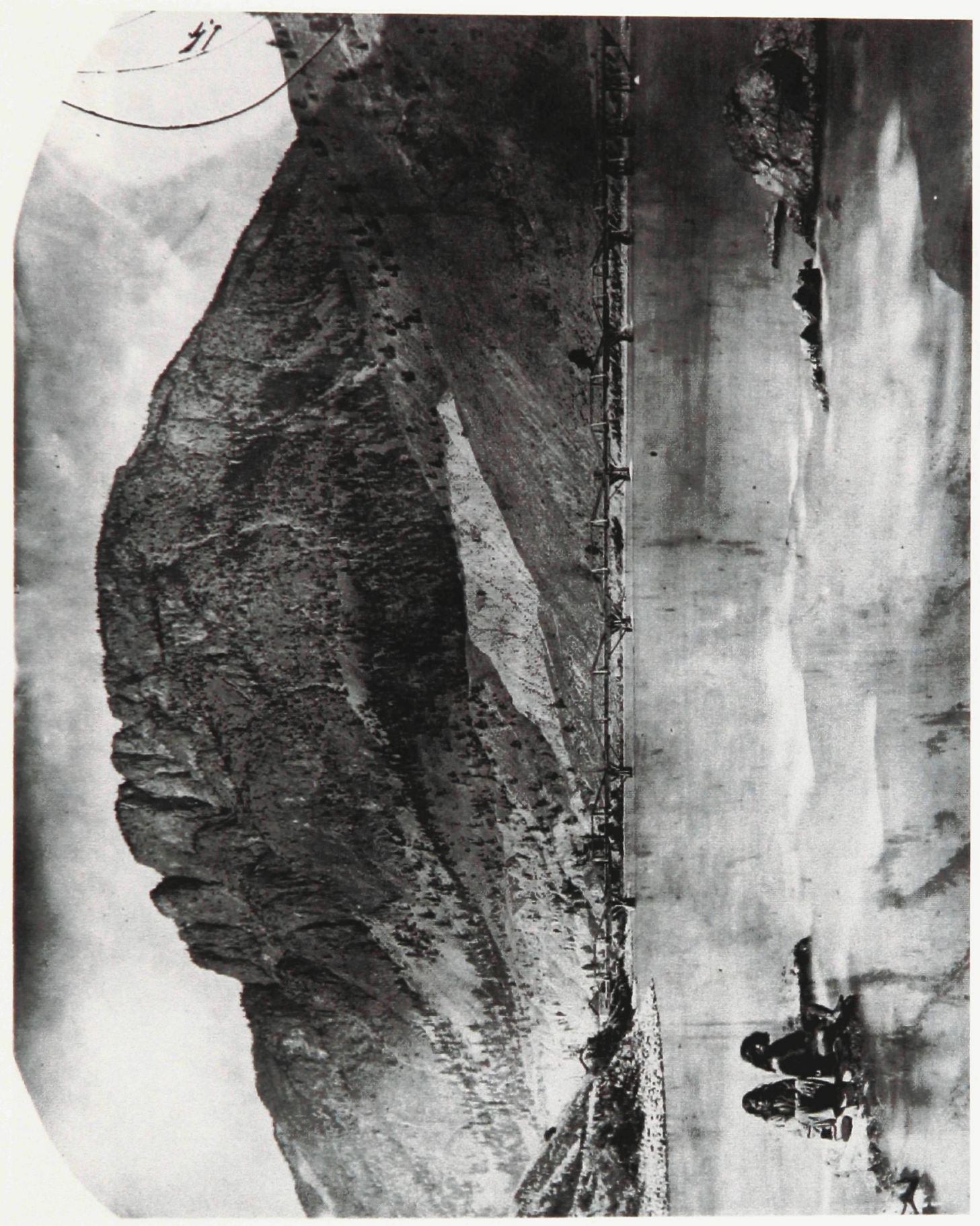

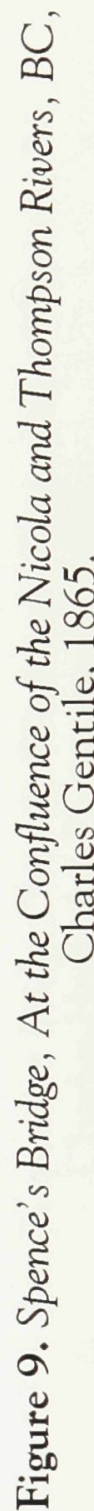




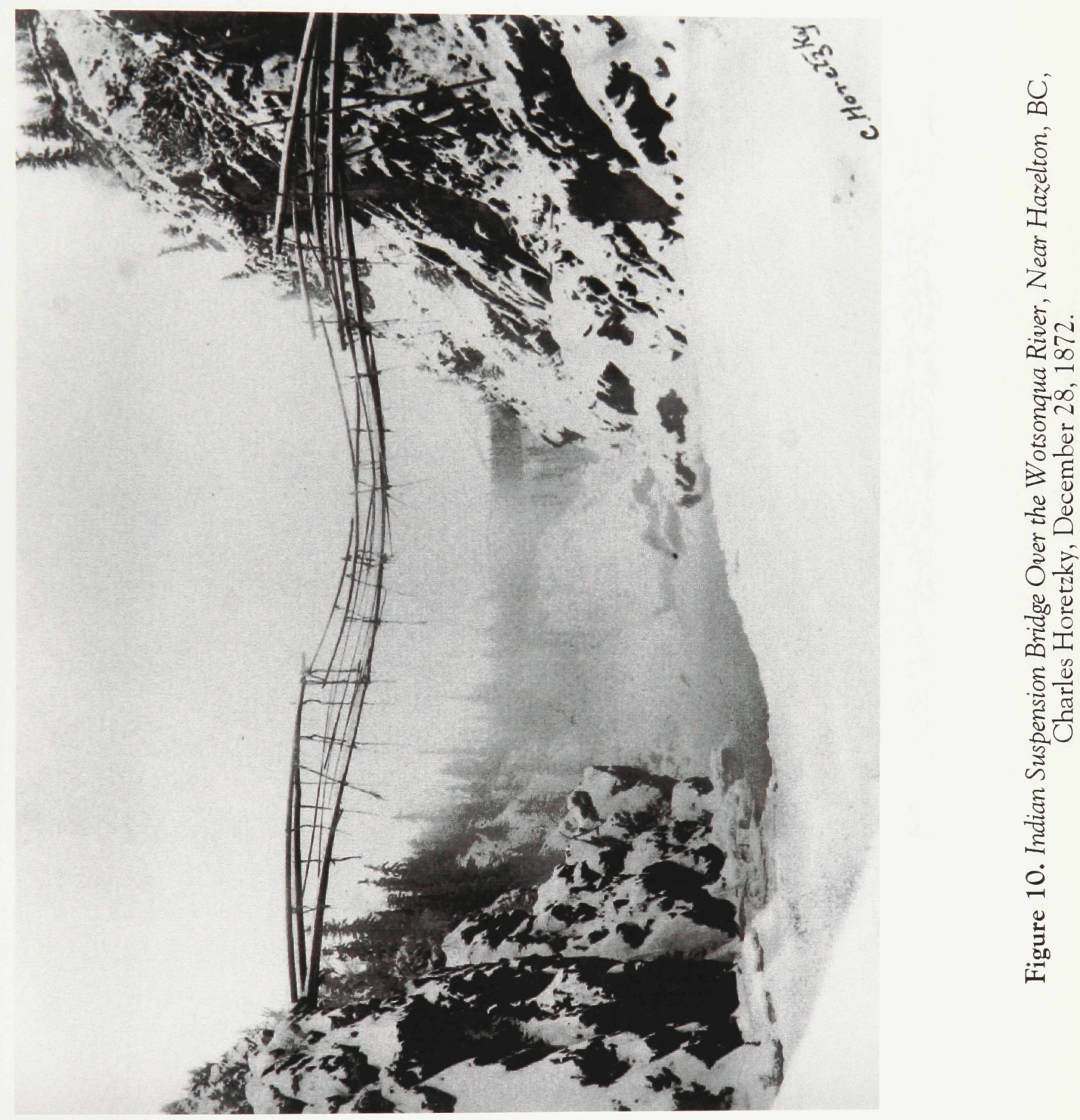


















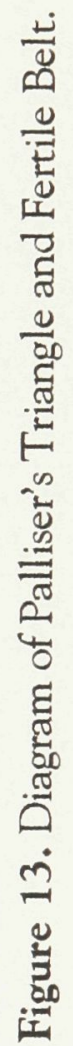




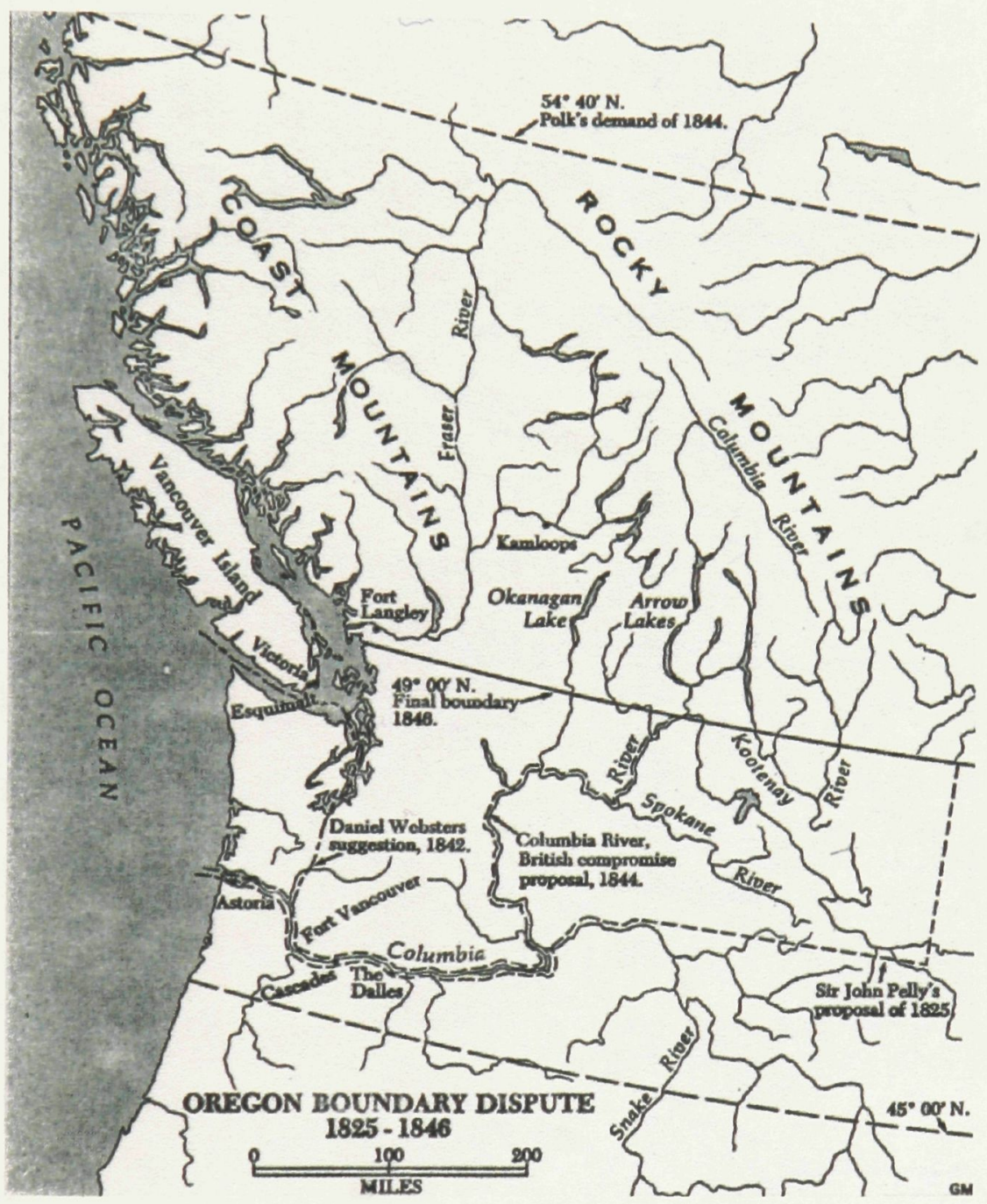

Figure 14. Diagram of the Oregon Boundary Dispute, 1825-46. 


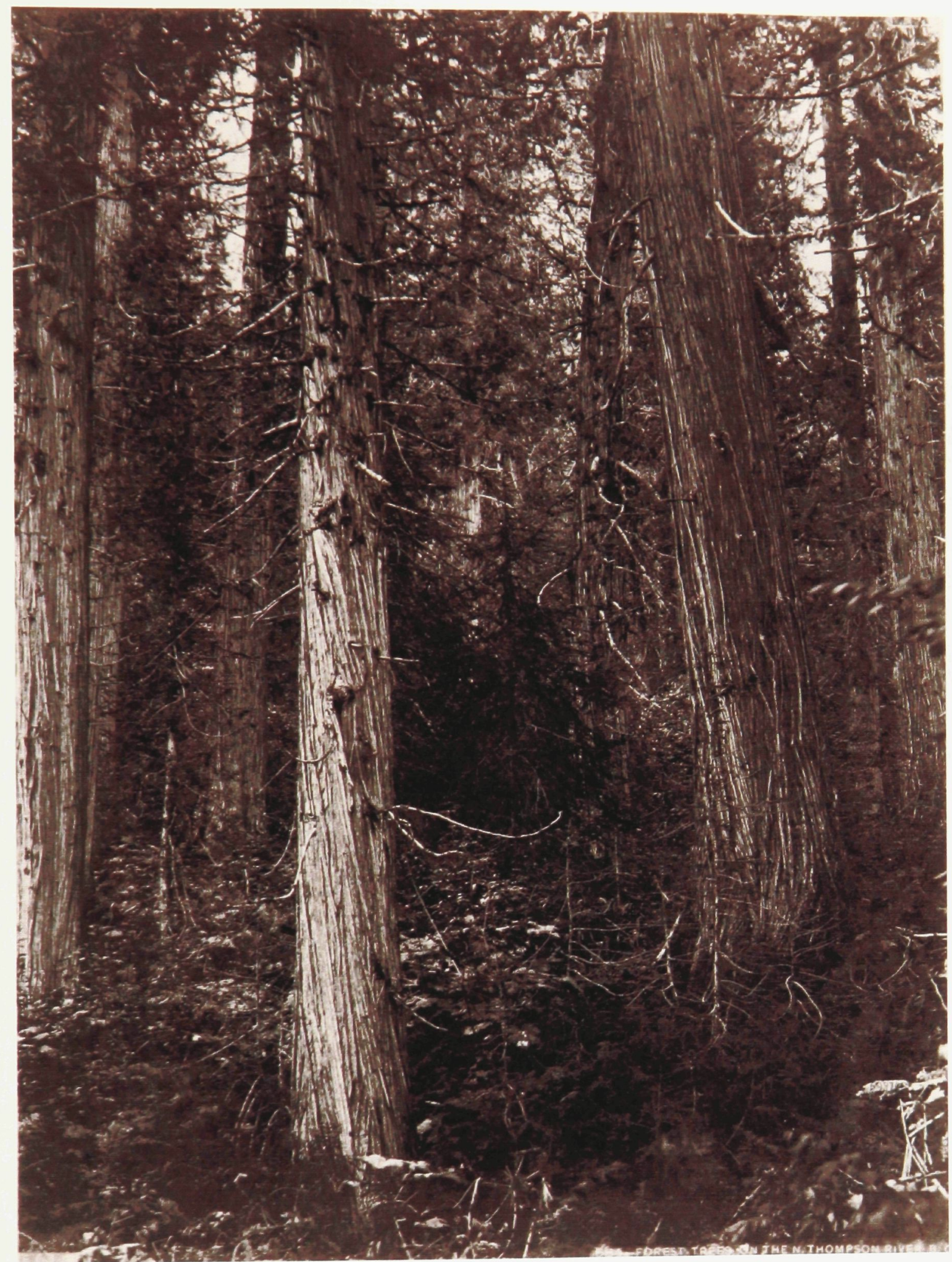

Figure 15. Forest Scene on North Thompson River, 165 Miles Above Kamloops, BC, Benjamin Baltzly, September 20, 1871. 


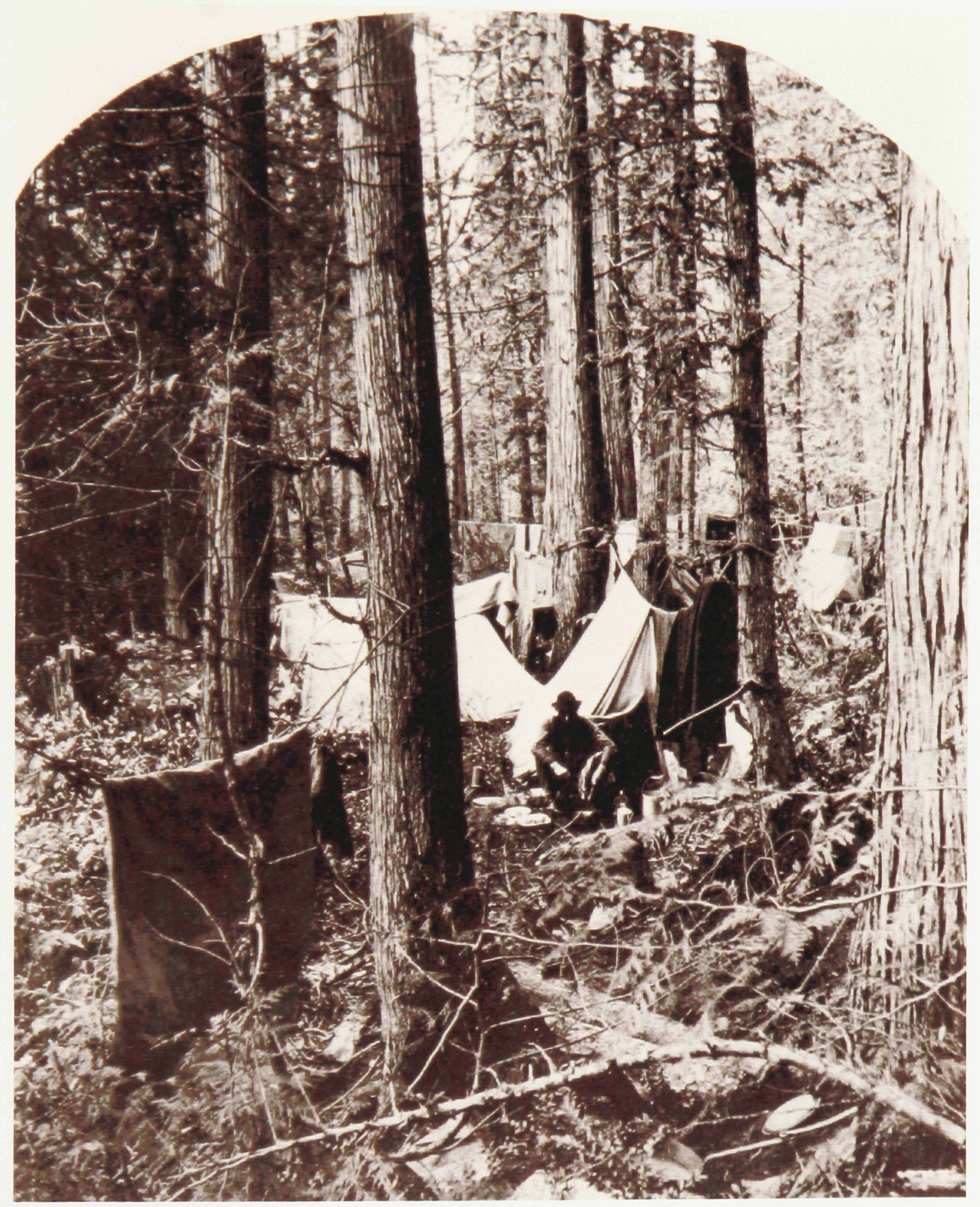

Figure 16. Geological Survey Camp on the North Thompson River, 165 Miles Above Kamloops, Benjamin Baltzly, September 20-24, 1871. 


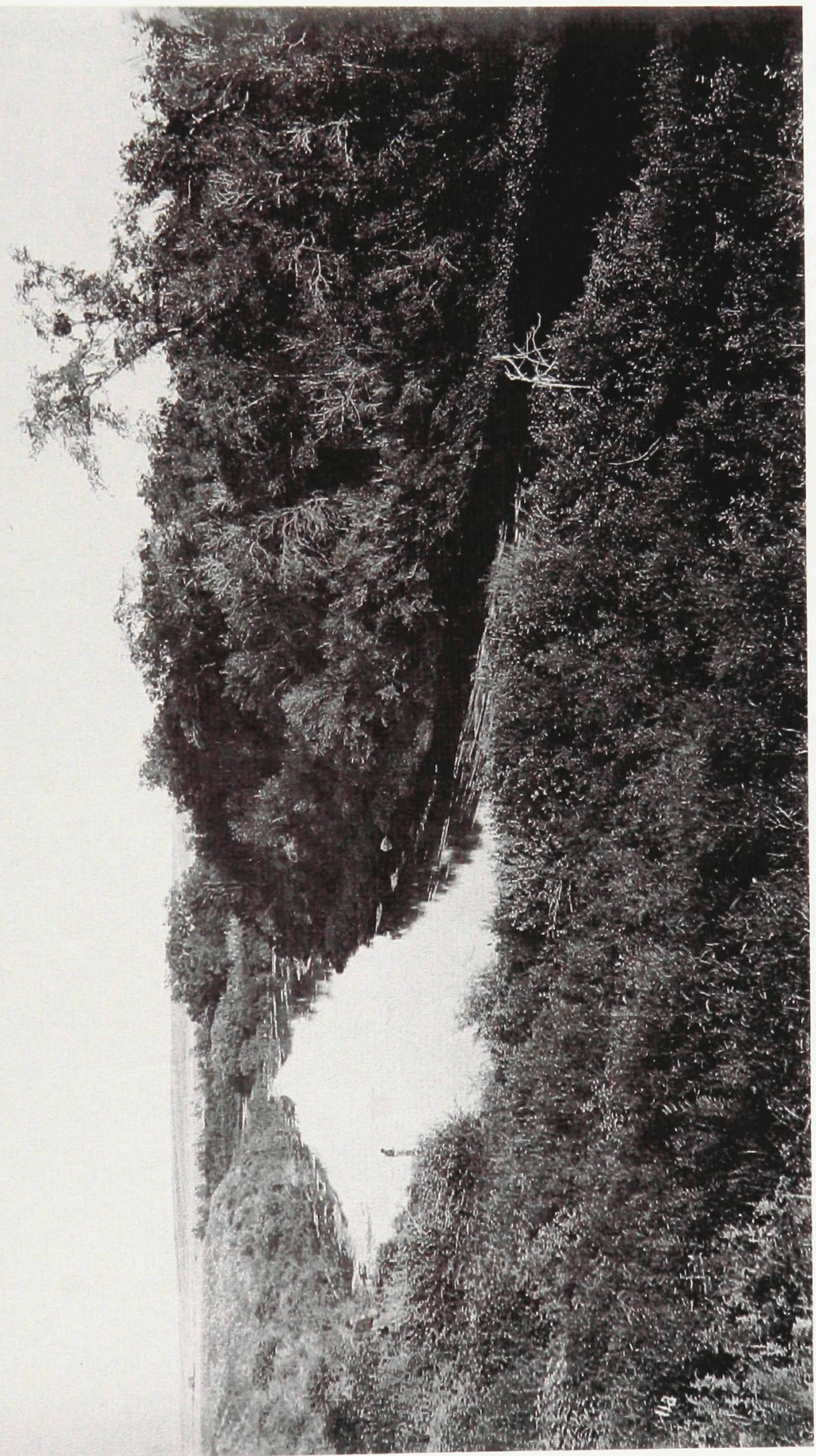

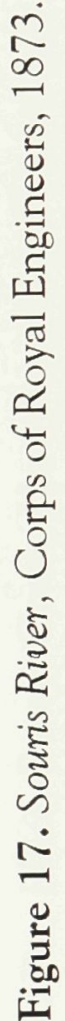






告 


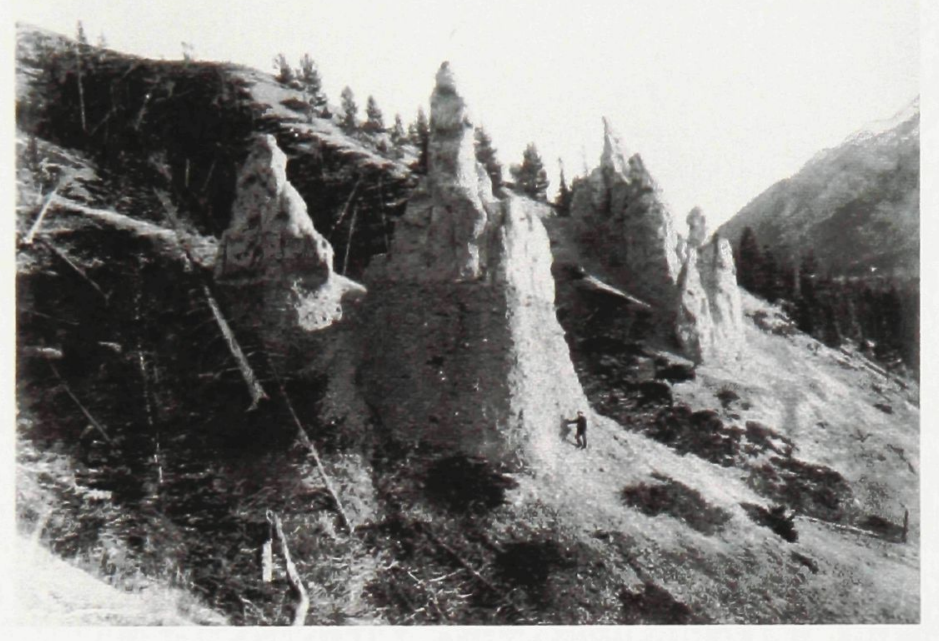

Figure 19. The Hoodoos, Natural Monuments, Banff, William Hanson Boorne, undated [1885-89]. 

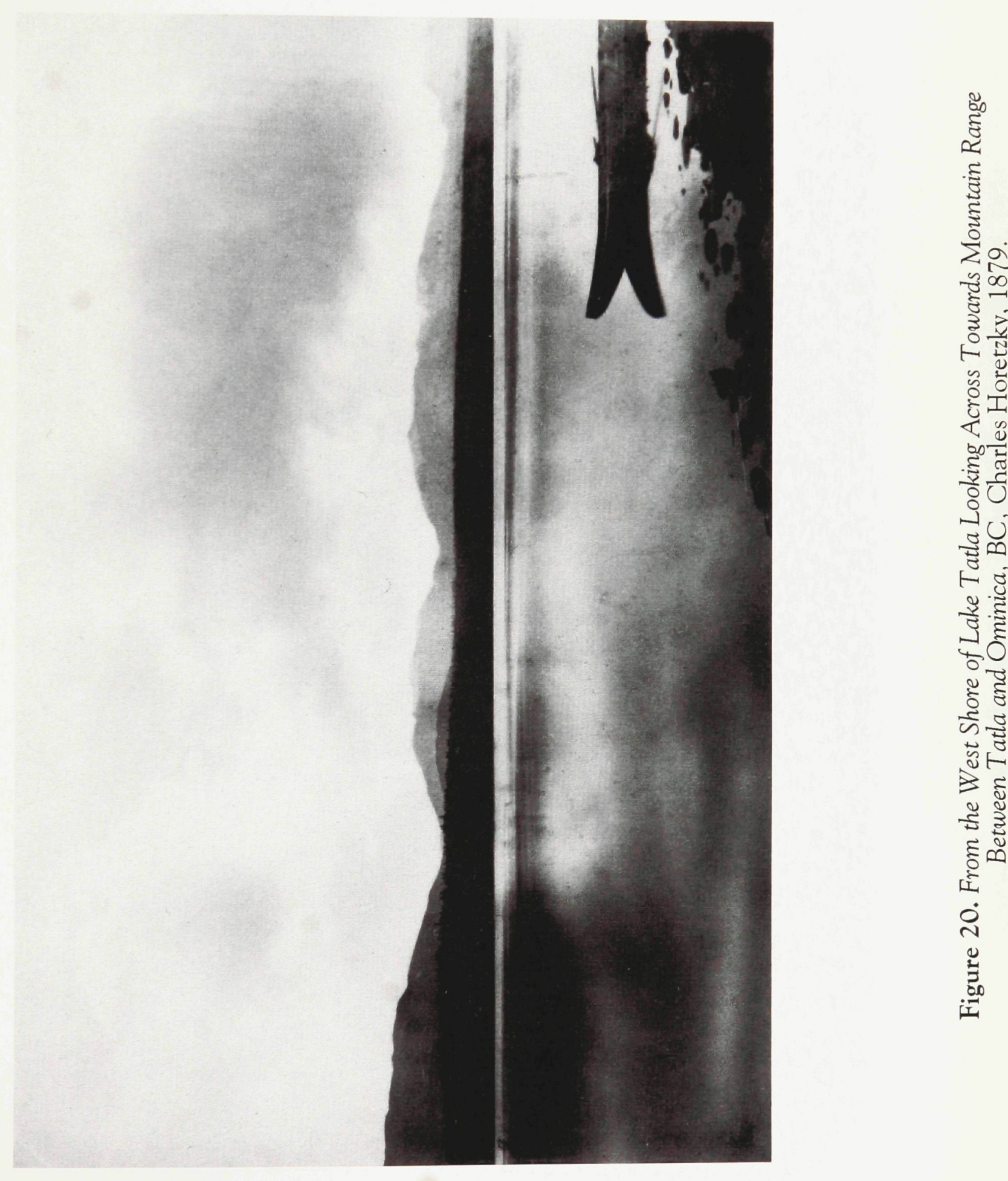


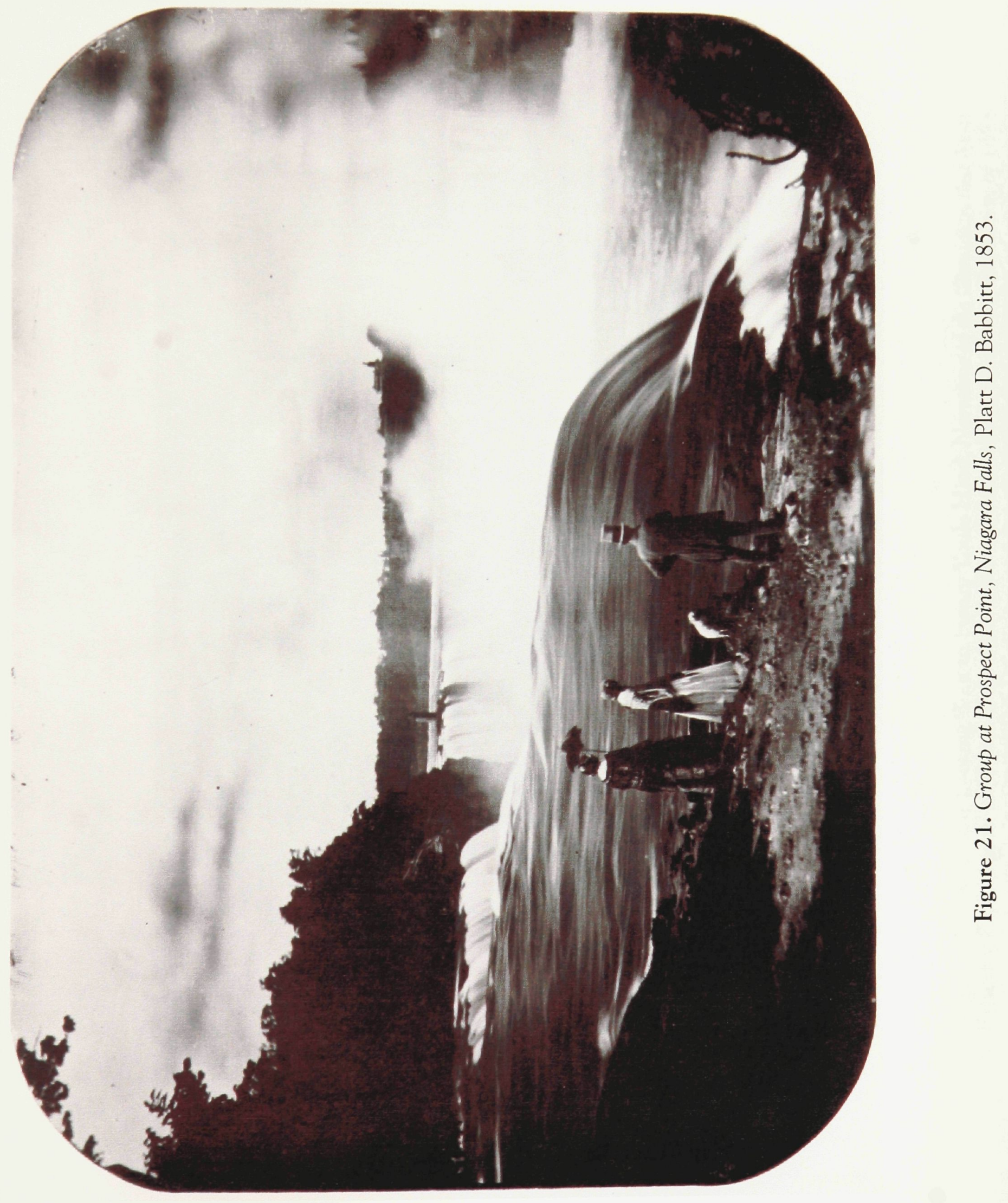











\section{Bibliography}

\section{Photographs}

All the following photographic collections can be found in the National Archives of Canada:

- Arthur Nonus Birch Collection

- Sir Sandford Fleming Collection

- Humphrey Lloyd Hime Collection

- Ken and Jenny Jacobson Collection

- North American Boundary Commission Collection

\section{Archival Materials}

National Archives of Canada. Humphrey Lloyd Hime Papers. Manuscript Group 24, H 87.

National Archives of Canada. Provincial Secretary's Office Canada West. Record Group 5, C 1, Vols.578-579, No. 907.

National Archives of Canada. Walter Butler Cheadle Papers. Manuscript Group 24, H 40, Vol.1, Reel C-6824.

\section{Newspapers}

Gazette. Montreal, 1872.

Globe. Toronto, 1854 and 1856.

\section{Articles and Essays: Nineteenth Century}

Baudelaire, Charles. "The Salon of 1859." Reprinted in Selected Writings on Art and Artists [of] Baudelaire. Patrick Edward Charvet, ed. Harmondworth: Penguin, 1972.

Blanchard, Jerrold. "The Colonies as Food Stores for Great Britain." Discussion of Colonial Questions: Reports of the Proceedings of a Conference Held at Westminster Palace July 19 to 21, 1871. London: Strahunt and Co. Publishers, 1872. 
Charlton, John. "Canada and Imperialism." [Unknown Title]. N.p.: 1900.

Eastlake, Lady Elizabeth. "Photography." Quarterly Review (1857). Reprinted in Classic Essays on Photography. Alan Trachtenberg, ed. New Haven: Leete's Island Books, 1980.

Parkin, George R. "The Geographical Unity of the British Empire." The Scottish Geographical Magazine (1894): 225-242.

\section{Articles and Essays: Secondary Source}

Bell, Keith. "Representing the Prairies: Private and Commercial Photography in Western Canada 1880-1980." Thirteen Essays on Photography. Ottawa: Canadian Museum of Contemporary Photography, 1990.

Berger, Carl. "The True North Strong and Free." Interpreting Canada's Past. Volume II: After Confederation. J.M. Bumsted, ed. Toronto: Oxford University Press, 1986.

Birrell, Andrew J. "The Early Years, 1839-1885." Private Realms of Light: Amateur Photography in Canada, 1839-1940. Lilly Koltun, ed. Markham: Fitzhenry \& Whiteside, 1984.

"Fortunes of a Misfit: Charles Horetzky." Alberta Historical Review, 19.1 (Winter 1971): 9-25.

. "The North America Boundary Commission: Three Photographic Expeditions, 1872-74." History of Photography, 20.2 (Summer 1996): 113-121.

- "Survey Photography in British Columbia, 1858-1900." BC Studies, 52 (Winter 1981-82): 39-60.

Bright, Deborah. "Of Mother Nature and Marlboro Men: An Inquiry into the Cultural Meanings of Landscape Photography." The Contest of Meaning: Critical Histories of Photography. Richard Bolton, ed. Cambridge: The MIT Press, 1989.

Craik, Kenneth H. "Psychological Reflections on Landscape." Landscape Meaning and Values. Edmund C. Penning-Rowsell et al, eds. London: Allen and Unwin, 1986.

Gallagher, John and Ronald Robinson. "The Imperialism of Free Trade." Economic History Review. 2nd ser. 6 (1953): 1-15. 
Jackson, J.B. "The Vernacular Landscape." Landscape Meaning and Values. Edmund C. Penning-Rowsell et al, eds. London: Allen and Unwin, 1986.

Levere, Trevor H. "The British Association Goes West: Montreal 1884." Transactions of the Royal Society of Canada, 4th ser., vol.20 (1982): 489-497.

MacLaren, Ian S. "Aesthetic Mappings of the West by the Palliser and Hind Survey Expeditions, 1857-1859." Studies in Canadian Literature 10.1-2 (1985): 24-52.

Murray, Jeffrey S. "The Map-Makers: Filling in the Blanks in Western America. The Beaver (Feb./Mar. 1989): 14-27.

Ryan, James R. "Imperial Landscapes: Photography, Geography and British Overseas Exploration, 1858-1872." Geography and Imperialism 1820-1940. Morag Bell et al, eds. Manchester: Manchester University Press, 1995.

Schwartz, Joan M. "The Geography Lesson: Photographs and the Construction of Imaginative Geographies." Journal of Historical Geography, 22.1 (January 1996): 16-45.

Allan Sekula. "On the Invention of Photographic Meaning." Thinking Photography. Victor Burgin, ed. Houdmills: Macmillan Press Ltd., 1982.

\section{Books: Nineteenth Century}

Bede, Cuthbert. Photographic Pleasures. London: T. McLean, 1855.

Butler, William Francis. The Great Lone Land: A Narrative of Travel and Adventure in the North-West of America. London: Low \& Searle, 1872.

Canada. Parliament. Legislative Assembly. Report on the Exploration of the Country Between Lake Superior and the Red River Settlement. Toronto: Lovell, 1858.

Carmichael-Smyth, Robert. A Letter to the Right Honourable Earl Grey on the Subjects of Transportation and Emigration, as Connected with an Imperial Railway Communication Between the Atlantic and Pacific. London: W.P. Metchim, 1850.

Corbett, G.O. Notes on Rupert's Land: Its History and Resources, Enclosed with a Letter to His Grace the Duke of Buckingham, Secretary of State for the Colonies. N.p.: 1868.

Grant, George M. Ocean to Ocean: Sandford Fleming's Expedition Through Canada in 1872. Rev. ed. Rutland: Charles E. Tuttle Company, Inc., 1873. 
Griswell, William Parr. The Growth and Administration of the British Colonies, 1837-1897. London: Blackie \& Son, Limited, 1898.

Hind, Henry Youle. Narrative of the Canadian Red River Exploring Expedition of 1857 and of the Assiniboine and Saskatchewan Exploring Expedition of 1858. 2 vols. London: Longman, Green, Longman, and Roberts, 1860.

Hortezky, Charles. Canada on the Pacific: Being an Account of a Journey from Edmonton to the Pacific by the Peace River Valley, and of a Winter Voyage Along the Western Coast of the Dominion, with Remarks on the Physical Features of the Pacific Railway Route and Notices of the Indian Tribes of British Columbia. Montreal: Dawson Brothers, 1874.

Some Startling Facts Relating to the Canadian Pacific Railway and the North-West Lands, Also a Brief Discussion Regarding the Route, the Western Terminus and the Lands for Settlement. Ottawa: Free Press, 1880.

Howe, Joseph. Speech of the Hon. Joseph Howe, Provincial Secretary of Nova Scotia, on the Importance and Values to Great Britain of Her North American Colonies. London: Trewlawney Saunders, 1857.

Lambton, John George, Earl of Durham. Report on the Affairs of British North America. London: n.p., 1839.

Morris, Alexander. Nova Britannia: Our New Canadian Dominion Foreshadowed. Toronto: Hunter, Rose, \& Co., 1884.

Palliser, John. The Papers of Palliser Expedition 1857-1869. Irene M. Spry, ed. and introd. Publications of the Champlain Society 44. Toronto: The Champlain Society, 1968.

Percy, Ford. Selected List of British Parliamentary Papers. Rev. ed. Shannon: Irish University Press, 1969.

Robinson, Henry Peach. Pictorial Effect in Photography: Being Hints on Composition and Chiaroscuro for Photographers. London: Piper and Carter, 1869.

Selwyn, Alfred R. C. Descriptive Sketch of the Physical Geography and Geology of the Dominion of Canada. Montreal: Dawson Brothers, 1884.

Smyth, J.C. Reflections Upon the Value of the British West Indian Colonies and the British North American Provinces. London: C. Roworth, Bell-Yard, Temple-Bar, 1826. 
Synge, Millington Henry. Great Britain, One Empire: On the Union of the Dominions of Great Britain by Intercommunication with the Pacific and the East Via British North America with Suggestions for the Profitable Colonization of the Wealthy Territory. London: J.W. Parker, 1852.

West, John. Substance of a Journal During a Residence at Red River Colony, British North America. London: Seely, 1824.

Wilson, Charles. Mapping the Frontier: Charles Wilson's Diary of the Survey of the 49th Parallel, 1858-1862. George F.G. Stanley, ed. Toronto: Macmillan of Canada, 1970.

\section{Books: Secondary Source}

Alpers, Svetlana. The Art of Describing Dutch Art in the Seventeenth Century. Chicago: Chicago University Press, 1983.

Barrell, John. The Dark Side of the Landscape: The Rural Poor in English Painting 17301840. Cambridge: Cambridge University Press, 1980.

Barthes, Roland. Camera Lucida: Reflections on Photography. Trans. by Richard Howard. New York: Hill and Wang, 1981.

Bell, Morag, Robin Butlin, and Michael Heffernan, eds. Geography and Imperialism 18201940. Manchester: Manchester University Press, 1995.

Berger, Carl. The Sense of Power: Studies in the Ideas of Canadian Imperialism 1867-1914. Toronto: The Copp Clark Publishing Company, 1969.

Berger, John. Ways of Seeing. London: Penguin Books, 1972.

Bermingham, Ann. Landscape and Ideology: The English Rustic Tradition, 1740-1860. Berkeley: University of California Press, 1986.

Bhabha, Homi K. The Location of Culture. London: Routledge, 1994.

Birrell, Andrew J. Benjamin Baltzly: Photographs and Journal of an Expedition Through British Columbia, 1871. Toronto: Coach House Press, 1978.

Into the Silent Land: Survey Photography in the Canadian West, 1858-1900.

Ottawa: Information Canada, 1975. 
Boyanoski, Christine. Staffage to Centre Stage: The Figure in Canadian Art. Toronto: The Art Gallery of Ontario, 1989.

Bryant, Christopher G.A. Positivism in Social Theory and Research. London: Macmillan Publishers Ltd., 1985.

Bunnell, Peter C. A Photographic Vision: Pictorial Photography, 1889-1923. Salt Lake City: Peregrine Smith, Inc., 1980.

Burgin, Victor, ed. Thinking Photography. Houdmills: Macmillan Press Ltd., 1982.

Corey, Melinda and George Ochoa. The Encyclopedia of the Victorian World. New York: Henry Holt and Company, 1996.

Crandell, Gina. Nature Pictorialized: "The View" in Landscape History. Baltimore: The Johns Hopkins University Press, 1993.

Davis, Richard C., ed. Rupert's Land: A Cultural Tapestry. Waterloo: Wilfred Laurier University Press, 1988.

Duncan, James and David Ley, eds. Place/Culture/Representation. London: Routledge, 1993.

Egerton, Hugh E. A Short History of British Colonial Policy, 1606-1909. 12th ed. London: Methuen, 1950.

Eldridge, C.C. Victorian Imperialism. London: Hodder and Stoughton, 1978.

Fischer, Eric, Robert D. Campell, and Eldon S. Miller. A Question of Place: The Development of Geographic Thought. Arlington: R.W. Beatty, Ltd., 1967.

Geller, Peter G. "Northern Exposures: Photographic and Filmic Representations of the Canadian North, 1920-1945." Ph.D. diss., Carleton University, 1995.

Green-Lewis, Jennifer. Framing the Victorians: Photography and the Culture of Realism. Ithaca: Cornell University Press, 1996.

Greenhill, Ralph. Early Photography in Canada. Toronto: Oxford University Press, 1965.

Greenhill, Ralph and Andrew J. Birrell. Canadian Photography, 1839-1920. Toronto: Coach House Press, 1979. 
Hales, Peter Bacon William Henry Jackson and the Transformation of the American Landscape. Philadelphia: Temple University Press, 1988.

Hill, Douglas. The Opening of the Canadian West: Where the Strong Men Gathered. New York: The John Day Company, 1967.

Huyda, Richard J. Camera in the Interior: 1858. Toronto: Coach House Press, 1975.

Jackson, Christopher E. With Lens and Brush: Images of the Western Canadian Landscape 1845-1890. Calgary: Glenbow Museum, 1989.

Javorski, Mary. The Canadian West Discovered: An Exhibition of Printed Maps from the Sixteenth to Twentieth Century. Calgary: Glenbow Museum, 1983.

Jussim, Estelle and Elizabeth Lindquist-Cock. Landscape as Photograph. New Haven: Yale University Press, 1985.

Karamitsanis, Aphrodite. From Terra Incognita to the Prairie West: A Map Exhibition. Edmonton: Friends of the Geographical Names of Alberta Society and Alberta Culture and Multiculturalism, 1988.

Lemagny, Jean-Claude and André Rouillé. A History of Photography: Social and Cultural Perspectives. Trans. Janet Lloyd. Cambridge: Cambridge University Press, 1987.

Leppert, Richard. Art and the Committed Eye: The Cultural Functions of Imagery. Boulder: Westview Press, Inc., 1996.

Lumsden, Ian G. Early Views of British North America from the Collection of the Beaverbrook Art Gallery. Fredericton: Beaverbrook Art Gallery, 1994.

Lutz, Catherine A. and Jane L. Collins. Reading National Geographic. Chicago: Chicago University Press, 1993.

MacKenzie, John M. Propaganda and Empire: The Manipulation of British Public Opinion, 1880-1940. Manchester: Manchester University Press, 1984.

Meining, D.W. The Interpretation of Ordinary Landscapes. Oxford: Oxford University Press, 1979.

Mitchell, W.J.T., ed. Landscape and Power. Chicago: University of Chicago Press, 1994. 
Naef, Weston J. and James N. Wood. Era of Exploration: The Rise of Landscape Photography in the American West, 1860-1885. New York: The Metropolitan Museum of Art, 1975.

Ostroff, Eugene. Western Views and Eastern Visions. Washington: Smithsonian Institution, 1981.

Owens, Craig. Beyond Recognition, Representation, Power and Culture. Berkeley: University of California Press, 1992.

Owram, Doug. Promise of Eden: The Canadian Expansionist Movement and the Idea of the West 1856-1900. 2nd ed. Toronto: University of Toronto Press, 1992.

Pugh, Simon, ed. Reading Landscape: Country-City-Capital. Manchester: Manchester University Press, 1990.

Rees, Roland. Land of Earth and Sky: Landscape Painting of Western Canada. Saskatoon: Western Producer Prairie Books, 1984.

Ryan, James R. Picturing Empire: Photography and the Visualization of the British Empire. Chicago: University of Chicago Press, 1997.

Said, Edward. Culture and Imperialism. New York: Alfred A. Knopf, 1993.

Schama, Simon. Landscape and Memory. Toronto: Random House of Canada, 1995.

Schwarz, Heinrich. Art and Photography: Forerunners and Influences. Kayton: Gibbs M. Smith, Inc., 1985.

Silversides, Brock V. Waiting for the Light: Early Mountain Photography in British Columbia and Alberta, 1865-1939. Saskatoon: Fifth House Ltd., 1995.

Smith, Neil, and Anne Godlewska, eds. Geography and Empire. Oxford: Blackwell, 1994.

Solkin, David H. Richard Wilson: The Landscape of Reaction. London: The Tate Gallery, 1982.

Solomon-Godeau, Abigail. Photography at the Dock: Essays on Photographic History, Institutions, and Practices. Media \& Society 4. Minneapolis: University of Minneapolis Press, 1991.

Sontag, Susan. On Photography. New York: Fraser, Strauss and Giroux. 1977. 
Stanley, Arline Reilein. Auguste Comte. Boston: Twayne Publishers, 1981.

Stott, William. Documentary Expression and Thirties America. London: Oxford University Press, 1973.

Tagg, John. The Burden of Representation: Essays on Photographies and Histories. Amherst: University of Massachusetts Press, 1988.

Trachtenberg, Alan. Reading American Photographs: Images as History Mathew Brody to Walker Evans. New York: Hill, 1989.

Triggs, Stanley. William Notman: The Stamp of a Studio. Toronto: Coach House Press, 1985.

Urry, John. The Tourist Gaze: Leisure and Travel in Contemporary Societies. London: Sage, 1990.

Weaver, Mike, ed. British Photography in the Nineteenth Century: The Fine Art Tradition. Cambridge: Cambridge University Press, 1989.

Wells, Liz, ed. Photography: A Critical Introduction. London: Routledge, 1997.

Wood, Dennis. The Power of Maps. New York: Guilford Press, 1992.

Zeller, Suzanne. Inventing Canada: Early Victorian Science and the Idea of a Transcontinental Nation. Toronto: University of Toronto Press, 1987.

Zerubavel, Evitar. Terra Cognita: The Mental Discovery of America. New Brunswick: Rutgers University Press, 1992. 